OBSERVED AND SIMULATED DISTRIBUTION OF SELECTED HERBICIDES IN SILTY LOAM, SANDY LOAM, AND CLAY SOIL PROFILES NEAR TOPEKA, KANSAS, 1986-88

By Charles A. Perry

U.S. GEOLOGICAL SURVEY

Water-Resources Investigations Report 91-4017

Prepared in cooperation with the KANSAS DEPARTMENT OF HEALTH AND ENVIRONMENT

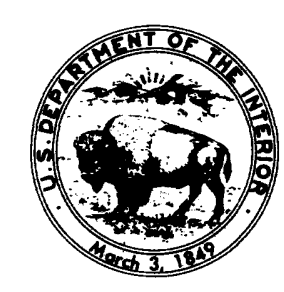

Lawrence, Kansas

1991 


\section{U.S. DEPARTMENT OF THE INTERIOR}

MANUEL LUJAN, JR., Secretary

\section{U.S. GEOLOGICAL SURVEY}

Dallas L. Peck, Director

For additional information write to:

District Chief

U.S. Geological Survey 4821 Quail Crest Place

Lawrence, Kansas 66049
Copies of this report can be purchased from:

U.S. Geological Survey

Books and Open-File Reports

Federal Center, Box 25425

Denver, Colorado 80225 


\section{CONTENTS}

Page

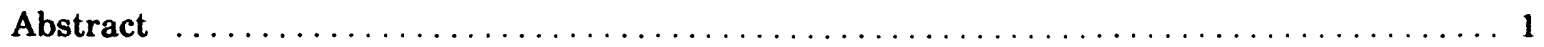

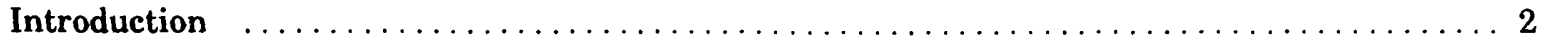

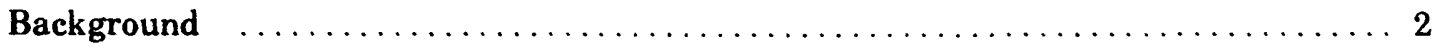

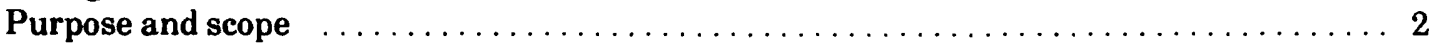

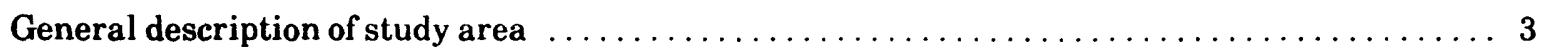

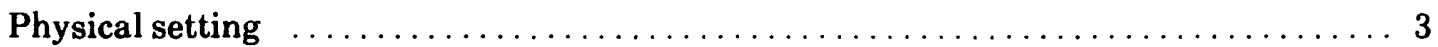

Soil characteristics $\ldots \ldots \ldots \ldots \ldots \ldots \ldots \ldots \ldots \ldots \ldots \ldots \ldots \ldots \ldots \ldots \ldots \ldots \ldots \ldots$

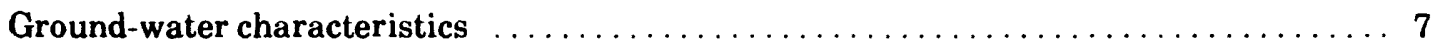

Climate $\quad \ldots \ldots \ldots \ldots \ldots \ldots \ldots \ldots \ldots \ldots \ldots \ldots \ldots \ldots \ldots \ldots \ldots \ldots \ldots$

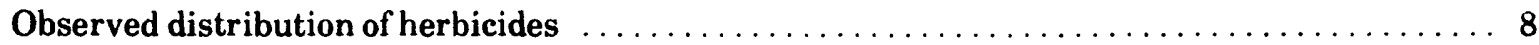

Leaching experiment design $\ldots \ldots \ldots \ldots \ldots \ldots \ldots \ldots \ldots \ldots \ldots \ldots \ldots \ldots \ldots$

Ring lysimeters $\quad \ldots \ldots \ldots \ldots \ldots \ldots \ldots \ldots \ldots \ldots \ldots \ldots \ldots \ldots \ldots \ldots$

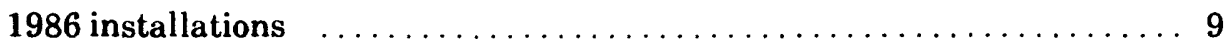

1987 installations $\ldots \ldots \ldots \ldots \ldots \ldots \ldots \ldots \ldots \ldots \ldots \ldots \ldots$

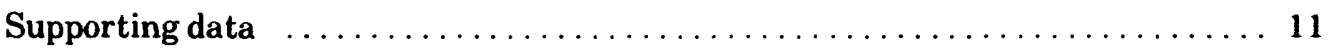

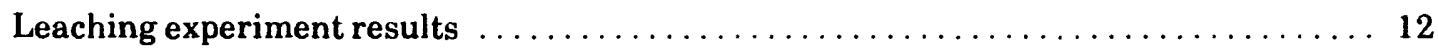

1986 herbicide applications $\ldots \ldots \ldots \ldots \ldots \ldots \ldots \ldots \ldots \ldots \ldots \ldots \ldots \ldots \ldots \ldots$

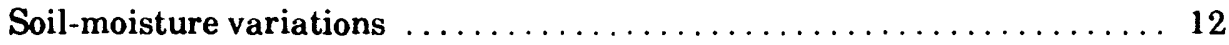

Soil-core herbicide distribution $\ldots \ldots \ldots \ldots \ldots \ldots \ldots \ldots \ldots \ldots \ldots \ldots$

Soil-water atrazine distribution $\ldots \ldots \ldots \ldots \ldots \ldots \ldots \ldots \ldots \ldots \ldots$

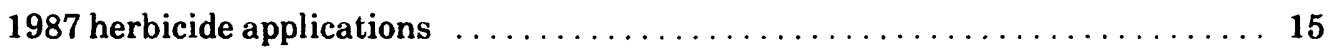

Tracer distribution in soil water $\ldots \ldots \ldots \ldots \ldots \ldots \ldots \ldots \ldots \ldots$

Soil-core atrazine distribution $\ldots \ldots \ldots \ldots \ldots \ldots \ldots \ldots \ldots \ldots \ldots \ldots \ldots \ldots$

Soil-water herbicide distribution $\ldots \ldots \ldots \ldots \ldots \ldots \ldots \ldots \ldots \ldots$

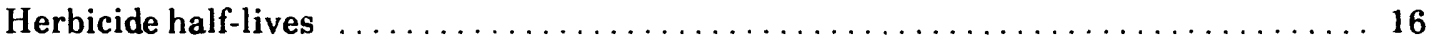

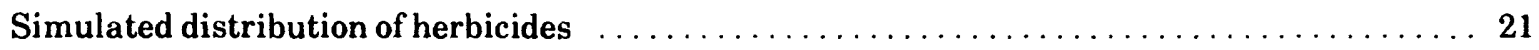

Pesticide Root Zone Model $\ldots \ldots \ldots \ldots \ldots \ldots \ldots \ldots \ldots \ldots \ldots \ldots \ldots \ldots \ldots$

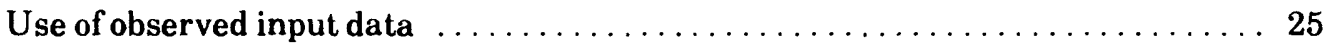

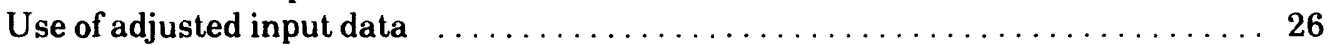

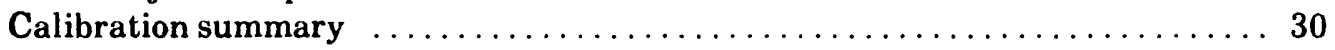

Calibrated-model simulations $\ldots \ldots \ldots \ldots \ldots \ldots \ldots \ldots \ldots \ldots \ldots \ldots \ldots$ 


\section{CONTENTS.-Continued}

Simulated distribution of herbicides--Continued

Calibrated-model simulations--Continued

Conventional atrazine application $\ldots \ldots \ldots \ldots \ldots \ldots \ldots \ldots \ldots \ldots \ldots \ldots \ldots \ldots \ldots$

Atrazine application by chemigation $\ldots \ldots \ldots \ldots \ldots \ldots \ldots \ldots \ldots \ldots \ldots \ldots \ldots$

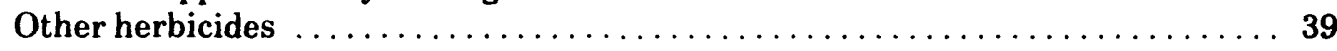

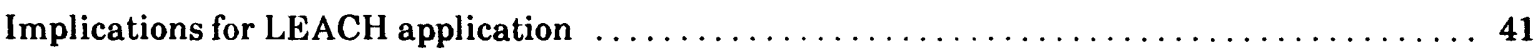

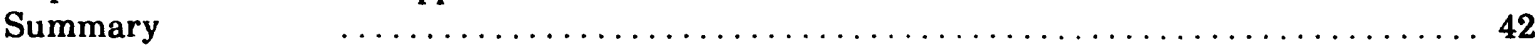

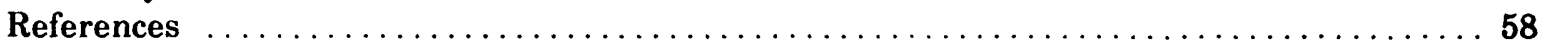

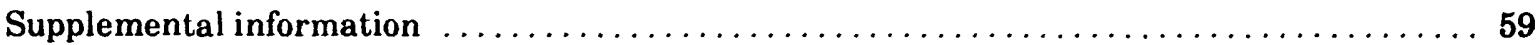

\section{ILLUSTRATIONS}

Figure

1. Maps showing surficial geology, 1967 water table, and soil classifications in study

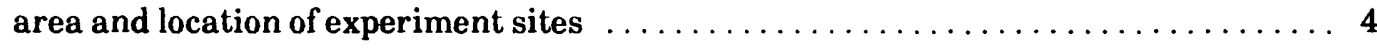

2. Photograph showing installation of ring lysimeter $\ldots \ldots \ldots \ldots \ldots \ldots \ldots \ldots$

3. Diagram showing location of ring lysimeters and accessory equipment at silty loam

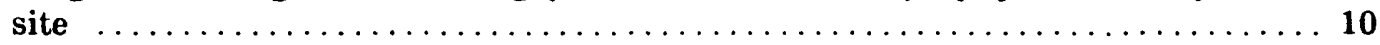

4-8. Graphs showing:

4. Soil-moisture content of silty loam after 3 -inch irrigation in 2 hours on July 24 , 1986

5. Atrazine concentrations in soil water from nonirrigated suction lysimeters in silty

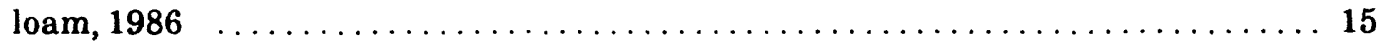

6. Chloride concentrations in soil water from suction lysimeters in silty loam, $1987 \ldots 20$

7. Chloride concentrations in soil water from suction lysimeters in sandy loam, 1987 . 20

8. Chloride concentrations in soil water from suction lysimeters in clay, $1987 \ldots \ldots \ldots 21$

9. Schematic diagram of Pesticide Root Zone Model $\ldots \ldots \ldots \ldots \ldots \ldots \ldots \ldots$

10-24.Graphs showing:

10. Observed and simulated chloride concentrations in soil water at 3- and 6-foot depths

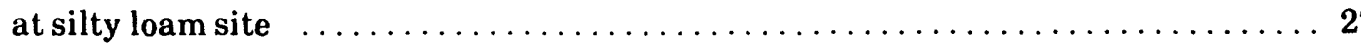

11. Soil particle-size distribution and organic-carbon content for PRZM simulations of silty loam

12. Observed and simulated atrazine concentrations in soil water at 3 - and 6-foot depths at silty loam site 


\section{ILLUSTRATIONS--Continued}

Figure

13. Observed and calibrated atrazine concentrations in soil and soil water at 6-foot depth at sandy loam site

14. Soil particle-size distribution and organic-carbon content for PRZM simulations of sandy loam

15. Soil particle-size distribution and organic-carbon content for PRZM simulations of

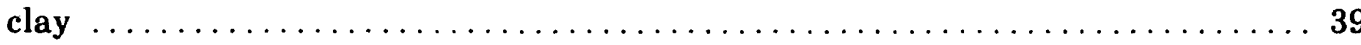

16. Rainfall and atrazine-application amounts and dates for PRZM simulations $\ldots \ldots 40$

17. Rainfall plus irrigation and atrazine-application amounts and dates for 12 -inch chemigation simulations

18. Simulated atrazine concentrations in soil water in silty loam, sandy loam, and clay at 6-foot and 16-foot depths

19. Simulated atrazine concentrations in soil water in silty loam at 6-foot depth with one-half, twice, and near-normal precipitation, and twice-normal atrazine-application rate

20. Simulated atrazine concentrations in soil water in silty loam at 6-foot and 16-foot depths for near-normal precipitation with conventional herbicide application, and 12-inch and 32-inch chemigation applications

21. Simulated atrazine concentrations in soil water in sandy loam at 6-foot and 16-foot depths for near-normal precipitation with conventional herbicide application, and 12-inch and 32-inch chemigation applications

22. Simulated atrazine concentrations in soil water in clay at 6-foot and 16-foot depths for near-normal precipitation with conventional herbicide application, and 12-inch

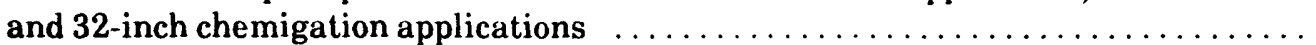

23. Simulated atrazine concentrations in soil water in silty loam, sandy loam, and clay at 6-foot and 16-foot depths for 12-inch chemigation application

24. Simulated alachlor, atrazine, metolachlor, trifluralin, and 2,4-D concentrations in soil water in silty loam at 6-foot depth with near-normal precipitation

\section{TABLES}

1. Soil properties observed at three experiment sites on the Kansas River Valley Experimental Farm near Topeka, Kansas $\ldots \ldots \ldots \ldots \ldots \ldots \ldots \ldots \ldots \ldots \ldots$

2. Atrazine and trifluralin concentrations in composite soil cores from specified depth intervals for ring lysimeters installed in silty loam in 1986 


\section{TABLES--Continued}

Table

3. Atrazine concentrations in soil water from suction lysimeters installed in silty loam in 1986 for nonirrigated and 6 inches of irrigation water $\ldots \ldots \ldots \ldots \ldots \ldots \ldots$

4. Atrazine and chloride concentrations in soil water from suction lysimeters installed at

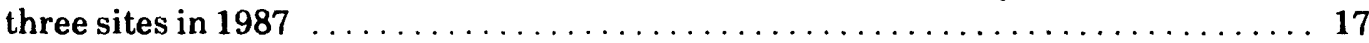

5. Atrazine concentrations in soil cores from ring lysimeters installed at three sites in 1987

6. Alachlor and 2,4-D concentrations in soil water from suction lysimeters installed at three sites in 1987

7. Metolachlor and trifluralin concentrations in soil water from suction lysimeters installed at three sites in 1987

8. Half-lives for alachlor, atrazine, cyanazine, metolachlor, metribuzin, trifluralin, and 2,4-D in soil and saturated material

9. Simulated chloride concentrations in soil water for 1987-88

10. Simulated chloride concentrations in soil water for $1987-88$, with particle-size adjustment

11. Simulated atrazine concentrations in soil cores and soil water for 1987-88, with particle-size adjustment

12. Model-calibrated atrazine concentrations in soil and soil water for $1987-88 \ldots \ldots 36$

13. Atrazine and irrigation-application variations for PRZM simulations $\ldots \ldots \ldots \ldots 6$

14. Application rates, solubility, and estimated half-lives of five herbicides used in

15. Results of leaching simulations 50

16. Root-mean-square computations between observed and simulated chloride and atrazine concentrations in soil water for three soil types and four depths 


\section{CONVERSION FACTORS AND VERTICAL DATUM}

Multiply

inch

foot

yard

mile

acre

quart

pound per acre

inch per foot

gallon per minute

foot squared per day ${ }^{1}$

degree Fahrenheit $\left({ }^{\circ} \mathrm{F}\right)$
By

To obtain

25.4

0.3048

0.9144

1.609

4,047

0.9464

0.112

83.333

0.06309

0.09290

${ }^{\circ} \mathrm{C}=5 / 9\left({ }^{\circ} \mathrm{F}-32\right)$ millimeter

meter

meter

kilometer

square meter

liter

gram per square meter

millimeter per meter

liter per second

meter squared per day

degree Celsius $\left({ }^{\circ} \mathrm{C}\right)$

1 The standard unit for transmissivity (T) is cubic foot per day per square foot times foot of aquifer thickness. This mathematical expression reduces to foot squared per day.

Sea level: In this report, "sea level" refers to the National Geodetic Vertical Datum of 1929--a geodetic datum derived from a general adustment of the first-order level nets of both the United States and Canada, formerly called "Sea Level Datum of 1929." 


\title{
OBSERVED AND SIMULATED DISTRIBUTION OF SELECTED HERBICIDES IN SILTY LOAM, SANDY LOAM, AND CLAY SOIL PROFILES NEAR TOPEKA, KANSAS, 1986-88
}

\author{
By Charles A. Perry
}

\begin{abstract}
Experimental leaching sites, reflecting three soil types, five herbicides, and varied irrigation scheduling, were located at the Kansas River Valley Experimental Farm near Topeka, Kansas. The distribution and movement of five herbicides, alachlor, atrazine, metolachlor, trifluralin, and 2,4-D, were measured in the surface unsaturated zone utilizing ring lysimeters. Measurements and calibrated model simulations determined the extent and potential for herbicide leaching in silty loam, sandy loam, and clay under various conditions. Half-lives of the five herbicides were estimated by analysis of ground-water or soil samples. The Pesticide Root Zone Model, developed by the U.S. Environmental Protection Agency, was calibrated with observed data from the leaching experiments by making adjustments to the input data. These same adjustments are necessary in using the U.S. Environmental Protection Agency's "Leaching Evaluation of Agricultural Chemicals Handbook" for locations in Kansas.
\end{abstract}

In this experiment, two major factors of herbicide movement were eliminated. The factors were surface-water runoff and plant uptake, which are often used as correction factors in most modeling efforts. Their elimination allowed a greater degree of accuracy in determining the movement and persistence of herbicides through the unsaturated soil profile.

Data describing chemical concentrations of the various herbicides and a chloride tracer were collected in conjunction with other environmental data. These data included physical and chemical properties of the soil, soilwater content, rainfall, applied irrigation-water depths, meteorological factors used in estimating potential evapotranspiration, and depth to the water table.

Analysis of soil cores and soil water collected in 1986 indicated no significant differences in atrazine occurrence between the irrigated and nonirrigated plots. Trifluralin concentrations were larger in the nonirrigated plot.

The Pesticide Root Zone Model was best calibrated to the observed data by coding the sand-and-silt fraction as sand, multiplying the observed organic-carbon content by 0.1 , and increasing the half-life of the herbicide with depth and degree of saturation. These adjustments to the input data enabled the model to better simulate herbicide movement through the unsaturated zone to a shallow aquifer. Similar adjustments to the input data must be made before utilizing the Leaching Evaluation of Agricultural Chemicals Handbook.

Simulations of herbicide movement and distribution were made for a 2-year period with the calibrated model under various hypothetical conditions. Simulations were made using the three soil types under one-half normal, normal, and twice-normal annual precipitation, and the simulated pesticide concentration in soil water was monitored at the 6-foot depth. Doubling precipitation increases the peak concentration by one order of magnitude and decreases herbicide traveltime to 70 percent of its previous value. Simulations also were made with normal and twice-normal application rates for atrazine. Doubling the atrazine application rate doubled the peak concentration. Chemigation, the application of herbicides through irrigation water, was simulated by applying one-third of the atrazine at planting, and the remaining twothirds during irrigation. Irrigating or chemigating has the same effect on the peak concentration as a comparable increase in precipitation. Simulations of the four other herbicides showed the effects of different solubility values and half-lives. Although the half-life of metolachlor is about one-half of that for alachlor, its 2.4 times larger solubility resulted in concentrations of metolachlor that were about 1.4 times larger than alachlor at a 6foot depth after 1 year of leaching through a silty loam soil. 


\section{INTRODUCTION}

\section{Background}

The use of herbicides for maximizing crop growth or for rangeland management is common to nearly all farms in Kansas. Their use has been associated with the degradation of groundwater quality in some Kansas aquifers. For example, concentrations of triazine herbicides ranging from 0.10 to about $55 \mu \mathrm{g} / \mathrm{L}$ (micrograms per liter) have been observed in ground water in unconfined aquifers in south-central Kansas (Perry and others, 1988). Continued use of the more commonly used herbicides at current application rates may further degrade aquifer water quality in the future.

Because of the complexities associated with herbicide movement through the soil, herbicide transformation and degradation, and the multitude of combinations of soil, water, and chemicals, the scope of the ground-water contamination problem in Kansas has remained poorly defined. There are many different soil types in Kansas, ranging from impermeable clay to very porous sand. Water available for infiltration varies greatly, with the eastern part of the State receiving more than 40 inches of precipitation annually to only slightly more than 10 inches along the western border (National Oceanic and Atmospheric Administration, 1989); therefore, application of irrigation water is an important factor in herbicide leaching in many areas. Agricultural land use and the associated application of herbicides also vary from shortgrass pastures to intense production of row crops.

It is hypothesized that herbicide residuals and degradation products are building up in the unsaturated zone of the soil profile. As the concentrations increase yearly, the rate at which ground water potentially could be contaminated would be expected to increase also. The extent of the potential contamination of ground water may be much worse than current (1990) data indicate.

The U.S. Environmental Protection Agency began to emphasize the simulation of ground-water contamination by pesticides in 1980 (Enfield and Carsel, 1980). The U.S. Environmental Protection Agency's Environmental Research Laboratory developed the Pesticide Root Zone Model (PRZM) (Carsel and others, 1984), which is a mathematical computer program that simulates the vertical movement of pesticides in the unsaturated zone, within and below the plant root zone and extending to the water table. The model consists of hydrologic and chemical-transport components that simulate runoff, erosion, plant uptake, leaching, decay, foliar washoff, and volatilization of a pesticide. Sensitivity analysis of the model has shown that three factors have a major effect on contaminant movement. These factors are: (1) pesticide half-life, (2) pesticidesoil retardation, and (3) a mount of infiltrated water. All three factors are difficult to estimate accurately. From performance testing at only four locations in the United States, the PRZM was used to simulate pesticide leaching at 19 sites for 25 years. Sparse data were compiled for these 19 sites to estimate model parameters for four major crops--wheat, corn, soybeans, and cotton. From the compilation of information from these 19 sites, the "Leaching Evaluation of Agricultural Chemical Handbook" (LEACH) (Dean and others, 1984) was developed to aid in estimating pesticide movement and decay for varying soil types and climates. To use PRZM or LEACH with any degree of confidence, however, actual field measurements of pesticide leaching and decay need to be made.

In 1986, a 3-year study was initiated to gather information on the leaching of herbicides through silty loam, sandy loam, and clay soils at the Kansas State University Experimental Farm near Topeka, Kansas. The study was conducted by the U.S. Geological Survey, in cooperation with the Kansas Department of Health and Environment, and included the collection of leaching data through the spring of 1988.

\section{Purpose and Scope}

This report describes the distribution of selected herbicides in the unsaturated zone and the use of data collected from 1986-88 to evaluate simulations of leaching by PRZM and LEACH. The scope of the report includes determination of the traveltime of five herbicides (atrazine, alachlor, metolachlor, trifluralin, and 2,4-D) through the unsaturated zones of three soil types ( silty loam, sandy loam, and clay) under varying rainfall amounts and irrigation practices. 
The main objectives of this study were to: (1) document observed movement of herbicides through the unsaturated zone of three soil types and (2) compare the observed movement to simulated movement using the Pesticide Root Zone Model (PRZM) and the "Leaching Evaluation of Agricultural Chemicals Handbook" (LEACH). These objectives involved determination of soil infiltration rates to estimate traveltimes of herbicides through the unsaturated zone for the three soil types and an estimation of herbicide half-lives at various depths. Short-term (monthly) and long-term (yearly) leaching of herbicides were determined for the three soil types under various moisture conditions.

\section{GENERAL DESCRIPTION OF STUDY AREA}

Most of the experimental data for this study were collected at the Kansas River Valley Experimental Farm near Topeka, Kansas. The Kansas River Valley Experimental Farm is one of several Kansas State University Agronomy Farms and Experimental Stations that are located at sites considered representative of large agricultural regions of Kansas. At these sites, research is performed on farming and ranching techniques that are characteristic of each region, such as cropping patterns, pesticide application, and irrigation techniques. Detailed soil analyses are available for most fields, and meticulous pesticide-application records have been maintained for more than two decades at some sites. Pesticides are applied accurately with specially calibrated field sprayers so that initial concentrations can be determined. Another very important aspect of using the farms and stations is that most have complete weather stations permanently installed, which record all data necessary for evapotranspiration calculations. These features of the Agronomy Farms and Experimental Stations make them very beneficial for research of this type.

\section{Physical Setting}

The Kansas River Valley Experimental Farm is located in the Kansas River valley northwest of Topeka in Shawnee County. The valley is approximately 2 miles wide along this reach of the Kansas River. The alluvium adjacent to the river and the Newman and Buck Creek terrace deposits of Pleistocene age are the major geologic units in the valley. The river is on the southern edge of the valley, with the majority of the alluvium to the north (fig. 1). In general, the relative positions of the alluvium and terraces are as follows: alluvium occurs from the river northward to the first distinguishable escarpment toward the valley wall; Newman terrace deposits occur from the first escarpment to the next escarpment or change in soil texture toward the valley wall; and the Buck Creek terrace deposits are adjacent to the valley wall.

The lithologies of the alluvium and the Newman terrace deposits are similar and grade upward from locally derived flat limestone pebbles and boulders on the Pennsylvanian bedrock surface to brownish-gray arkosic sand and gravel in the lower part to fine sand, silt, and silty clay in the upper part. The Buck Creek terrace deposits grade upward from brownishyellow sand, sandy silt, and fine gravel in the lower part to reddish-brown and reddish-tan silt in the upper part (Fader, 1974).

\section{Soil Characteristics}

The Eudora soil series is found in the area of the Experimental Farm. The Eudora series consists of well-drained neutral to moderately alkaline soil that is formed in coarse silty loam or loam alluvium. Eudora soil is friable and easily worked. The Eudora series is naturally fertile and has moderate or large availablemoisture capacity (Abmeyer and Campbell, 1970).

Three experiment sites in the Eudora soil series were chosen to represent the range of permeabilities in the determination of herbicideleaching rates. The three sites were classified generally as the Eudora silty loam at site 1, the Eudora sandy loam at site 2, and the EudoraKimo complex (clay) at site 3 (Abmeyer and Campbell, 1970). Soil properties for each of the three sites are listed in table 1.

The Eudora silty loam characteristic of site 1 is located on the alluvium and Newman 

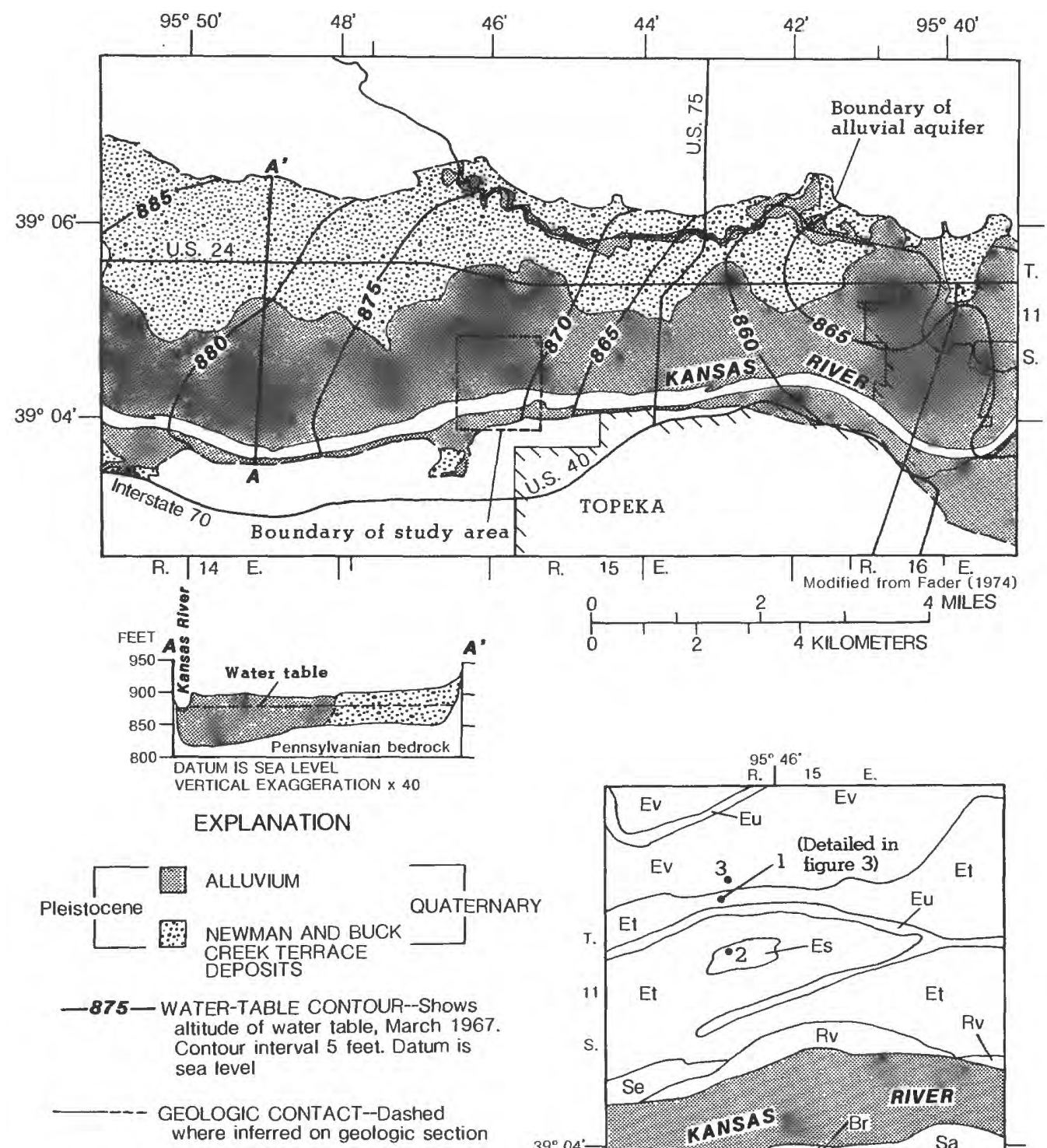

A-A $-\boldsymbol{A}^{\prime}$ TRACE OF GEOLOGIC SECTION

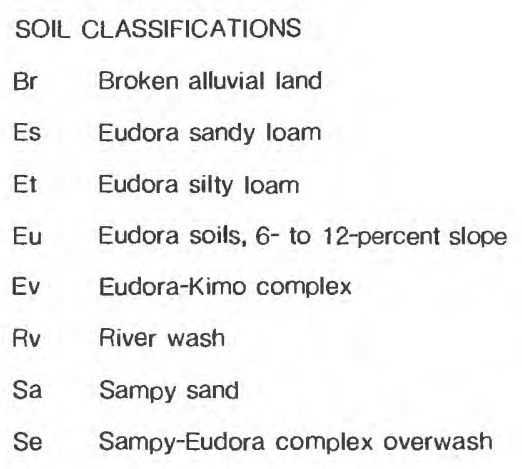

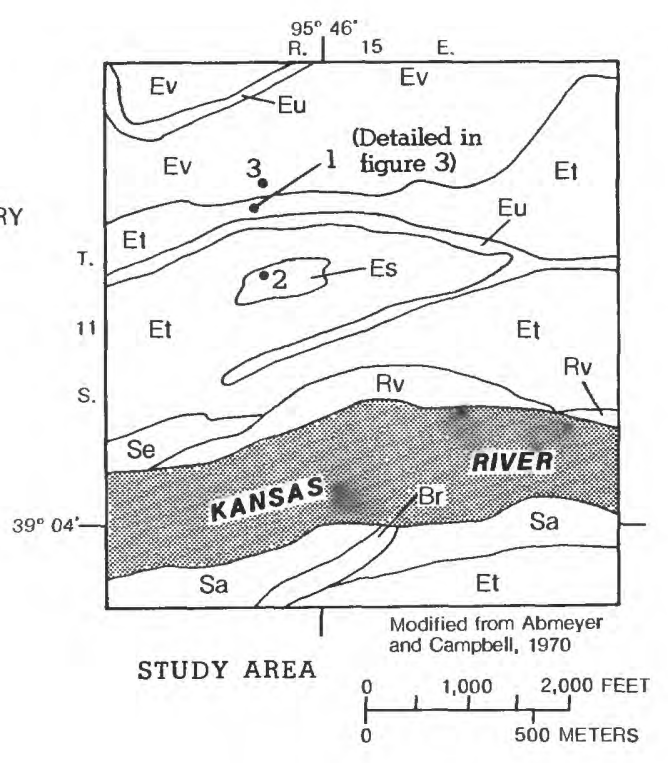

3. EXPERIMENT SITE AND IDENTIFICATION NUMBER

Figure 1. Surficial geology, 1967 water table, and soil classifications in study area and location of experiment sites. 
Table 1. Soil properties observed at three experiment sites on the Kansas River Valley Experimental Farm near Topeka, Kansas

$$
\text { [ --, not determined] }
$$

\begin{tabular}{|c|c|c|c|c|c|c|c|c|}
\hline \multirow{2}{*}{$\begin{array}{l}\text { Experi- } \\
\text { ment } \\
\text { site } \\
\text { (fig. 1) }\end{array}$} & \multirow{2}{*}{$\begin{array}{c}\text { Depth } \\
\text { interval, in } \\
\text { feet }\end{array}$} & \multicolumn{3}{|c|}{$\begin{array}{l}\text { Particle-size distribution, } \\
\text { in percent }\end{array}$} & \multirow{2}{*}{$\begin{array}{c}\text { Bulk } \\
\text { density, } \\
\text { in grams } \\
\text { per cubic } \\
\text { centi- } \\
\text { meter }\end{array}$} & \multirow{2}{*}{$\begin{array}{l}\text { Organic- } \\
\text { carbon } \\
\text { content, in } \\
\text { percent }\end{array}$} & \multirow{2}{*}{$\begin{array}{c}\mathrm{pH}, \text { in } \\
\text { stand- } \\
\text { ard units }\end{array}$} & \multirow{2}{*}{$\begin{array}{l}\text { Perm- } \\
\text { eability, } \\
\text { in inches } \\
\text { per hour }\end{array}$} \\
\hline & & Silt & Sand & Clay & & & & \\
\hline \multirow[t]{15}{*}{1} & $0-0.5$ & 63 & 26 & 11 & 1.53 & 0.99 & 6.8 & 0.20 \\
\hline & $0.5-1.0$ & 60 & 30 & 10 & 1.55 & -- & 7.2 & .14 \\
\hline & $1.0-1.5$ & 61 & 30 & 9 & 1.55 & .69 & 7.3 & .89 \\
\hline & $1.5-2.0$ & 44 & 50 & 6 & 1.56 & -- & 7.3 & - \\
\hline & $2.0-2.5$ & 55 & 40 & 5 & 1.60 & .22 & 7.8 & 3.54 \\
\hline & $2.5-3.0$ & 48 & 31 & 21 & 1.65 & -. & 7.2 & -- \\
\hline & $3.0-3.5$ & 65 & 21 & 14 & 1.40 & .27 & 8.4 & 1.27 \\
\hline & $3.5-4.0$ & 86 & 2 & 12 & 1.33 & -- & 8.2 & -- \\
\hline & $4.0-4.5$ & 66 & 12 & 22 & 1.53 & .60 & 8.1 & .23 \\
\hline & $4.5-5.0$ & 37 & 59 & 4 & 1.54 & -- & 8.6 & - \\
\hline & $5.0-5.5$ & 63 & 32 & 5 & 1.49 & .28 & 8.8 & 4.26 \\
\hline & $5.5-6.0$ & 72 & 21 & 7 & 1.58 & -- & 8.7 & -- \\
\hline & $6.0-6.5$ & 82 & 13 & 5 & 1.55 & .21 & 8.7 & -- \\
\hline & $7.0-7.5$ & 67 & 30 & 3 & 1.70 & - & 8.7 & -- \\
\hline & 9.1-9.7 & 8 & 92 & 0 & 1.70 & - & 8.4 & - \\
\hline \multirow[t]{5}{*}{2} & 0.0 .5 & 40 & 51 & 9 & 1.61 & .43 & 7.1 & -- \\
\hline & $0.5-1.0$ & 35 & 60 & 5 & 1.64 & -- & 8.1 & .20 \\
\hline & $1.0-1.5$ & 82 & 18 & 0 & 1.58 & .14 & 8.7 & -- \\
\hline & $1.5-2.0$ & 93 & 7 & 0 & 1.76 & -- & 8.6 & .20 \\
\hline & $2.0-2.5$ & 60 & 36 & 4 & -- & .21 & 7.7 & -- \\
\hline
\end{tabular}


Table 1. Soil properties observed at the three experiment sites on the Kansas River Valley Experimental Farm near Topeka, Kansas--Continued

\begin{tabular}{|c|c|c|c|c|c|c|c|c|}
\hline \multirow{2}{*}{$\begin{array}{l}\text { Experi- } \\
\text { ment } \\
\text { site } \\
\text { (fig. 1) }\end{array}$} & \multirow{2}{*}{$\begin{array}{l}\text { Depth } \\
\text { interval, } \\
\text { (in feet) }\end{array}$} & \multicolumn{3}{|c|}{$\begin{array}{l}\text { Particle-size distribution, } \\
\text { in percent }\end{array}$} & \multirow{2}{*}{$\begin{array}{c}\text { Bulk } \\
\text { density, } \\
\text { in grams } \\
\text { per cubic } \\
\text { centi- } \\
\text { meter }\end{array}$} & \multirow{2}{*}{$\begin{array}{l}\text { Organic- } \\
\text { carbon } \\
\text { content, in } \\
\text { percent }\end{array}$} & \multirow{2}{*}{$\begin{array}{l}\mathrm{pH}, \text { in } \\
\text { standard } \\
\text { units }\end{array}$} & \multirow{2}{*}{$\begin{array}{l}\text { Perm- } \\
\text { eability, } \\
\text { in inches } \\
\text { per hour }\end{array}$} \\
\hline & & Silt & Sand & Clay & & & & \\
\hline \multirow[t]{8}{*}{2} & $2.5-3.0$ & 65 & 29 & 6 & -- & -- & 8.3 & - \\
\hline & $3.0-3.5$ & 90 & 10 & 0 & 1.48 & 0.26 & 8.6 & -- \\
\hline & $3.5-4.5$ & -- & -- & -- & -- & - & -- & - \\
\hline & $4.5-5.0$ & 24 & 73 & 3 & 1.72 & .16 & 8.7 & 4.38 \\
\hline & $5.0-5.5$ & -- & -- & -- & -- & -- & -- & -- \\
\hline & $5.5-6.0$ & 94 & 6 & 0 & 1.48 & -- & 8.5 & -- \\
\hline & $6.1-6.2$ & 44 & 50 & 6 & -. & -- & 8.6 & -- \\
\hline & $6.5-7.0$ & 62 & 38 & 0 & 1.60 & -- & 8.5 & -- \\
\hline \multirow[t]{13}{*}{3} & $0-0.5$ & 60 & 17 & 23 & 1.76 & .63 & 6.3 & -- \\
\hline & $0.5-1.0$ & 64 & 20 & 16 & 1.72 & -- & 6.7 & .25 \\
\hline & $1.0-1.5$ & 52 & 25 & 23 & 1.78 & - & 6.5 & .04 \\
\hline & $1.5-2.0$ & 61 & 4 & 35 & 1.64 & .21 & 6.9 & -- \\
\hline & $2.0-2.5$ & 66 & 6 & 28 & 1.54 & -- & 7.1 & -- \\
\hline & $2.5-3.0$ & 48 & 0 & 52 & 1.48 & .17 & 7.7 & -- \\
\hline & $3.0-3.5$ & 67 & 3 & 30 & 1.46 & -- & 8.0 & -- \\
\hline & $3.5-4.0$ & 68 & 1 & 31 & 1.50 & .56 & 7.9 & -- \\
\hline & $4.0-4.5$ & 46 & 49 & 5 & 1.42 & -- & 8.6 & -- \\
\hline & $4.5-5.0$ & 72 & 24 & 4 & 1.46 & .18 & 8.7 & - \\
\hline & $5.0-5.5$ & 74 & 20 & 6 & 1.37 & -- & 8.5 & -- \\
\hline & $5.5-6.0$ & 81 & 11 & 8 & 1.43 & -- & 8.6 & - \\
\hline & $6.0-6.5$ & 77 & 12 & 11 & 1.56 & -- & 8.7 & -- \\
\hline
\end{tabular}


terrace deposits throughout the Kansas River valley. This soil is estimated to have a general permeability of between 0.63 and 2.0 inches per hour (Abmeyer and Campbell, 1970). Measured permeability (using an in-situ permeameter) at site 1 ranged from 0.14 to 4.26 inches per hour. Laboratory-measured soil $\mathrm{pH}$ ranged between 6.8 at the surface to 8.8 between 5.0 and 5.5 feet deep. The organic-carbon content varied from 0.99 percent at the surface to 0.21 percent at 6.0 to 6.5 feet.

The Eudora sandy loam (site 2) is estimated to be much more permeable ( 2.0 to 6.3 inches per hour) than the silty loam or the clay (Abmeyer and Campbell, 1970). Measured permeability values varied between 0.20 and 4.38 inches per hour at site 2 . The measured $\mathrm{pH}$ varied from 7.1 at the surface to 8.7 at a depth of about 5.0 feet. The largest organic-carbon content was 0.43 percent at the surface, and the smallest was 0.14 percent at about 1.5 feet.

The Eudora-Kimo complex (site 3 ) consists of intermingled Eudora and Kimo soil on the alluvium and Newman terrace deposits. Site 3 was basically a Kimo soil in the clay lowland range, having an estimated permeability of 0.05 to $\mathbf{0 . 6 3}$ inch per hour, with a large shrink-swell potential (Abmeyer and Campbell, 1970). The measured permeability at experiment site 3 was 0.25 inch per hour for the depth interval 0.5 to 1.0 foot and 0.04 inch per hour for the 1.0- to 1.5foot depth interval.

\section{Ground-Water Characteristics}

Ground water for domestic and stock supplies generally is available throughout the Kansas River valley. Even where the saturated thickness of the alluvium is less than 20 feet, well yields of 500 gallons per minute are possible locally. Where the saturated thickness is 20 to 40 feet, well yields generally range from 300 to 1,000 gallons per minute (Fader, 1974). Transmissivity values in the alluvial aquifer downgradient from the Experimental Farm range from 10,000 to about 50,000 feet squared per day (Fader, 1974). An irrigation well on the Experimental Farm yields an estimated 700 gallons per minute, with a depth to water of approximately 17 feet.
The water is generally very hard; the range of dissolved-solids concentrations is 350 to $1,000 \mathrm{mg} / \mathrm{L}$ (milligrams per liter); calcium and magnesium concentrations range from 170 to $660 \mathrm{mg} / \mathrm{L}$; chloride concentrations average 26 $\mathrm{mg} / \mathrm{L}$; and total iron concentrations average 5.9 $\mathrm{mg} / \mathrm{L}$. Nitrate concentrations in water from the Kansas River alluvium and terrace deposits in Shawnee County range from 1.0 to $20 \mathrm{mg} / \mathrm{L}$ (Fader, 1974). The herbicide, atrazine, was detected in water from the irrigation well on the Experimental Farm at a concentration of 0.70 $\mu \mathrm{g} / \mathrm{L}$ (Perry and others, 1988) in October 1985. However, by summer of 1986 , concentrations decreased to less than the detection level of 0.10 $\mu \mathrm{g} / \mathrm{L}$.

\section{Climate}

The Experimental Farm is near the geographic center of the conterminous United States and has a typical continental climate. Land-surface elevation is about 900 feet above sea level. Characteristics of a continental climate are warm to hot summers, cold winters, moderate surface winds, maximum precipitation in the warm season, and frequent changes in the weather from day to day.

The mean daily temperature at Topeka for 1951-80 for the summer months (June through August) is $76.5{ }^{\circ} \mathrm{F}$, and for the winter months (December through February), it is $30.1{ }^{\circ} \mathrm{F}$. Mean total precipitation for the summer months is 12.87 inches, which is approximately 40 percent of the mean annual precipitation of 33.38 inches (National Oceanic and Atmospheric Administration, 1989). Warm summer temperatures and moderately windy conditions result in an annual free water-surface evaporation of 46 inches (Farnsworth and others, 1982). During the summer, the deficiency between rainfall and evaporation frequently becomes large enough to require irrigation of cropland to maintain optimum production. Intense rainfall during thunderstorms can create a temporary surface-water surplus that either runs off or infiltrates the soil to replenish soil moisture. The bulk of the natural recharge to the local aquifer normally occurs during the late winter and early spring when precipitation exceeds evaporation (Sophocleous and Perry, 1985). 


\section{OBSERVED DISTRIBUTION OF HERBICIDES}

\section{Leaching Experiment Design}

A leaching experiment was designed to determine herbicide concentrations at various depths through the unsaturated zone during 1986-87 for silty loam, sandy loam, and clayey soil types. The assumption that the process of chemical leaching operates in a discontinuous manner in a nonhomogeneous medium, as affected by an impulsive forcing mechanism, was followed in the choice and subsequent revisions of the experiment design.

The leaching experiment was designed to eliminate the effects of runoff and plant uptake, allowing more direct definition of infiltration and unsaturated flow. It is extremely difficult to determine continuous chemical concentrations throughout a runoff period during which concentrations may vary by several orders of magnitude. Plant uptake and plant metabolism of the chemical also are difficult to measure. Many factors, such as age of the plants, their water uptake, and their ability to metabolize the chemical within the cell, are quite variable over time and very difficult to measure. Elimination of runoff and plant uptake in the experiment design should increase the herbicide concentrations, which would allow a greater degree of accuracy in determining the decay rate or half-life of the herbicides investigated.

Surface-water runoff was eliminated by using ring lysimeters that extended 2 to 3 inches above the ground. This design feature allowed all the water that came as precipitation or irrigation to either infiltrate the soil surface or evaporate. The ring lysimeters constrained the applied herbicides laterally through the top 3 feet of the soil profile.

Plant uptake was eliminated simply by allowing no plants to emerge through frequent cultivation (hoeing) of the experiment plots. Besides eliminating plant uptake, cultivation also allowed the maintenance of a fairly constant soil texture at the soil surface. The herbicides chosen for this experiment were not prone to volatilization. Therefore, the herbicide applied was either degraded, transported by the infiltrating water, or sorbed to the material in the soil. A conservative tracer (potassium chloride, $\mathrm{KCl}$ ) was used in the experiment to monitor vertical soil-moisture movement.

This study focused on soil type, waterapplication rate, and physical and chemical properties of the selected herbicides and the effect of these variables have on herbicide movement through the soil. Primary information came from the analysis of soil-water samples collected from the soils of interest at various times through a 2-year period and from certain depths. This information was supplemented by soil-core analyses.

This study required various types of equipment to collect the following data: (1) weather information (air temperature, wind speed, precipitation, humidity, and solar radiation), (2) physical properties of the soil at each site (particle size, bulk density, organiccarbon content, $\mathrm{pH}$, permeability, and moisture content), (3) concentrations of applied herbicides and tracer in soil water, (4) concentrations of the herbicides and tracer in the soil, and (5) conditions of the ground water below the experiment plots. The installation of equipment used in the sampling, the procedures for the collection of representative samples, and the laboratory protocol for the analysis of the samples are presented by Perry and others (in press).

\section{Ring Lysimeters}

Most of this study involved the use of ring lysimeters. These were open-bottomed lysimeters constructed of 1/16-inch steel, rolled into a cylinder and arc-welded at the seam. A welding bead was placed on the bottom edge of the cylinder to facilitate installation. The cylinder was 3 feet in diameter and 3 feet high. It was pressed into the ground by a large hydraulic press, which was anchored into the soil by large earth screws (fig. 2). The press was removed leaving the top of the cylinder extending 2 to 3 inches above the relatively undisturbed soil. The ring was left about a month before any further action was taken to allow the soil to expand to its original volume and contact the inside of the cylinder. Analysis of the soil prior to application of herbicides resulted in no detections. 


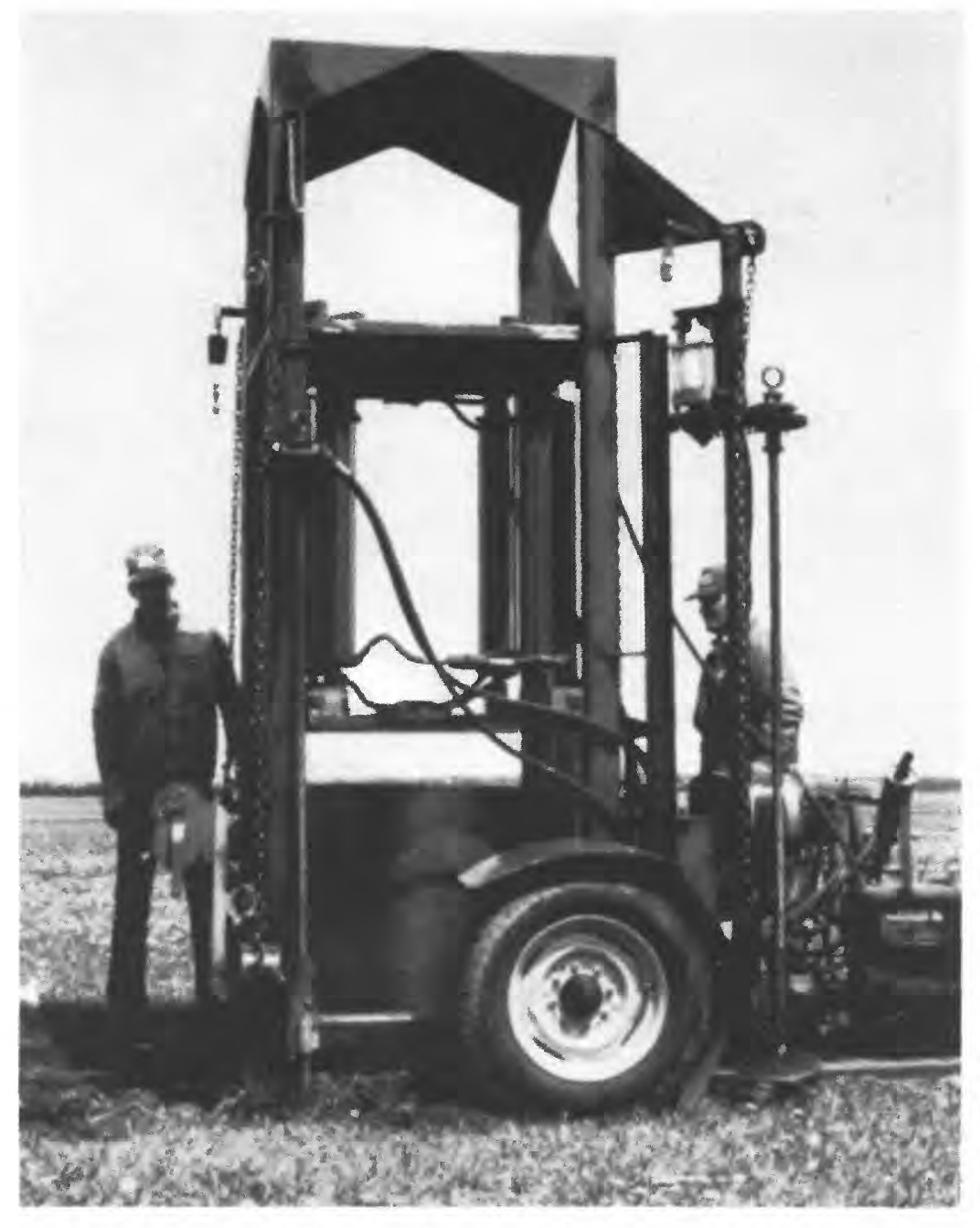

Figure 2. Installation of ring lysimeter.

1986 Installations

In March of 1986, 14 ring lysimeters were installed at the Kansas River Valley Experimental Farm. The location was in a silty loam soil in an area on the farm that had had no pesticide application for at least 10 years (site 1, fig. 1). The rings were arranged so that seven of them could have sprinkler irrigation applied, using water from a nearby irrigation well (fig. 3). The water from the irrigation well was analyzed prior to irrigating in June and July of 1986. No herbicides were detected in the irrigation water at a detection level of $0.10 \mu \mathrm{g} / \mathrm{L}$. The other seven lysimeters received no irrigation water.

Both groups of seven ring lysimeters had the same series of herbicides applied on April 29, 1986 , and were monitored for almost 2 years. The herbicides were incorporated into the soil approximately 1 inch on all ring lysimeters. Six of the seven ring lysimeters in each group had applications of alachlor at 2 quarts per acre, atrazine at 1.5 and 3.0 pounds per acre, metolachlor at 1 quart per acre, trifluralin at 1 quart per acre, and 2,4-D at a rate of 1 quart per acre. The normal application rate for atrazine in the Kansas River valley is about 1.5 pounds per acre. The seventh ring had atrazine applied at a rate of 1.5 pounds per acre. This ring had suction lysimeters installed at depths of $2,3,4$, and 6 feet below the ground surface so that soil-water samples could be obtained to compare with the soil-core data. 


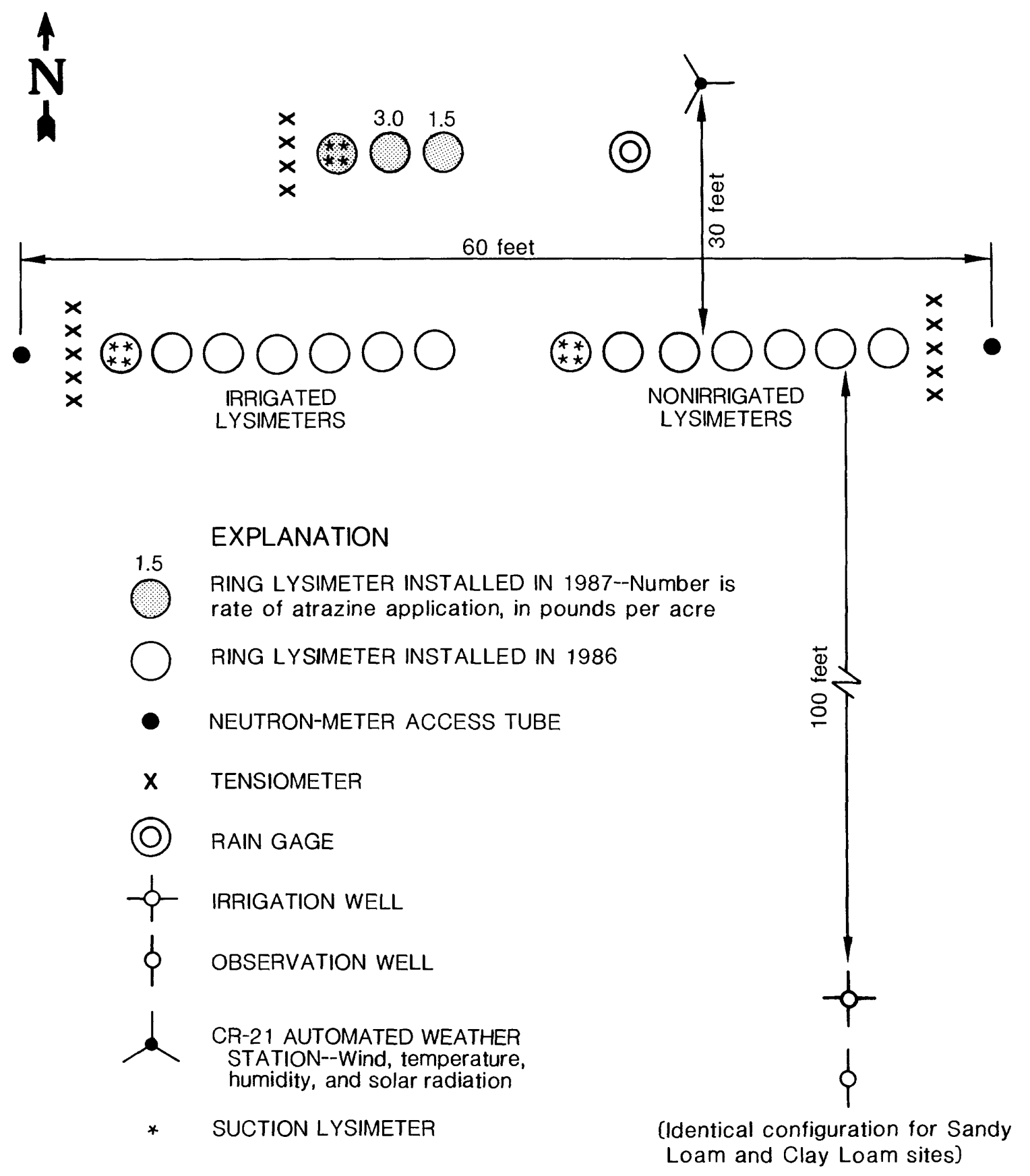

NOT TO SCALE

Figure 3. Location of ring lysimeters and accessory equipment at silty loam site (site 1, fig. 1).

The suction lysimeters consisted of 2-inch polyvinyl-chloride tubes with porous ceramic cups on the lower end. The top of each lysimeter was sealed with a rubber stopper through which a vacuum was created by a vacuum pump connected to silicon tubing that penetrated the rubber stopper. A pinch clamp was used to seal the tubing after the vacuum within the suction lysimeter was generated. Water moved from the soil through the ceramic cup and into the lysimeter if the suction inside the cup was greater than the soil suction. A soil-water sample was obtained after suction was applied to the lysimeter for an interval of several hours to 2 to 3 days. The suction lysimeters were sampled fives times in approximately geometrically increasing time scales from May 1986 to October 1986. 
Soil cores were extracted from the ring lysimeters by means of a hydraulically activated press-core barrel mounted on a trailer. The cores were taken from both the irrigated and nonirrigated sets of ring lysimeters at the same time in an attempt to monitor the effect of different water availability on leaching and persistence of the five herbicides. The holes left after sampling were sealed with bentonite. A total of four cores were taken from each lysimeter during the 2-year period. In July and October of 1986 , core samples were taken at depth intervals of 10 to 16 and 36 to 42 inches. These intervals represent the conditions just below the plow zone (surface to 10 inches) and the layer just below the root zone (surface to 36 inches). In addition to these discrete cores, a composite sample core was taken from the surface to 8 feet to measure the total amount of herbicide within the soil profile. The coring equipment was cleaned thoroughly between each lysimeter sampling to prevent cross contamination. After the cores were extracted, the borehole was filled with bentonite. It was originally thought that none of the selected herbicides would penetrate beyond 8 feet in 1 year, and a mass balance within the ring lysimeter could be performed. Results of the 1986 experiment showed that herbicide movement was much faster than originally anticipated, and consequently, the design was modified in 1987 to obtain a more continuous record of soil-core data.

\section{Installations}

The ring-lysimeter experiment was expanded in 1987 to include two more soil types, sandy loam and clay (sites 2 and 3 , fig. 1). Nine ring lysimeters were installed in the same manner as the ones in 1986. Three ring lysimeters were installed in each of the three soil types, silty loam, sandy loam, and clay. Atrazine was applied on two of the ring lysimeters at each site, one at a rate of 1.5 pounds per acre and the other at 3.0 pounds per acre. The third ring lysimeter had suction lysimeters installed at the same depths as in 1986 (fig. 3). Five herbicides were applied on this third ring, alachlor at 2 quarts per acre, atrazine at 3.0 pounds per acre, metolachlor at 1 quart per acre, trifluralin at 1 quart per acre, and 2,4-D at 1 quart per acre. In addition to the herbicides, potassium chloride $(\mathrm{KCl})$ was applied at a rate of 200 pounds per acre to serve as a conservative tracer. Soil-water samples were collected and analyzed for each of the five herbicides and chloride. Soil cores and soil-water samples were collected from each ring lysimeter as soon as possible after any significant rainfall.

\section{Supporting Data}

Additional environmental data were collected in conjunction with soil and groundwater samples from the experimental sites. These data included: physical properties of the soil, soil-water content, rainfall, applied irrigation-water depths, meteorological factors affecting potential evapotranspiration, and depth to water. This information was used to describe saturated and unsaturated flow from the ground surface to the water table for the duration of the experiment.

The physical properties of the three soils included particle-size and organic-carbon analyses, measurements of soil and soil-water $\mathrm{pH}$, in-situ measurements of soil permeability using the constant-head method, and measurements of soil density. The soil-moisture profiles for each of the sets of ring lysimeters (1986 and 1987) were monitored through a neutron-meter access tube. In addition to neutron-moisture-meter measurements of soil moisture, nests of tensiometers were installed for each set of 1986 and 1987 ring lysimeters at depths of 6 inches, 1, 2, 3, 4, and 6 feet (fig. 3). Neutron-meter and tensiometer readings were taken weekly and after most periods of significant rainfall throughout the growing season.

Rainfall was measured at the fully automated weather station, which was about 30 feet from the farthest ring lysimeter. The weather station measured wind speed and direction, air temperature, relative humidity, and solar radiation. These measurements were used to calculate daily potential evapotranspiration using Penman's equation (Penman, 1948). Irrigation water was measured by an individual manual rain gage located near the center of the 1986 irrigated lysimeters at the silty loam site.

Local ground-water levels were measured in an observation well and in the farm's irrigation well. Because the emphasis of this study was on the unsaturated zone, no 
measurements were made to determine regional ground-water flow. The reader is referred to Fader (1974) for this information.

\section{Leaching Experiment Results}

\section{Herbicide Applications}

The 1986 experiment began on April 28 with the application of the five herbicides onto the 14 ring-lysimeter plots. Periodic hand cultivation was the only farming activity conducted on the plots. Irrigation water was applied twice to the seven irrigated lysimeter rings during the summer of 1986.

\section{Soil-Moisture Variations}

The first irrigation application was on June 26 and totaled approximately 3 inches of water in 2 hours. The second application was on July 24 and was also approximately 3 inches. The response of soil moisture as measured by the neutron meter at the silty loam site (site 1, fig. 1) for the July 24 irrigation is shown in figure 4.
Irrigation water was applied for approximately 2 hours. There was an immediate response of soil moisture throughout the profile to 5 feet. The moisture content of the 1- and 2-foot depths increased immediately, whereas at the 3- and 4foot depths, moisture decreased during the irrigation. After 2 hours of irrigation, soilmoisture content at the 3-and 4-foot depths began to increase. A slight decrease in moisture at the 5-foot depth was detected about 24 hours after irrigation ceased. Less-detailed data for the June 26 irrigation showed a similar response of rapid moisture-content changes through the soil profile.

\section{Soil-Core Herbicide Distribution}

Soil cores were extracted from the ring lysimeters on July 10 and October 8,1986 , on April 23, 1987, and on March 22, 1988, representing a 2-year period of leaching and degradation for the one application of herbicides at site 1. Atrazine and trifluralin were detected in the soil cores and are tabulated in table 2. Trifluralin was still detected after

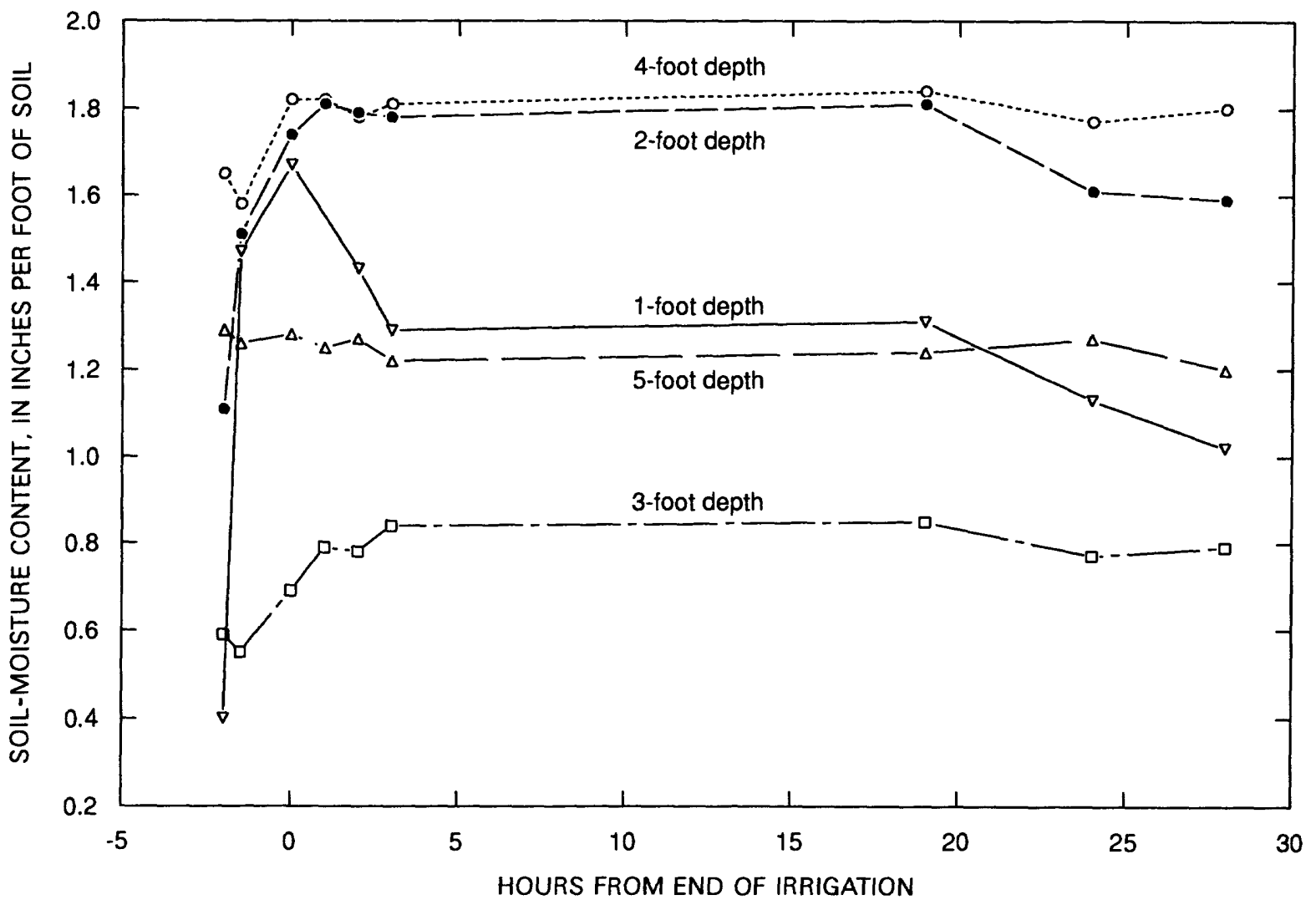

Figure 4. Soil-moisture content of silty loam after 3-inch irrigation in 2 hours on July 24، 1986. 


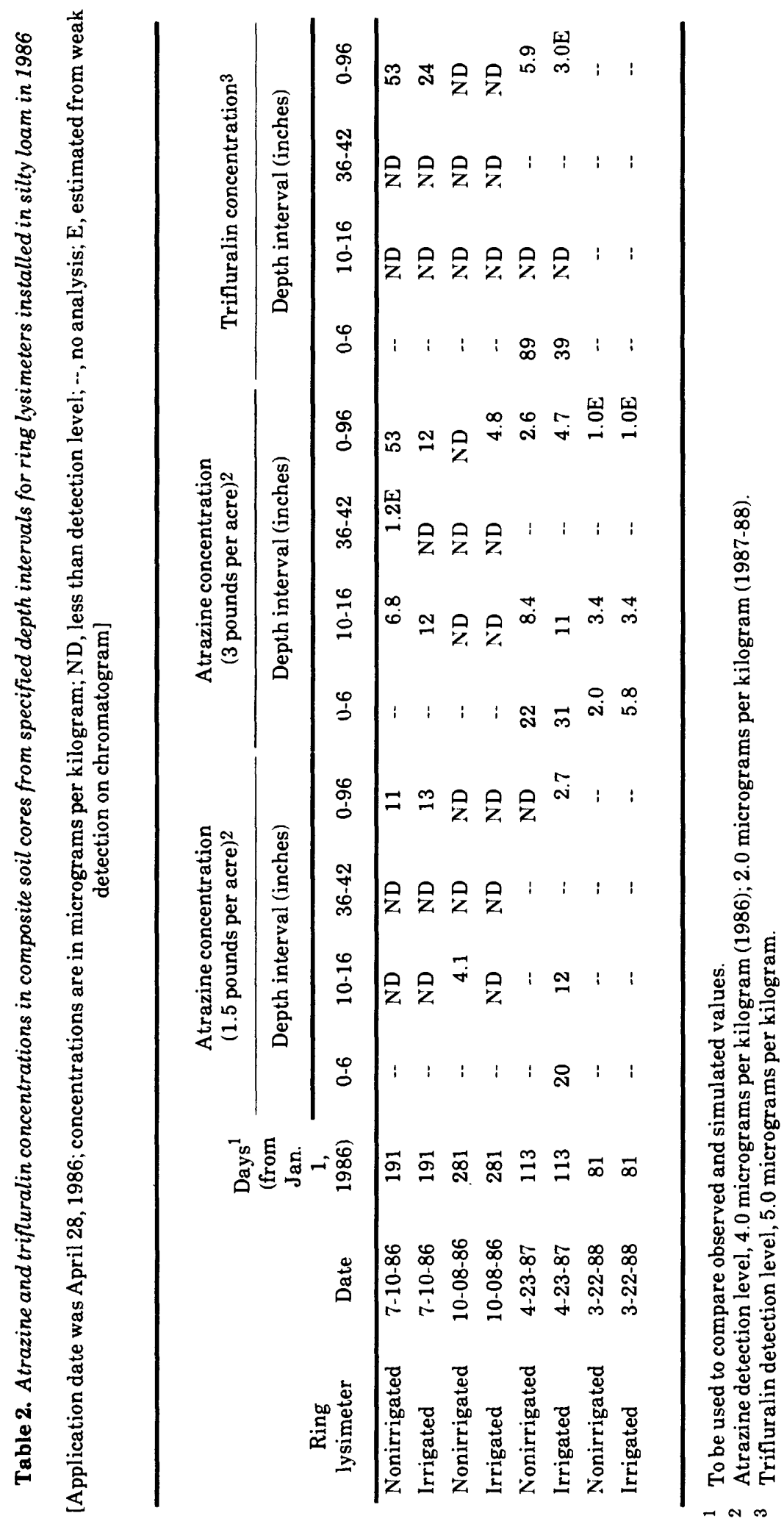


nearly 1 year and atrazine after nearly 2 years. Trifluralin concentrations were larger in the nonirrigated lysimeters. For the other herbicides, soil cores showed no tendency toward larger herbicide concentrations on either the irrigated or nonirrigated plots. Concentrations of alachlor, metolachlor, or 2,4-D were less than the levels of detection for all of these soil cores. The cause of the small concentrations and nondetections may be that rainfall in 1986 came immediately after the herbicide application and totalled 12.47 inches from April 28 to July 12. The greater-than-normal rainfall may have flushed most of the herbicide through the ring lysimeter down to the coarse sand, which is below the silty loam. Composite samples from the surface to 8 feet showed concentrations decreasing for both atrazine and trifluralin as a function of time.

Soil-Water Atrazine Distribution

Soil water was extracted from the suction lysimeters on April 29, May 15, May 23, June 11, July 9, and October 7, 1986, and analyzed for atrazine. These data are listed in table 3. The most striking feature in this data was an apparent pulse of atrazine that moved through the soil profile of the nonirrigated lysimeter, taking 19 days to go between the 3-and 4-foot depths and 28 days to go between the 4- and 6foot depths (fig. 5). These traveltimes were much shorter than expected.

Atrazine moved more slowly through a soil profile than did the chloride tracer probably

Table 3. Atrazine concentrations in soil water from suction lysimeters installed in silty loam in 1986 for nonirrigated and 6 inches of irrigation water

[Application date was April 28, 1986 (ring lysimeters); --, no analysis]

\begin{tabular}{|c|c|c|c|c|c|c|}
\hline \multirow{3}{*}{$\begin{array}{l}\text { Suction } \\
\text { lysimeter }\end{array}$} & \multirow[b]{3}{*}{ Date } & \multirow{3}{*}{$\begin{array}{c}\text { Days }^{1} \\
\text { (from } \\
\text { Jan. 1, } \\
\text { 1986) }\end{array}$} & \multicolumn{4}{|c|}{ Atrazine concentration ${ }^{2}$, in micrograms per liter } \\
\hline & & & \multicolumn{4}{|c|}{ Depth, in feet } \\
\hline & & & 2.0 & 3.0 & 4.0 & 6.0 \\
\hline \multirow[t]{6}{*}{ Nonirrigated } & $4-29-86$ & 119 & -- & - & - & 0.01 \\
\hline & $5-15-86$ & 135 & -- & -- & 0.60 & .10 \\
\hline & $5-23-86$ & 143 & - & 1.3 & .50 & .01 \\
\hline & $6-11-86$ & 162 & 1.2 & .70 & 1.4 & .01 \\
\hline & $7-09-86$ & 190 & .10 & .10 & .70 & 1.2 \\
\hline & $10-07-86$ & 240 & .01 & .01 & .01 & .01 \\
\hline \multirow[t]{6}{*}{ Irrigated } & 4-29-86 & 119 & -- & -- & -- & .01 \\
\hline & $5-15-86$ & 135 & - & -- & .50 & -- \\
\hline & $5-23-86$ & 143 & -- & .90 & .30 & -- \\
\hline & $6-11-86$ & 162 & -- & -- & -- & -- \\
\hline & $7-09-86$ & 190 & 12 & -- & .60 & -- \\
\hline & $10-07-86$ & 240 & .60 & .01 & .01 & .01 \\
\hline
\end{tabular}

1 To be used to compare observed and simulated values.

2 Detection level is 0.01 micrograms per liter. 


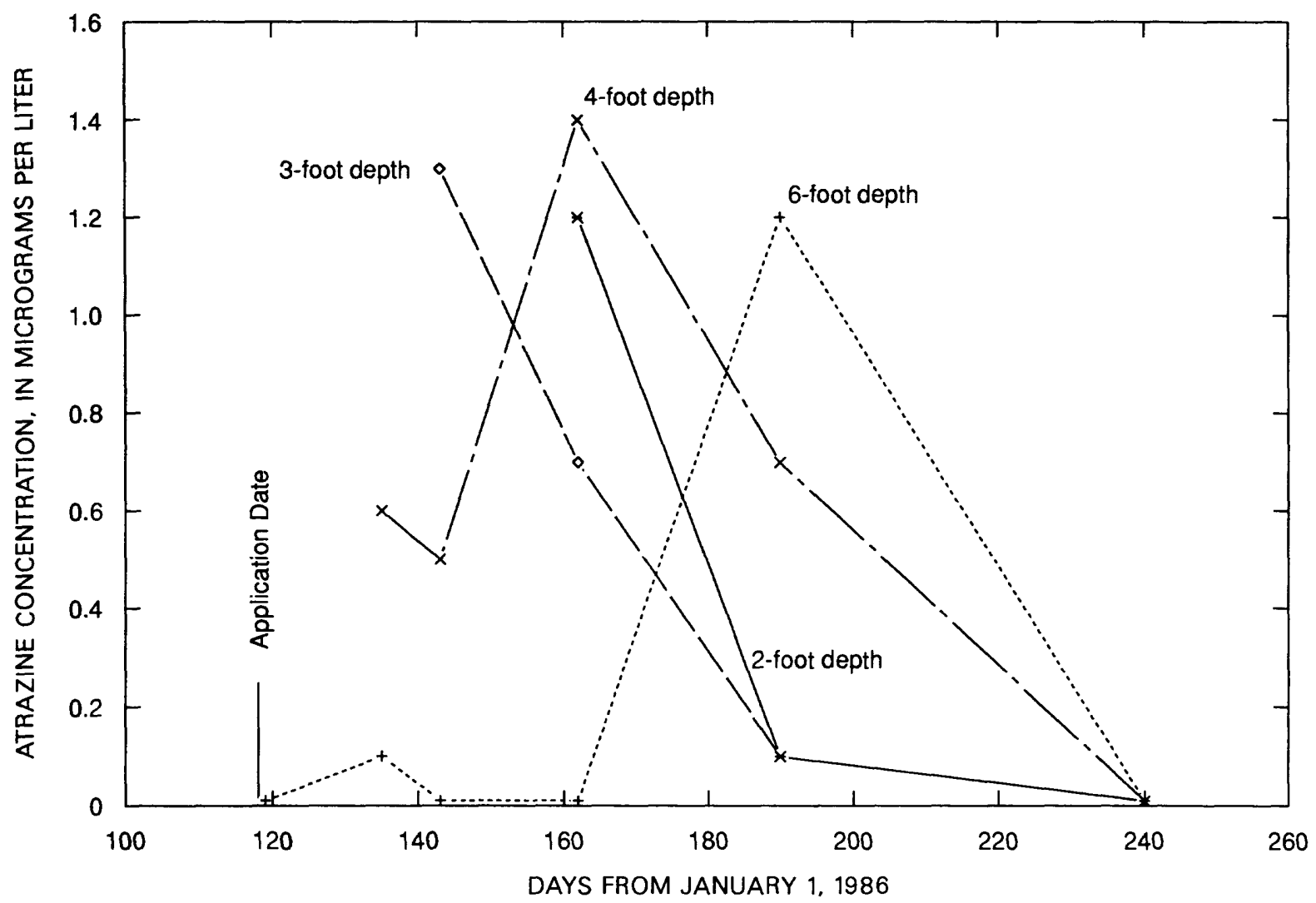

Figure 5. Atrazine concentrations in soil water from nonirrigated suction lysimeters in silty loam, 1986.

because of the adsorption-desorption of the atrazine to soil particles. It is likely that the rainfall in 1986 moved the atrazine through the soil profile so rapidly that the peak concentrations at the 2- and 3-foot depths were missed. Lag time between peak concentrations of atrazine at the 4- and 6-foot depths was approximately 30 days (fig. 5 ).

\section{Herbicide Applications}

After the 1986 field season, it became apparent that the herbicides with larger solubility values and longer half-lives were moving through the soil profile more rapidly than had been expected. The sample scheduling was such that the peak values in herbicide concentrations in the shallow layers were missed. Also, much was learned in the first year of the study concerning the installation of suction lysimeters and the depths at which to take soil cores. The suction lysimeters were installed for the 1987 season using silicon flour around the ceramic cups. This modificaton resulted in more soil water for herbicide analysis, lower detection levels in those samples, and more samples being collected. Soil cores were collected continuously from the surface to 6 feet below land surface. The 1987 soil cores were collected in anticipation of larger concentrations of the herbicides remaining in the top 1-foot of the soil profile.

The 1987 ring lysimeter experiment began on April 29 with the application of alachlor, atrazine, metolachlor, trifluralin, 2,4-D, and the tracer potassium chloride on three sets of ring lysimeters at the silty loam, the sandy loam, and the clay experiment sites. Applications of $\mathbf{1 . 5}$ and 3.0 pounds per acre of atrazine were made on two 1987 lysimeters at each site (see fig. 3). The rates of application of the other herbicides were the same as in 1986. The potassium chloride was applied at a rate of 200 pounds per acre. Soil-core samples were collected at these lysimeters on May 28, June 26, August 10, and October 19, 1987, and March 22, 1988. Soil-water samples were collected May 14 and 28, June 1 and 26, July 21 and 24, August 20 and 24, October 14 and 19, and December 1, 1987, and on March 22 
and 31,1988 . The increased frequency of sampling was an attempt to improve monitoring of the initial movement of the herbicides and tracer. No irrigation water was applied to any of the ring lysimeters. Rainfall for May, June, and the first part of July was about two-thirds that of the same period in 1986. In addition, no rain fell for nearly 1 month after the application of the chemical. Evaporation was rapid during this time, resulting in a moisture deficiency in the uppermost layers. A 2.40-inch rainfall occurred on May 24, but the previously existing moisture deficiency decreased the leaching capacity of the rainfall.

\section{Tracer Distribution in Soil Water}

The soil water was analyzed for chloride concentrations on all but three of the sampling dates for each of the three soil types. These data are listed in table 4. The chloride data provided information on the movement of the soil water through the unsaturated zone for the three soil types. A comparison of traveltimes for chloridetracer concentrations at various depths at the silty loam site for 1987 is shown in figure 6. Lag times between maximum chloride concentrations were considerably longer in the 1987 data, most likely a result of the lesser rainfall during 1987. Lag time of the chloride concentrations for 1987 between the 2 - and 3 -foot depths was 80 days and between the 3- and 4-foot depths, 55 days. No conclusions could be drawn from the 6-foot-depth chloride information.

The response of the sandy loam and clay soil to leaching of the chloride can be seen in the chloride concentrations depicted in figures 7 and 8. Chloride concentrations in the sandy loam show a large peak of about $1,400 \mathrm{mg} / \mathrm{L}$ at the 2 foot depth 29 days after application (fig. 7). A similar response is seen in the 3 -foot chloride concentrations, suggesting that movement between the 2- and 3-foot depths is rapid. Between the 3- and 4-foot depths there was a lag time of 59 days, and between the 4- and 6-foot depths, 99 days. The chloride concentrations observed in the clay soil show no discernable patterns between depths except that concentrations at all levels reached a high point about 150 days after application.

Soil-Core Atrazine Distribution
Soil cores from the ring lysimeters installed in 1987 were analyzed for atrazine only. The results of these analyses are listed in table 5. The concentrations of atrazine found in the soil cores were much larger than expected, most likely a result of no runoff losses or losses to plant uptake. Quality-assurance procedures verified the reported values. Generally, the average atrazine concentrations in all the cores from the rings with 3.0 pounds per acre of applied atrazine were about 2.4 times the average concentrations in the cores from the rings with 1.5 pounds per acre application. These larger concentrations could indicate that herbicide half-lives are longer when large concentrations of herbicide are present in the soil.

\section{Soil-Water Herbicide Distribution}

Soil water from the suction lysimeters were analyzed for alachlor, atrazine, metolachlor, trifluralin, and 2,4-D. The results of the atrazine analyses are listed in table 4 along with the chloride data. Results of the alachlor and 2,4-D analyses are listed in table 6 for comparison, and metolachlor and trifluralin analyses are listed in table 7. 2,4-D was not detected in the first samples and subsequently was eliminated from the remaining analyses.

The concentrations of alachlor in the soil water were much smaller than the atrazine concentrations, a direct result of the shorter halflife of the alachlor in the soil. 2,4-D was not detected in any of the soil-water samples. The very spotty detections of the fairly insoluble trifluralin is probably a result of soil-phase transport of that herbicide through macropores.

\section{Herbicide Half-Lives}

The half-life of a herbicide is the time that must elapse before one-half of an original quantity is transformed into another chemical compound. Various physical, chemical, and biological factors affect the rate of transformation or degradation. Some degradation products can be as toxic as the original compound. The surface layer of soil is usually where the half-life of a herbicide is the shortest. Table 8 lists the herbicides commonly used at the Kansas River Valley Experimental 


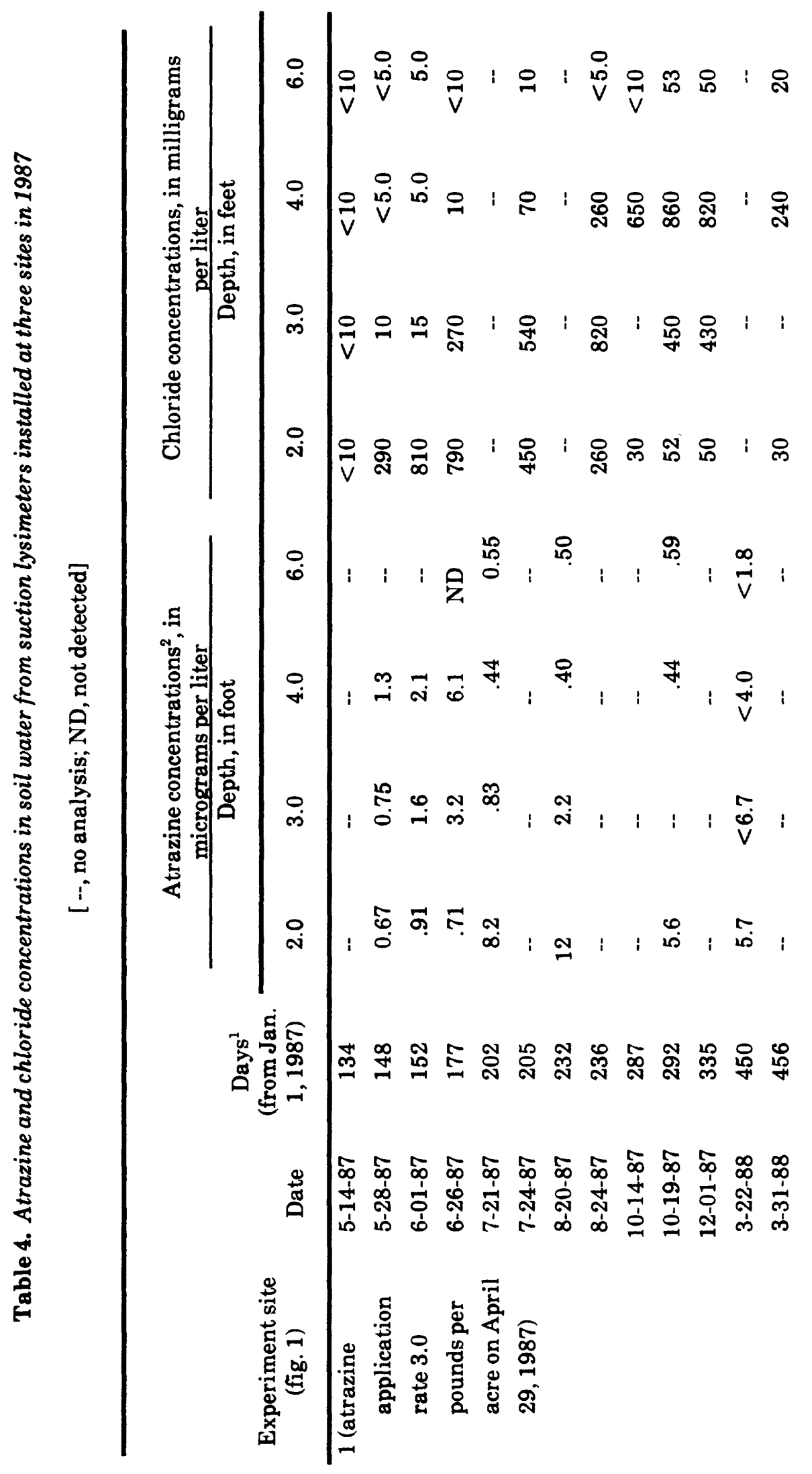




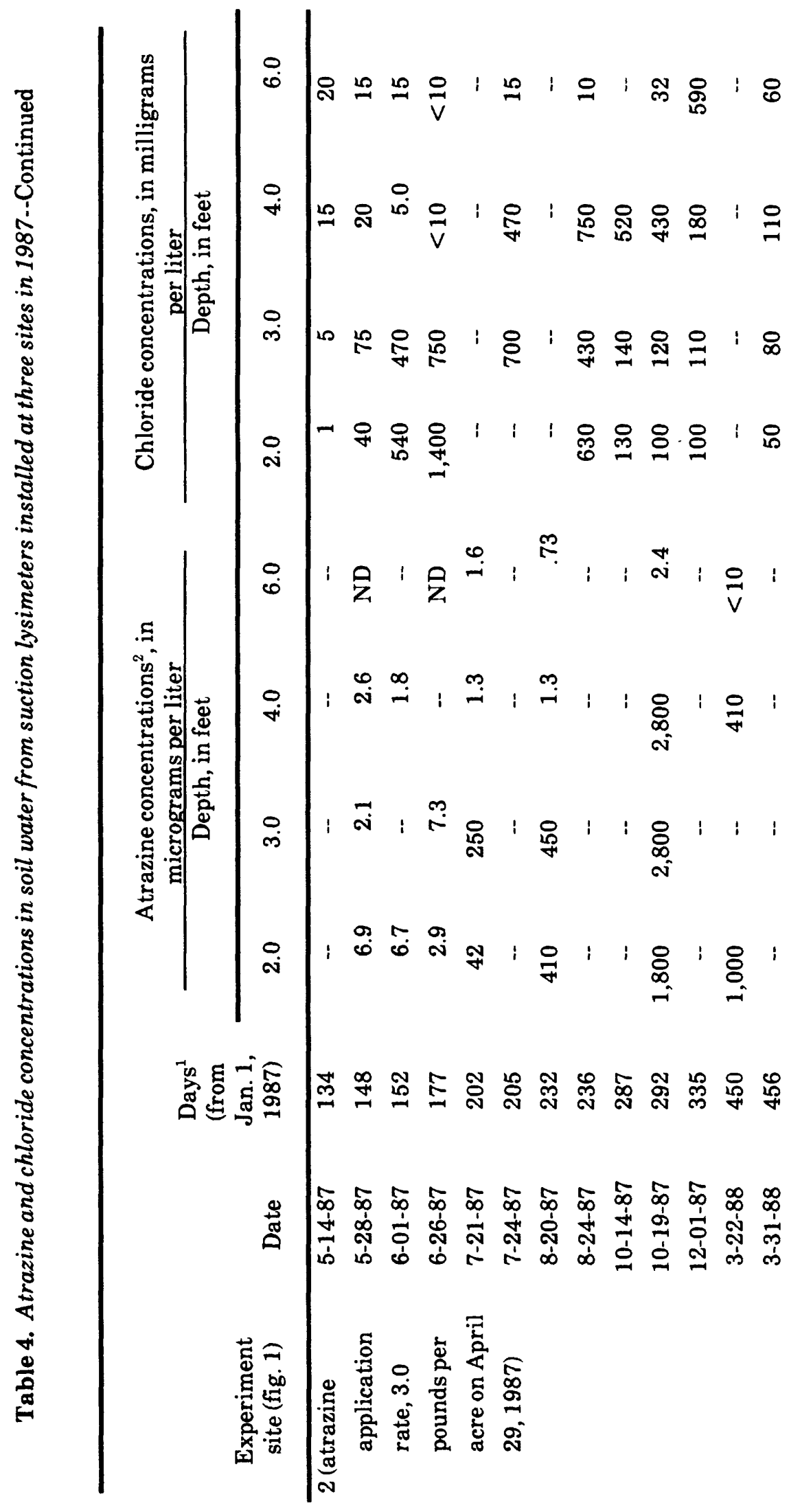




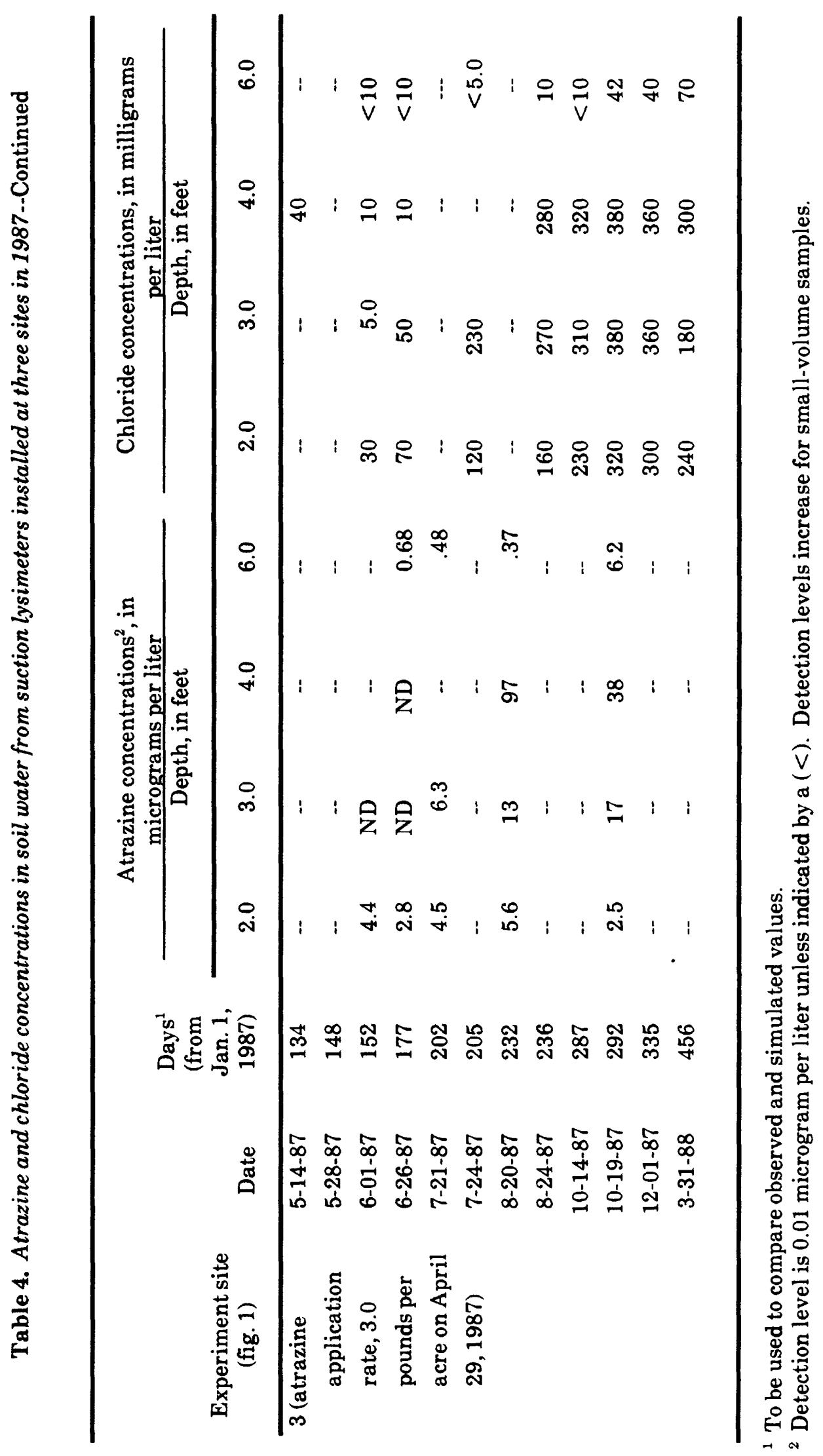




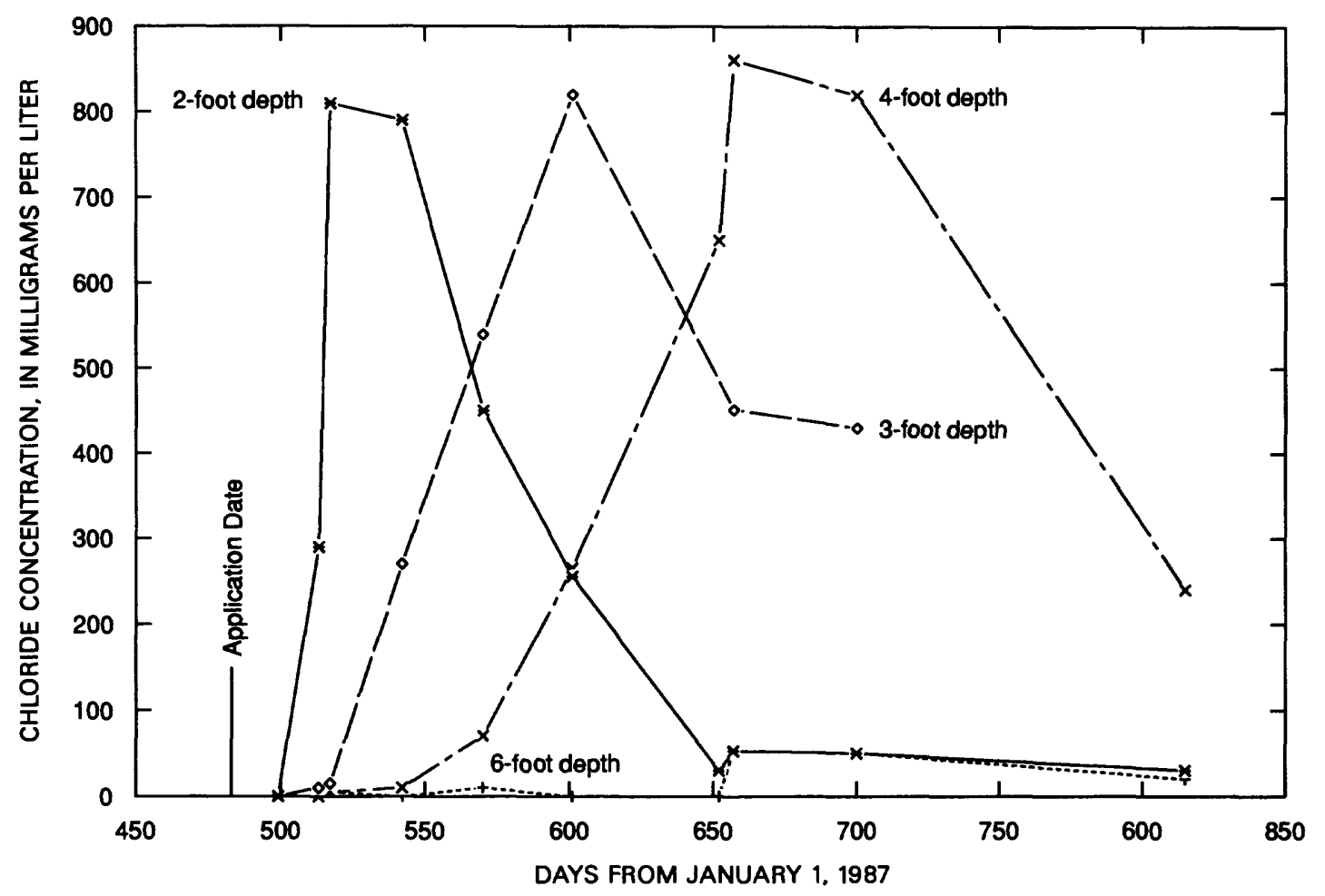

Figure 6. Chloride concentrations in soil water from suction lysimeters in silty loam, 1987.

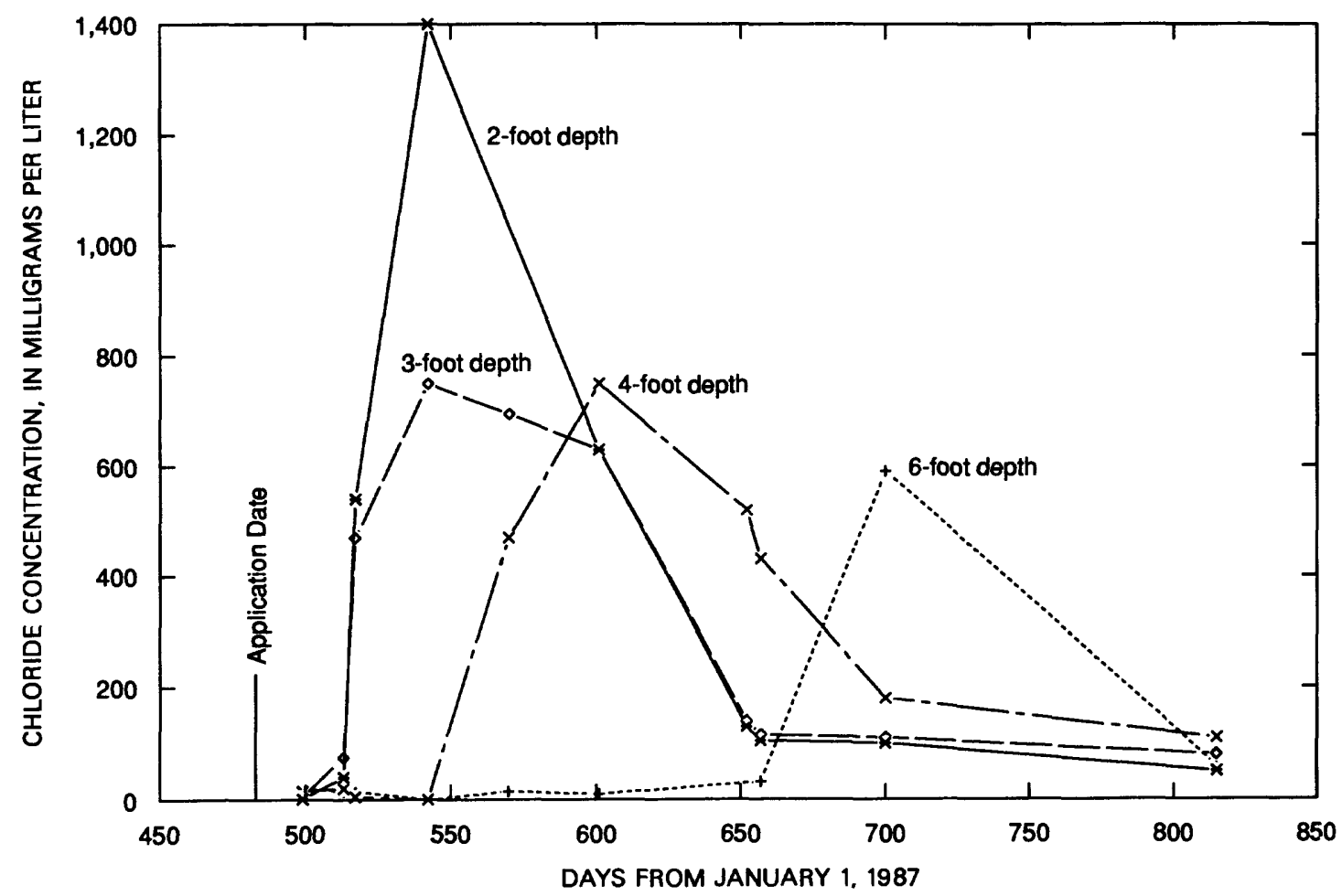

Figure 7. Chloride concentrations in soil water from suction lysimeters in sandy loam, 1987. 


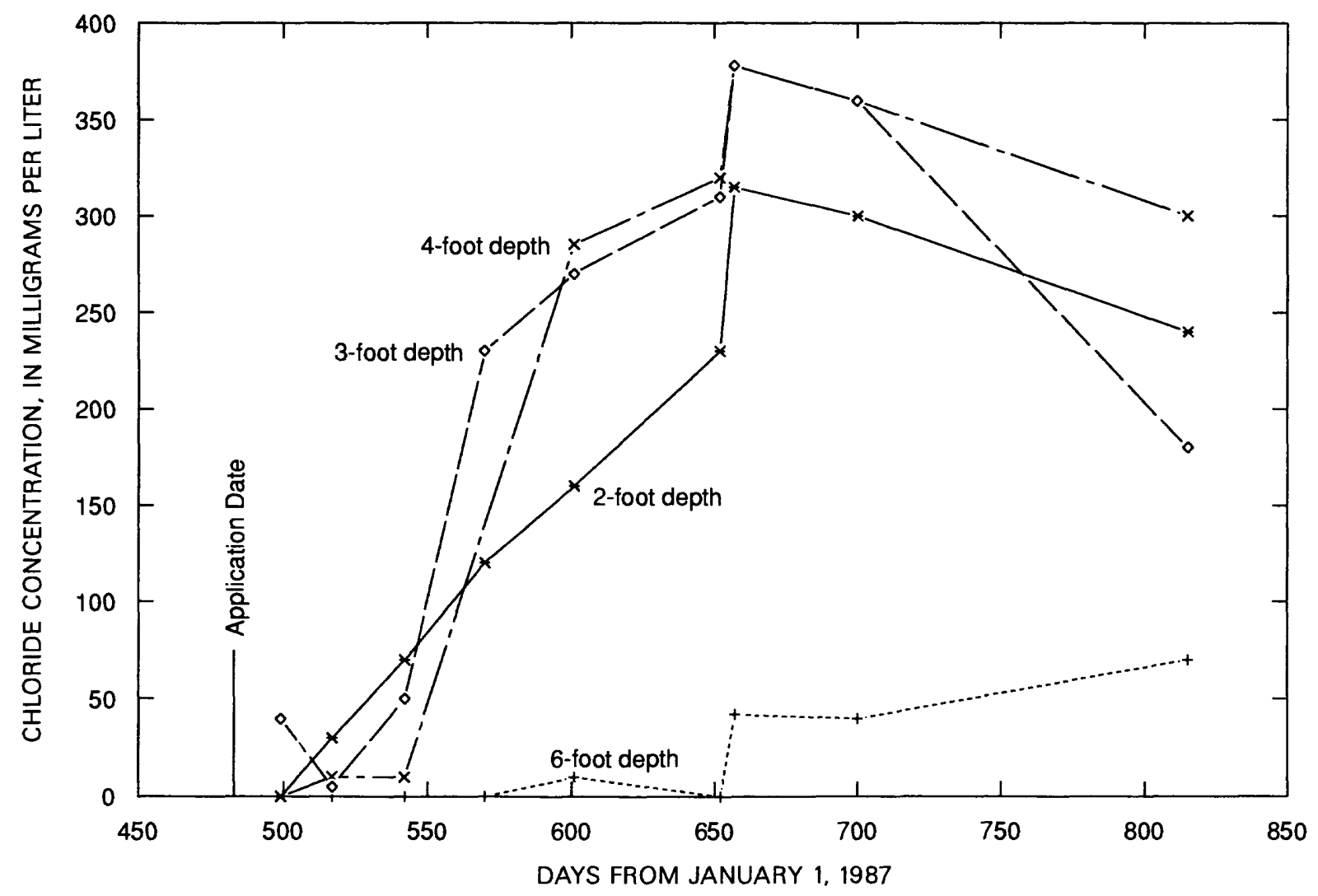

Figure 8. Chloride concentrations in soil water from suction lysimeters in clay, 1987.

Farm and their half-lives in soil. Also included in table 8 is the estimated half-lives for the same herbicides in a saturated environment (Perry, 1990). Half-lives in the unsaturated zone are expected to increase with depth as biologic activity decreases, temperature decreases, and oxygen becomes less a vailable.

\section{SIMULATED DISTRIBUTION OF HERBICIDES}

\section{Pesticide Root Zone Model}

The Pesticide Root Zone Model (PRZM) is a dynamic, compartmental model for use in simulating chemical movement in the unsaturated soil system within and below the plant-root zone (Carsel and others, 1984). The model is depicted by a schematic diagram in figure 9. The model is a one-dimensional approximation of processes occurring at the surface, in the root zone, and in the area between the root zone and the water table. The PRZM is structured around two major components-- hydrologic and chemical transport. The hydrologic component is divided among runoff and erosion, evapotranspiration, and flow through porous media. The runoff and erosion subdivision is based on the U.S. Soil and Conservation Service curve-number technique the universal soil-loss equation. Evapotranspiration can be either input to the model directly, estimated from pan evaporation, or generated from an empirical formula if pan data are not available. Evapotranspiration is divided among evaporation from crop interception, evaporation from soil, and transpiration from the crop. Flow through porous media is simulated by the use of generalized soil characteristics, including field capacity, wilting point, and saturation. The model does not have any capacity to simulate macropore flow. The chemical-transport component calculates pesticide losses, including uptake by plants, surface runoff, erosion, decay, vertical movement, foliar washoff, dispersion, and retardation to produce soil-water and solidphase concentrations. A finite-difference 
Table 5. Atrazine concentrations in soil cores from ring lysimeters installed at three sites in 1987

$$
[<\text {, less than }]
$$

\begin{tabular}{|c|c|c|c|c|c|c|c|}
\hline \multirow{3}{*}{$\begin{array}{c}\text { Experiment site } \\
\text { (fig. 1) }\end{array}$} & \multirow[b]{3}{*}{ Date } & \multirow{3}{*}{$\begin{array}{l}\text { Days }^{1} \text { (from } \\
\text { Jan. 1, 1987) }\end{array}$} & \multicolumn{5}{|c|}{ Concentrations, in micrograms per kilogram } \\
\hline & & & \multicolumn{5}{|c|}{ Depth interval, in feet } \\
\hline & & & $0-1.0$ & $1.0-2.0$ & $2.0-3.0$ & $3.0-4.0$ & $4.0-6.0$ \\
\hline 1 (atrazine & $5-28-87$ & 148 & 6,900 & $<4.0$ & $<4.0$ & 13 & 86 \\
\hline application & $6-26-87$ & 177 & 6,000 & 19 & 28 & 22 & 77 \\
\hline rate, 1.5 & 8-10-87 & 222 & 2,300 & 54 & 150 & 230 & 110 \\
\hline pounds per & $10-19-87$ & 292 & 1,600 & 9.6 & $<4.0$ & $<4.0$ & $<4.0$ \\
\hline acre) & $3-22-88$ & 450 & 1,500 & 6.1 & 5.8 & $<4.0$ & 50 \\
\hline (atrazine & $5-28-87$ & 148 & 5,800 & 16 & 260 & 170 & 7.7 \\
\hline application & $6-26-87$ & 177 & 32,000 & 143 & 65 & 48 & 100 \\
\hline rate, 3.0 & $8-10-87$ & 222 & 11,000 & 46 & 70 & 280 & 1,300 \\
\hline pounds per & $10-19-87$ & 292 & 4,000 & 36 & $<4.0$ & $<4.0$ & $<4.0$ \\
\hline acre) & $3-22-88$ & 450 & 3,600 & 39 & 40 & 50 & 32 \\
\hline 2 (atrazine & $5-28-87$ & 148 & 5,600 & 4.0 & 4.3 & $<4.0$ & $<4.0$ \\
\hline application & $6-26-87$ & 177 & 8,600 & 740 & 34 & 72 & $<4.0$ \\
\hline rate, 1.5 & $8-10-87$ & 222 & 1,900 & 1,300 & 100 & 320 & $<4.0$ \\
\hline pounds per & $10-19-87$ & 292 & 72 & 46 & 210 & 210 & $<4.0$ \\
\hline acre) & $3-22-88$ & 450 & 160 & 53 & 130 & 250 & 35 \\
\hline (atrazine & $5-28-87$ & 148 & 26,000 & 45 & $<4.0$ & 10 & 4.0 \\
\hline application & $6-26-87$ & 177 & 22,000 & 310 & 160 & 85 & 94 \\
\hline rate, 3.0 & $8-10-87$ & 222 & 4,200 & 2,300 & 730 & 790 & 58 \\
\hline pounds per & $10-19-87$ & 292 & 6,300 & 480 & 950 & 34 & 25 \\
\hline acre) & $3-22-88$ & 450 & 4,800 & 360 & 540 & 720 & 35 \\
\hline 3 (atrazine & $6-01-87$ & 152 & 7,200 & 24 & 64 & 72 & 17 \\
\hline application & $6-26-87$ & 177 & 1,900 & 13 & 6.2 & 49 & 5.2 \\
\hline rate, 1.5 & $8-10-87$ & 222 & 2,900 & 110 & 2,100 & 470 & 87 \\
\hline pounds per & $10-19-87$ & 292 & 1,000 & 11 & 73 & 52 & 9.0 \\
\hline acre) & $3-22-88$ & 450 & 150 & 7.2 & 14 & 21 & $<4.0$ \\
\hline (atrazine & $5-28-87$ & 148 & 6,400 & 220 & 820 & 1,100 & 840 \\
\hline application & $6-26-87$ & 177 & 3,200 & 120 & 130 & 280 & 480 \\
\hline rate, 3.0 & $8-10-87$ & 222 & 11,000 & 120 & 340 & 350 & 1,100 \\
\hline pounds per & $10-19-87$ & 292 & 4,500 & 20 & 11 & 45 & $<4.0$ \\
\hline acre) & $3-22-88$ & 450 & 1,900 & 18 & 37 & 81 & 7.7 \\
\hline
\end{tabular}

${ }^{1}$ To be used to compare observed and simulated values. 


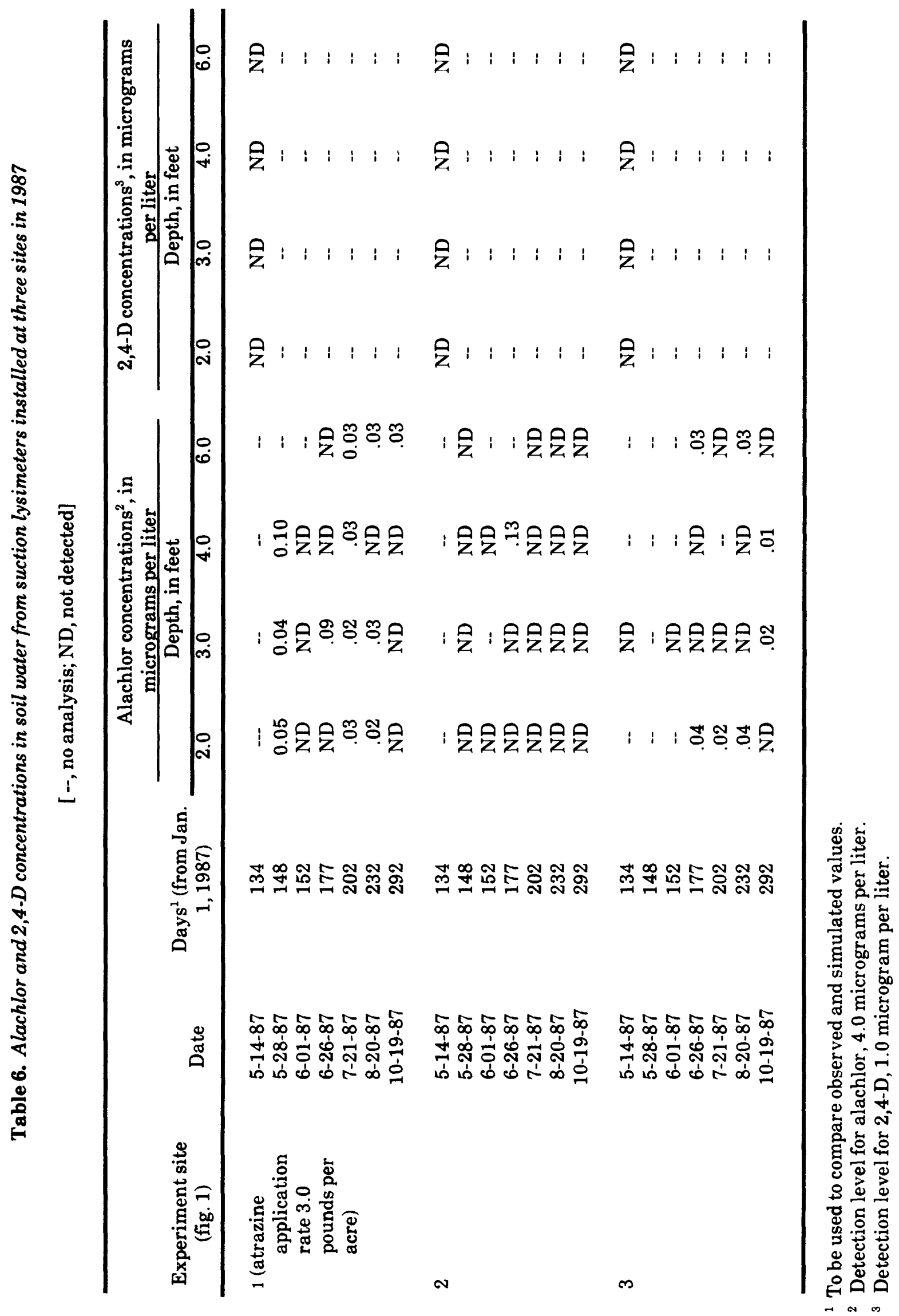




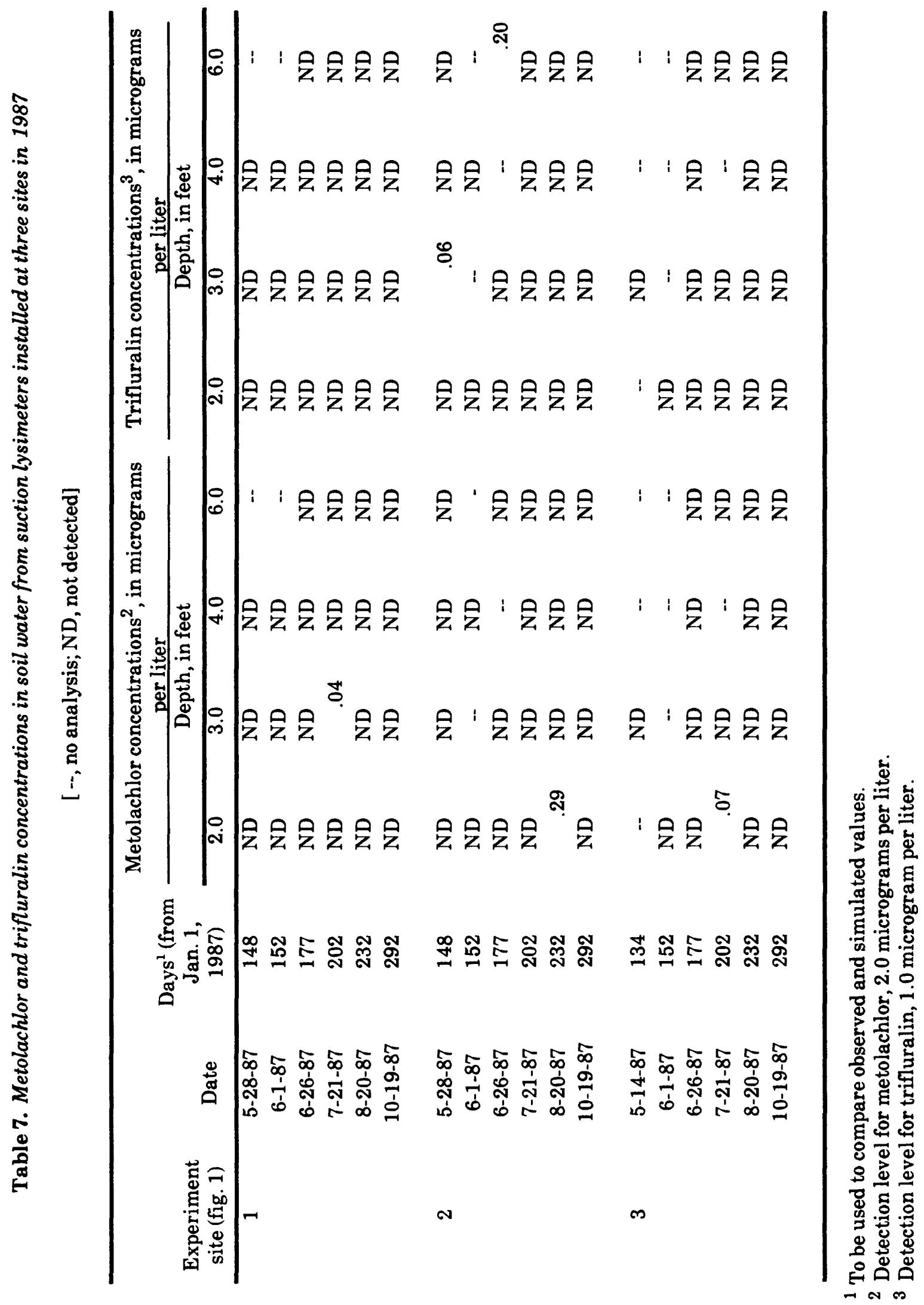


Table 8. Half-lives for alachlor, atrazine, cyanazine, metolachlor, metribuzin, trifluralin, and 2,4-D in soil and saturated material

$$
[--, \text { no data }]
$$

\begin{tabular}{lcrc}
\hline & $\begin{array}{c}\text { Solubility } \\
\text { (milligrams } \\
\text { per liter) }\end{array}$ & Soil half-life & \\
$\begin{array}{l}\text { Herbicide } \\
\text { (days) }\end{array}$ & (days) & Saturated half-1ife ${ }^{2}$ \\
\hline Alachlor & 220 & $26-70$ & 400 \\
Atrazine & 70 & $67-365$ & 1,000 \\
Cyanazine & 171 & $14-20$ & 250 \\
Metolachlor & 530 & $15-50$ & 350 \\
Metribuzin & 1,200 & $7-28$ & 350 \\
Trifluralin & 24 & $10-384$ & -- \\
$2,4-D$ & insoluble & $7-28$ & -- \\
\hline
\end{tabular}

1 From Perry and others, 1988.

2 From Perry, 1990.

numerical solution, using a backwardsdifference implicit scheme, is used.

The reader is referred to Carsel and others (1984) for the theoretical basis of the equations and algorithms used within the model structure. The estimation or calculation of the more than 60 input parameters, the operational modeling considerations, and simulation strategy also are outlined by Carsel and others (1984).

A major objective of this study was to compare the observed movement of herbicides with movement simulated by PRZM and LEACH. As stated in the section on "Leaching Experiment Design," two major factors within the dynamics of herbicide movement were assumed to be negligible. These factors were surface runoff and plant uptake. In this way, the most important component of the PRZM, leaching, could be evaluated objectively.

The comparison was accomplished using 1987-88 data in two steps of matching simulated chloride and herbicide concentrations with observed concentrations. In the first step, observed data were used for the input parameters. In the second step, a systematic adjustment to the input data for all three soil types was made to attempt a calibration of simulated concentrations to the observed concentrations. The model simulations were begun on January 1, 1987.

\section{Use of Observed Input Data}

Simulated concentrations for the conservative tracer, potassium chloride, were compared to observed concentrations for the silty loam, sandy loam, and clay soil. There was no correlation $(R=0)$ between the observed and simulated chloride concentrations (see "Supplemental Information" at the end of this report). The inability of the model to match the observed chloride concentrations may be due in part to the lack of consideration of macropore flow. However, macropore flow should decrease with depth, so that the observed and simulated difference should become less with depth. An example of the comparison of observed concentrations with simulated chloride concentrations in soil water at the 3- and 6-foot depths for the silty loam site is shown in figure 10. Table 9 lists the simulated chloride concentrations in soil water. 


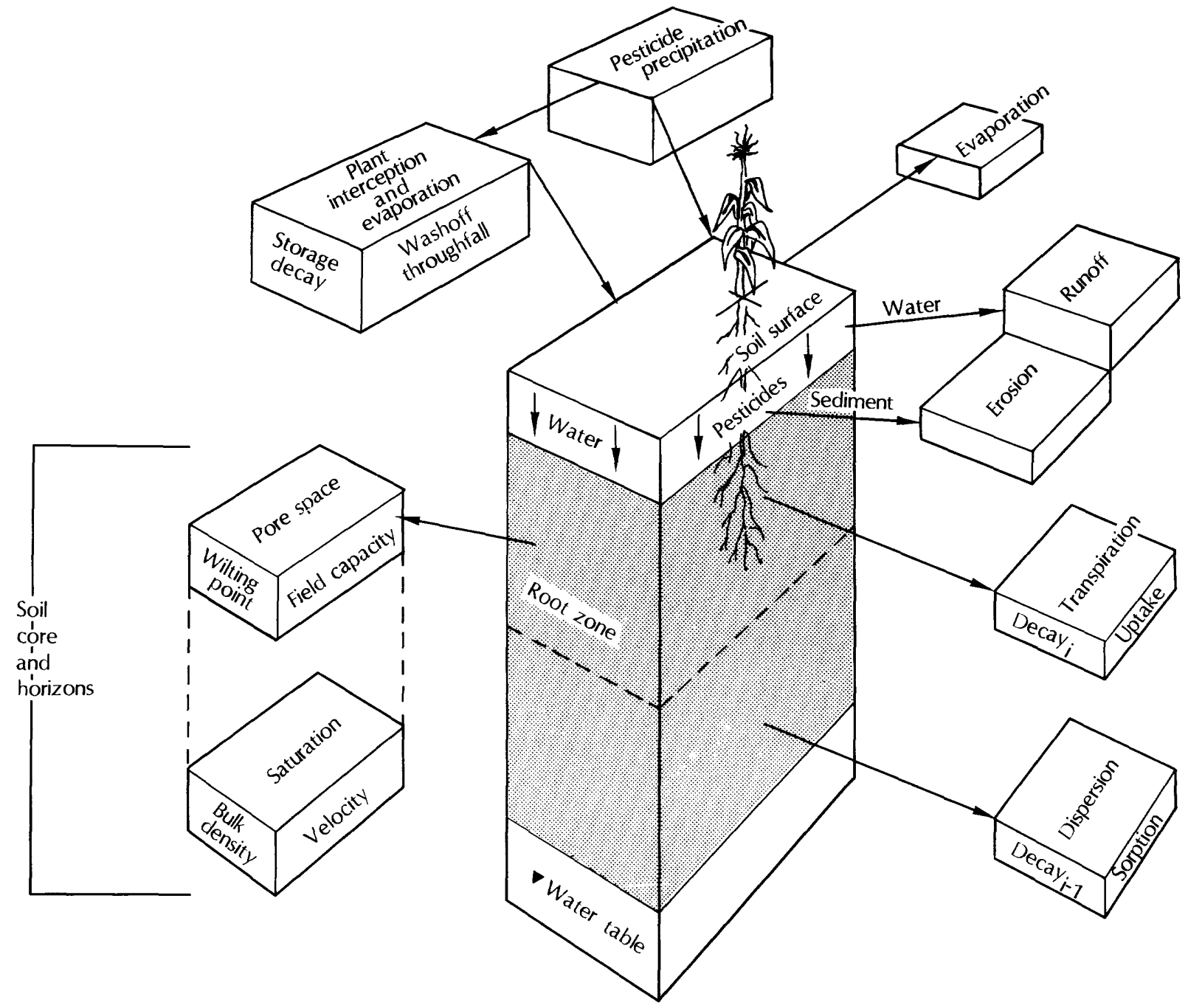

Figure 9. Pesticide Root Zone Model (modified from Carsel and others, 1984).

\section{Use of Adjusted Input Data}

Input variables were adjusted to improve the comparison between observed and simulated concentrations. The elimination of the runoff and plant-uptake components left only the soil parameters and the properties of the leaching chemical to be modified. Soil parameters in this investigation included mineral bulk density, soil moisture, hydrodynamic dispersion, sand fraction, clay fraction, and the organic-carbon content. Chemical properties included solubility and half-life.

In trial simulations, the model results were found to be most sensitive to changes in soil moisture, sand and clay fraction, organic-carbon content, and chemical solubility and herbicide half-life. For calibration purposes chemical solubility was not adjusted. Solubility is a precise laboratory measurement. For chloride leaching, the half-life is infinite, and solubility is very large, which results in little effect of organic-carbon content. Soil moisture is a function of precipitation, depth of evapotransportation in the soil, and particle-size distribution of the soil. In all model simulations, soil moisture was initialized at a value of field capacity, then allowed to equilibrate with the observed precipitation and evapotranspiration. This process of elimination left the sand and clay fraction as the only variable to be adjusted to simulate the transport of chloride. Laboratory analysis of particle-size distribution does not 


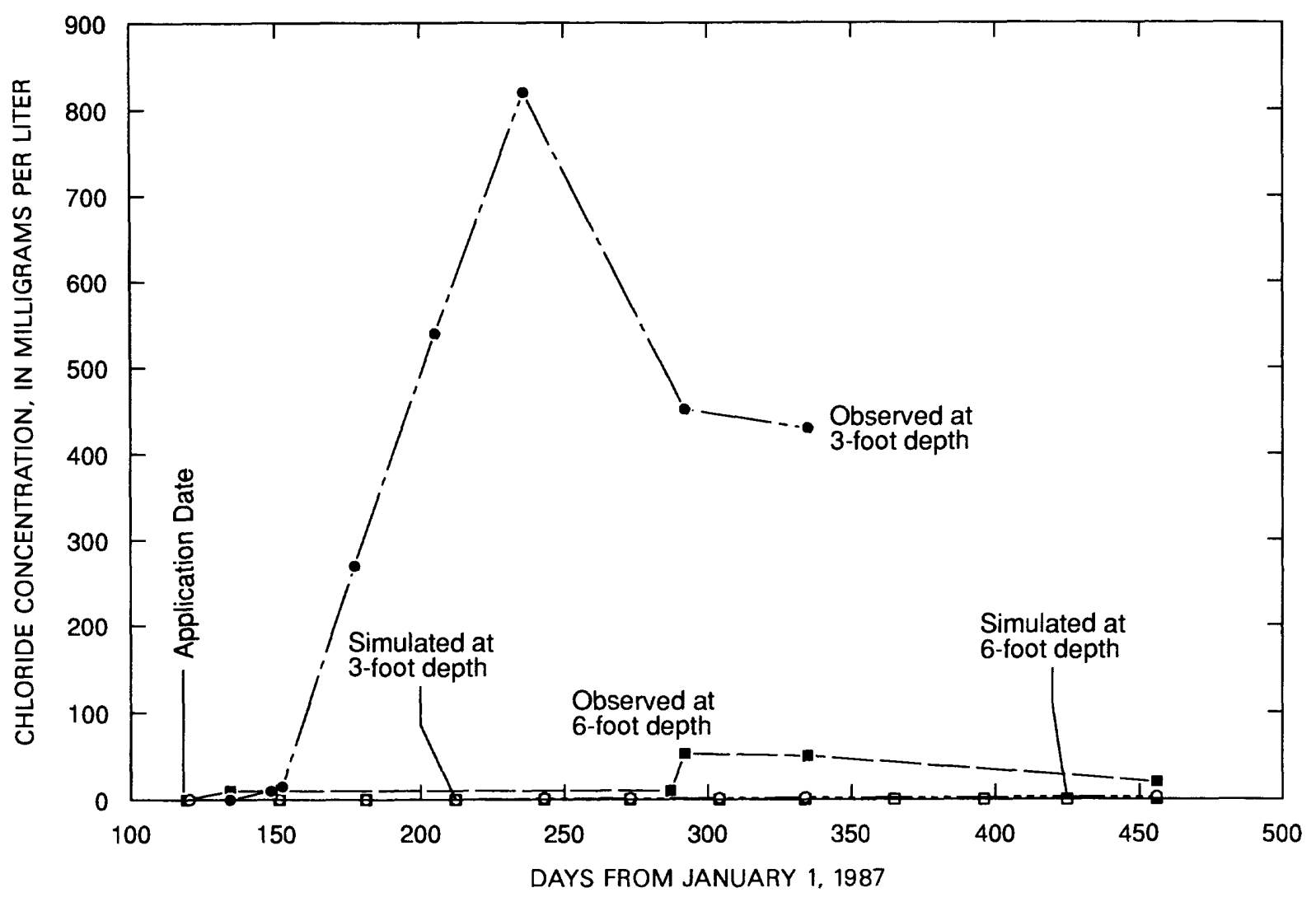

Figure 10. Observed and simulated chloride concentrations in soil water at 3-and 6-foot depths at silty loam site (site 1, fig. 1).

consider the macropores caused by worm holes and roots; therefore, the adjustment of sand and clay fraction was justified.

Various trial simulations using different particle-size distributions were made. In an application of the PRZM model, the sand fraction and the clay fraction are user-input variables, and the model computes the silt fraction. Chloride movement was best modeled when the silt fraction was included in the sand fraction. In this manner, the model detects no silt and computes a more permeable soil. A plot of particle-size distribution and organic-carbon content used in PRZM simulations is depicted in figure 11 for the silty loam site. In comparing all observed and all simulated chloride concentrations, the correlation coefficient was increased to $R=0.51$ from the previous $R=0$. Table 10 lists simulated chloride concentrations in soil water for 1987-88.

Once the simulation of the conservative tracer was optimized, the herbicide atrazine was modeled with the adjusted sand and clay fractions. Simulated concentrations for applications of the herbicide atrazine with a halflife of $\mathbf{1 5 0}$ days were compared to the observed values for the silty loam, sandy loam, and clay soil. The correlation between the observed atrazine concentrations and the simulated concentrations was poor $(R=0.42)$. An example of the comparison of observed atrazine concentrations with simulated concentrations at the 3- and 6-foot depths for the silty loam site is shown in figure 12. The simulated atrazine concentrations lagged behind the simulated chloride concentrations (fig. 10) to the extent that degradation decreased herbicide concentrations to less than laboratory detection levels (2.0 micrograms per kilogram in soil; 0.10 microgram per liter in water). Table 11 lists the simulated atrazine concentrations in soil and soil water.

Simulated atrazine concentrations continued to be several orders of magnitude less than the observed values. The half-life of most herbicides in the soil varies considerably with depth and degree of saturation (Perry and others, 1988). The PRZM model was tested using an average half-life for atrazine of 150 days in 


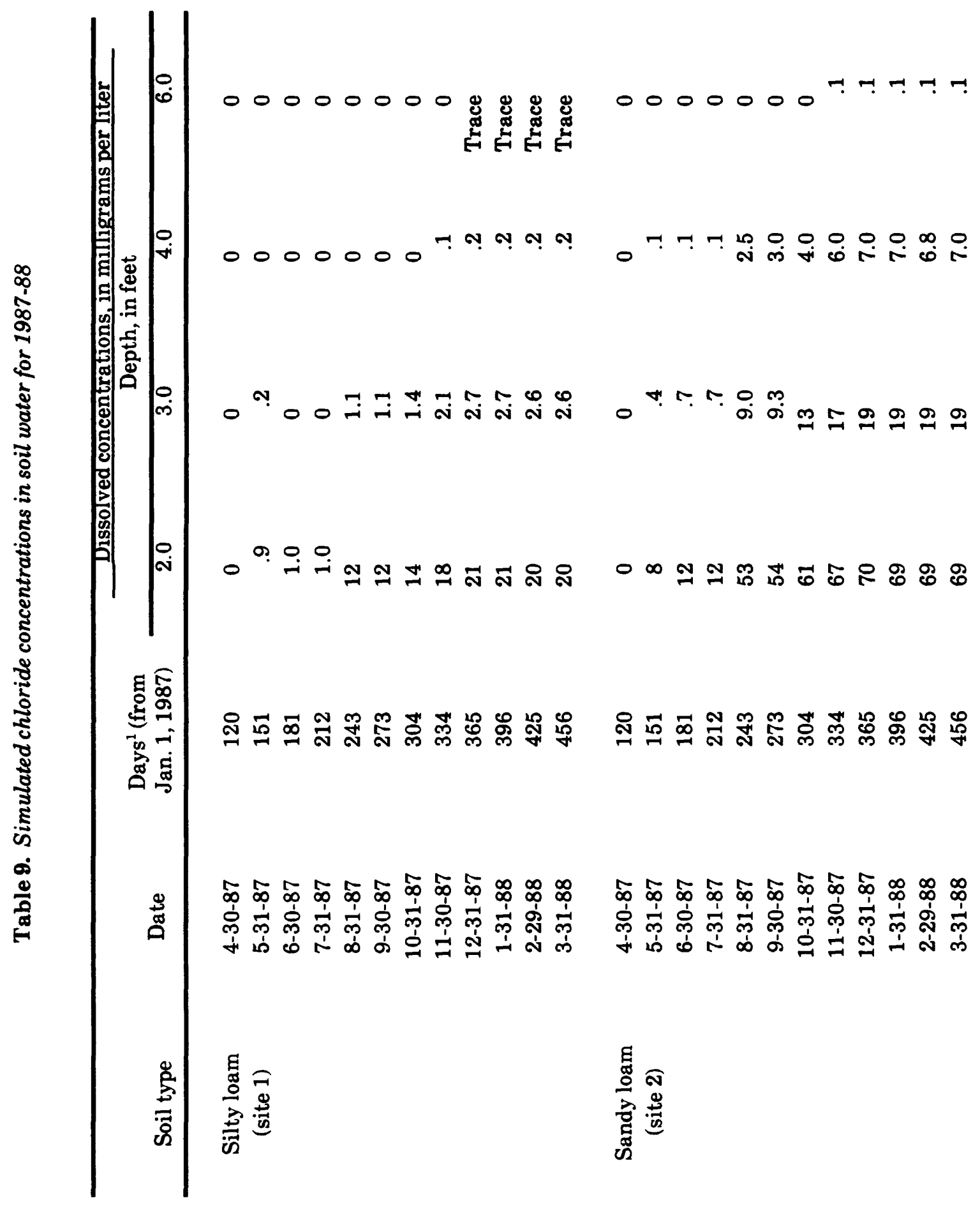




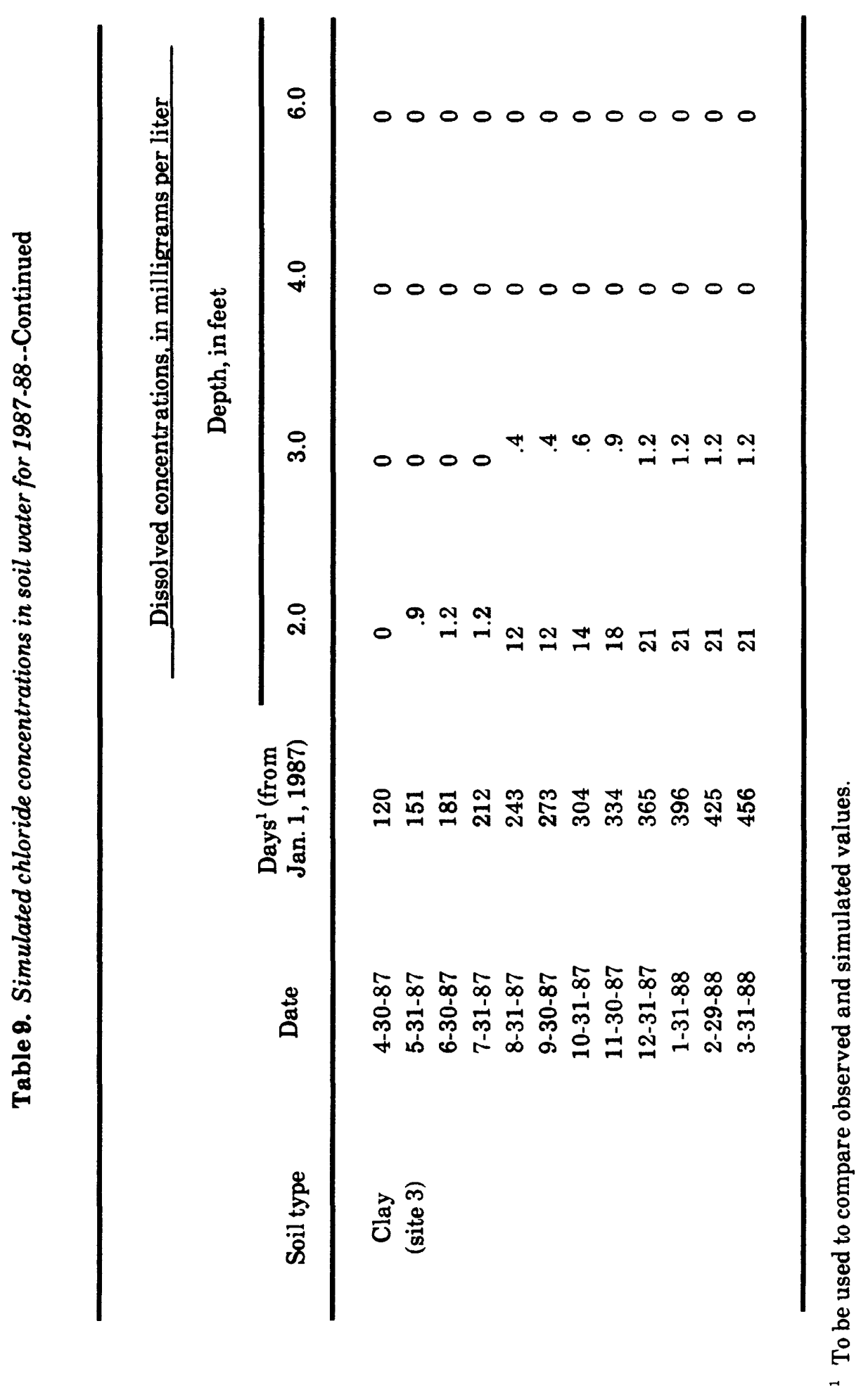




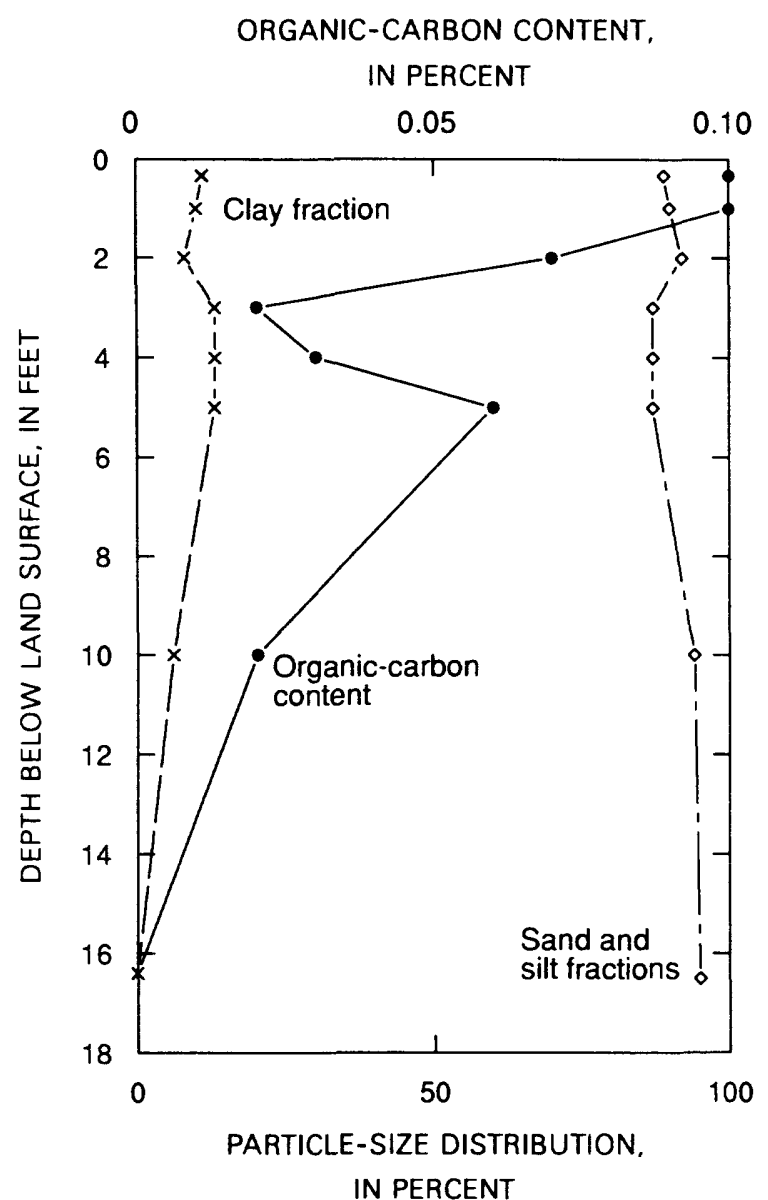

Figure 11. Soil particle-size distribution and organic-carbon content for PRZM simulations of silty loam.

the surface layer ( 0 to 1 foot), increasing to 1,000 days at the 6-foot depth. This adjustment improved the match between observed and simulated atrazine concentrations in the top 1 to 2 feet. However, the correlation between observed and simulated concentrations remained poor below 2 feet as observed concentrations were much larger than those simulated. This poor association was probably the result of atrazine sorption onto organic carbon in the soil in the simulation.

Sorption-desorption characteristics of organic chemicals in the soil and soil water are affected by interrelations among soil moisture, soil particle-size distribution, and soil organic carbon (Carsel and others, 1984). Soil moisture is a function of precipitation, particle size, and evapotranspiration. The particle size had already been adjusted in the model by classifying silt as sand. The only factor remaining was organic-carbon content. This adjustment could be considered allowance for macropore flow. Therefore, trial model simulations were made varying the percentage of organic-carbon content of each layer by an equal amount. The best match with the observed data was achieved using an adjustment of 0.1 times the measured organic-carbon content. This adjustment could be considered an allowance for macropore flow. Table 12 lists calibrated atrazine concentrations in soil and soil water. With the adjustment of both atrazine half-life and organic content of the soil, the correlation between observed dissolved atrazine concentrations and the values generated by the calibrated model increased to $R$ $=0.62$ for all sites and all depths. A plot of output from the calibrated model with observed data is shown in figure $\mathbf{1 3}$ for the sandy loam site and a 6-foot depth. Correlation between observed and simulated atrazine concentrations in soil cores with all model adjustments remained poor $(R=0.22)$.

\section{Calibration Summary}

The PRZM was best calibrated to the observed data for the three soil types by treating the sand-and-silt fraction as sand and adjusting the organic-carbon content by a factor of 0.1 . These adjustments provided the best overall correlation between observed and modeled values. These adjustments are simple and can be justified as corrections by the fact that the PRZM does not allow for macropore flow. Increasing the half-life of the herbicide with depth and degree of saturation has been shown to occur in saturated conditions and appears to be applicable to the unsaturated regime below the root zone. These three major adjustments to the input data for the PRZM improved the correlation between observed and simulated concentrations of atrazine for the three soil types and at all depths from $R=0$ to $R=0.62$. The "Supplemental Information" section at the end of this report includes a table of the root-mean-square computations for chloride and atrazine concentrations in soil water for each soil type and depth.

\section{Calibrated-Model Simulations}

With the PRZM calibrated to observed data, simulations of herbicide movement and 


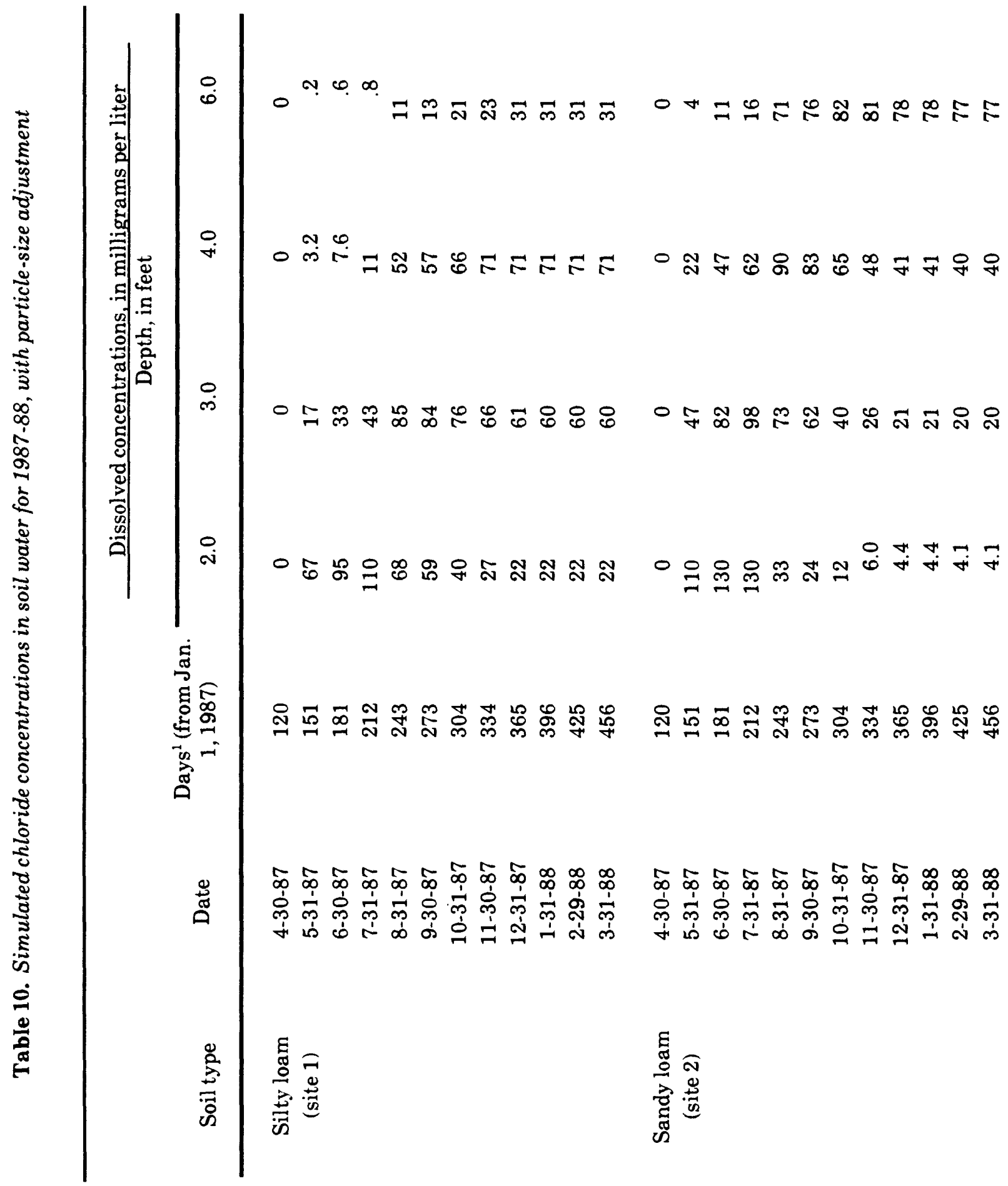




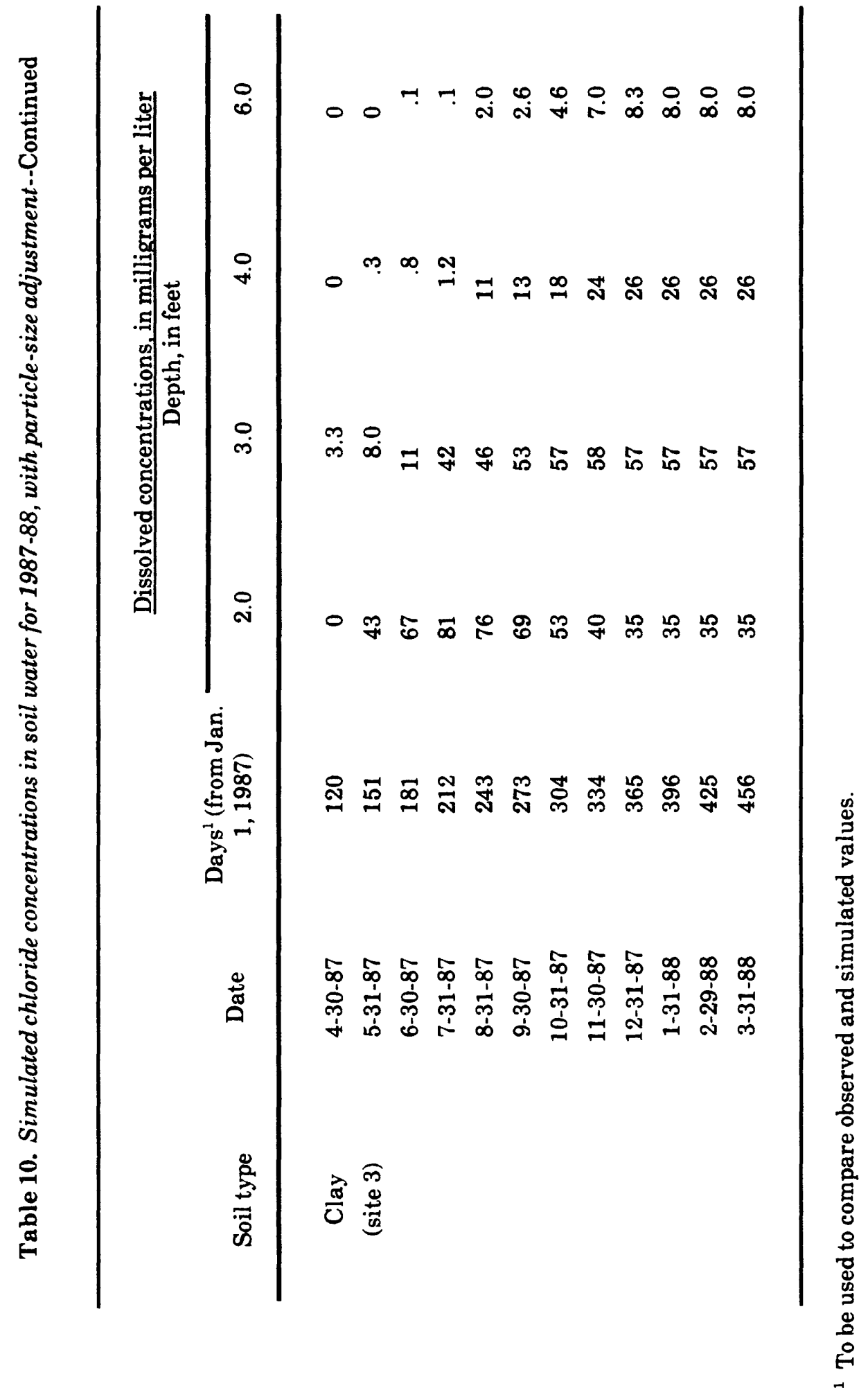




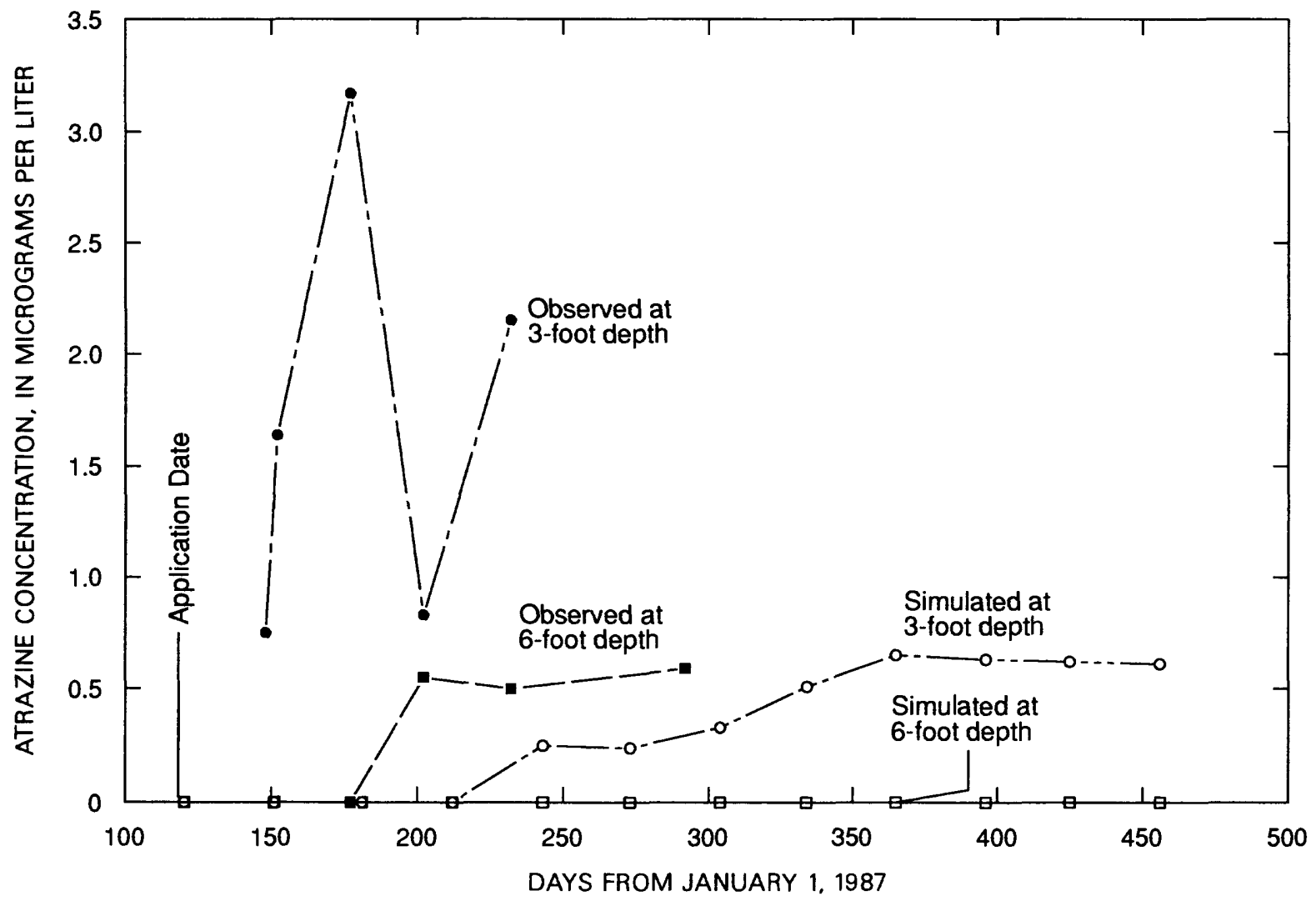

Figure 12. Observed and simulated (with particle-size adjustment) atrazine concentrations in soil water at 3-and 6-foot depths at silty loam site (site 1, fig. 1).

distribution were made under various hypothetical conditions. Simulations were made using the three soil types under one-half normal, normal, and twice-normal annual precipitation. Simulations were made with normal and twicenormal herbicide-application rates. Chemigation was simulated by applying onethird of the herbicide at planting and the remaining two-thirds on two other occasions when irrigation water was applied. Two irrigation applications of 12 and 32 inches of water were simulated. Finally, four different herbicides with varying solubility and half-lives were simulated for comparison.

The model was calibrated using the best fit for data at the 2-, 3-, 4-, and 6-foot depths for all three soil types. Data presented in this section of the report for various model simulations are limited to depths of 6 feet, just below the maximum root zone, and at 16 feet, which was the water table. The soil particle-size distribution and organic-carbon content used in the simulations are shown in figures 11,14 , and
15. Meteorological data for 1987 were used in the simulations. The simulations were run for 2 years with rainfall and atrazine-application amounts and dates as shown in figure 16. The model date begins at 0 for January 1 and runs to 730 for December 31 of the following year. The 12-inch chemigation simulations were run with amounts and dates shown in figure 17. The 32inch chemigations had the same atrazineapplication amounts and dates.

\section{ConventionaI Atrazine Application}

Simulations for the three soil types were first run using an annual precipitation total of 37.64 inches (1987 value), which was 109 percent of the normal amount for 1951-80. In figure 18A, soil-water concentrations at the 6-foot depth show little atrazine leaching in the silty loam and clay soil, but the sandy loam shows significant leaching the first year and increasing the following year. At the 16-foot depth (fig. 18B), the sandy loam shows a rapid increase the second year. 


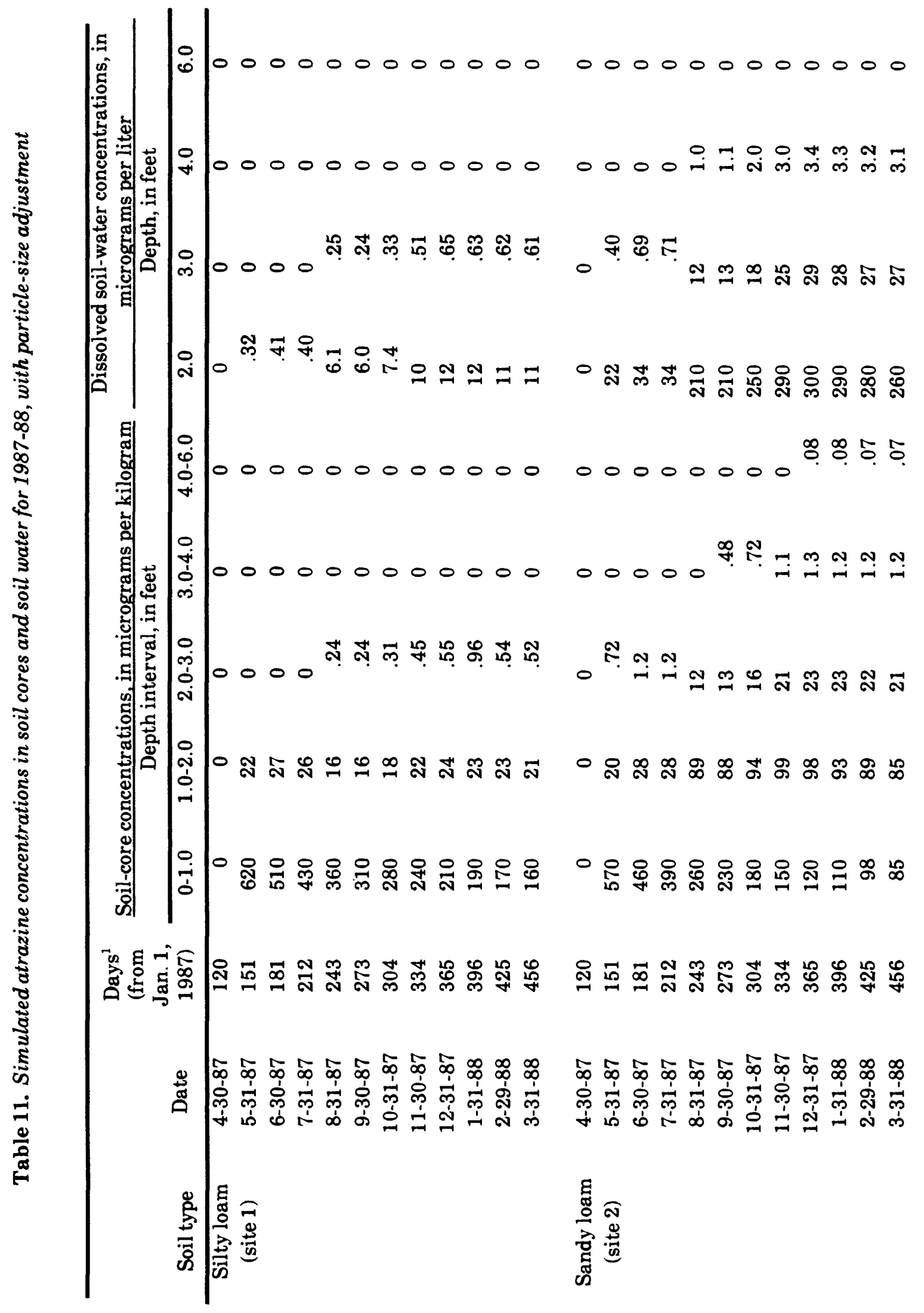




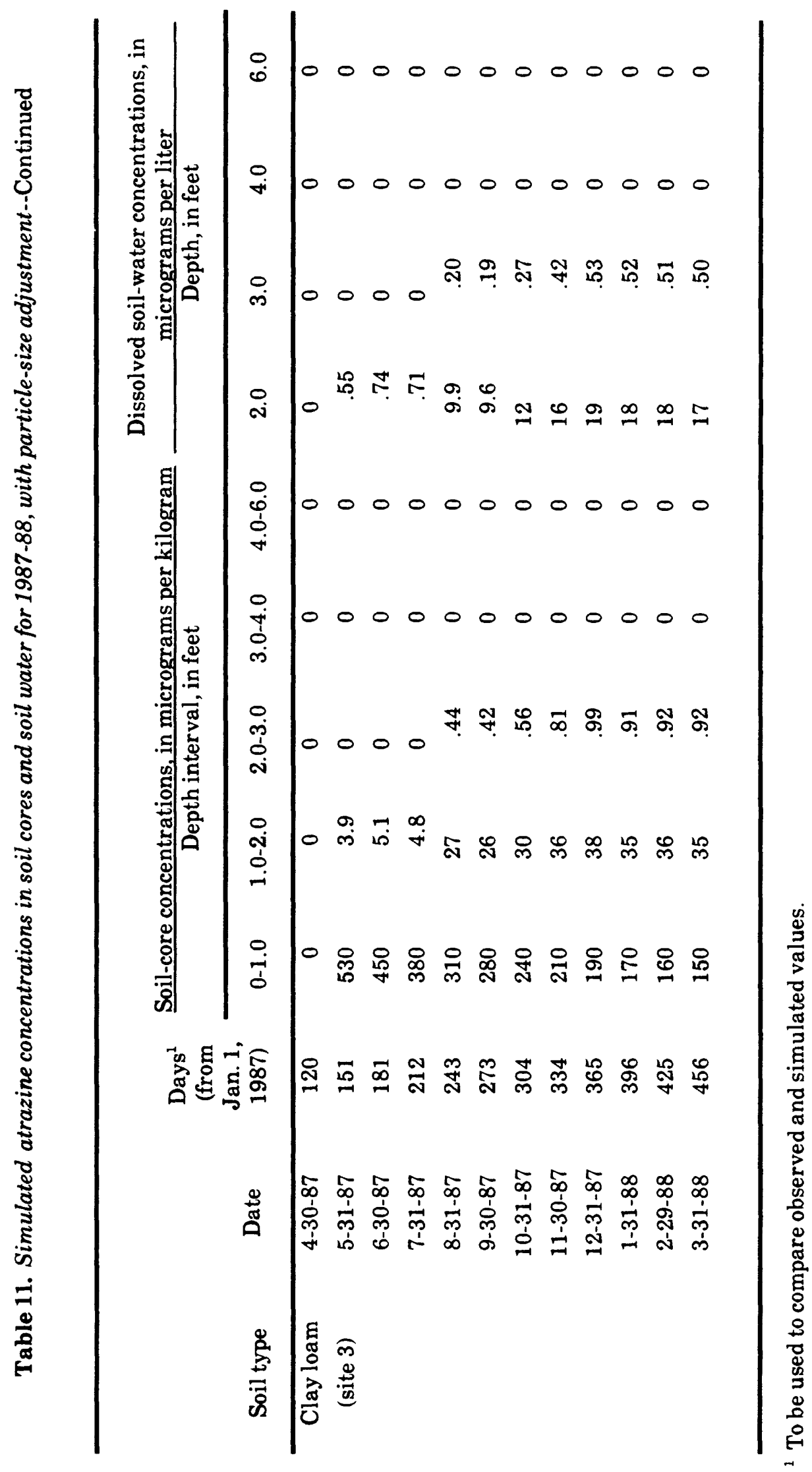




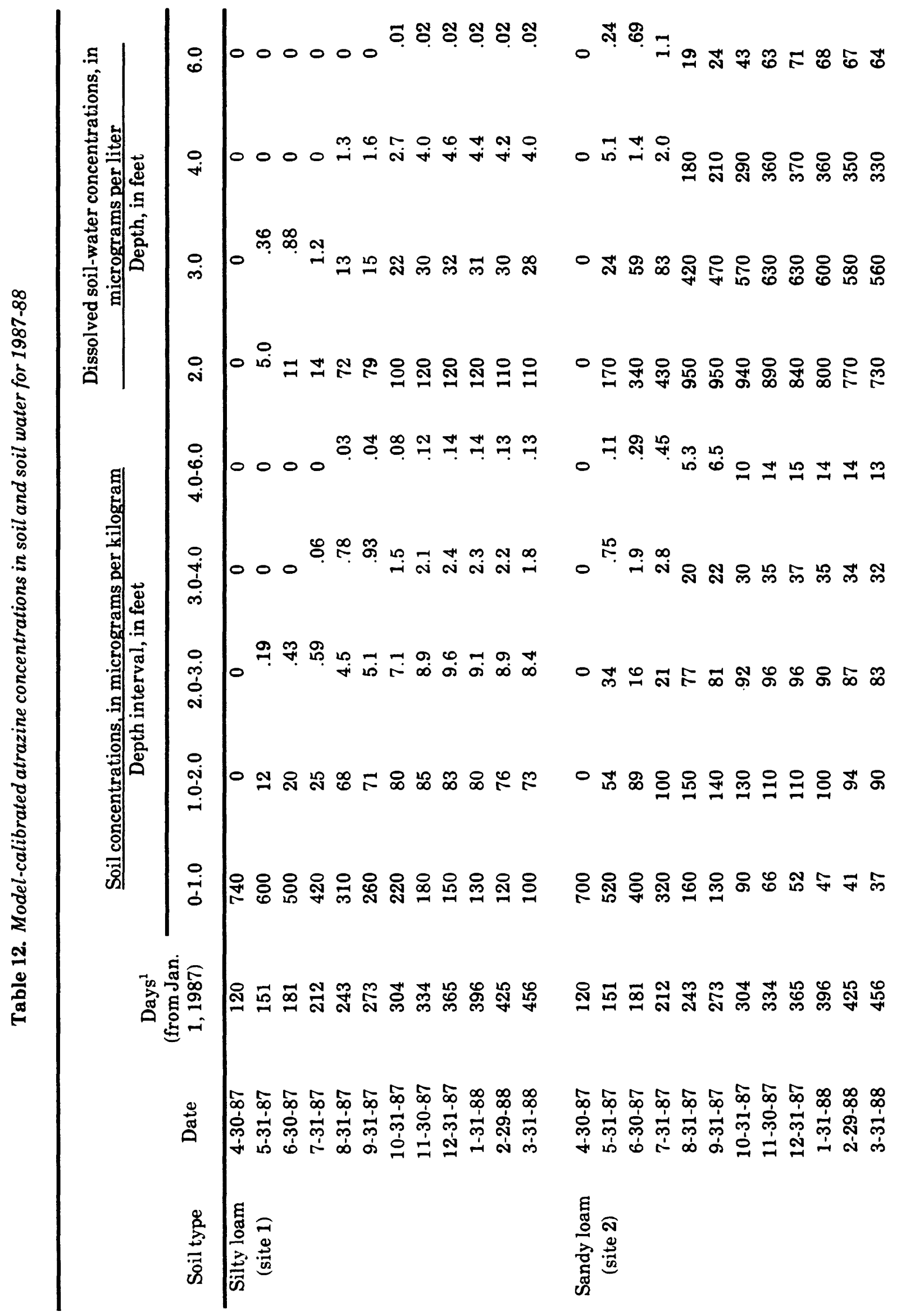




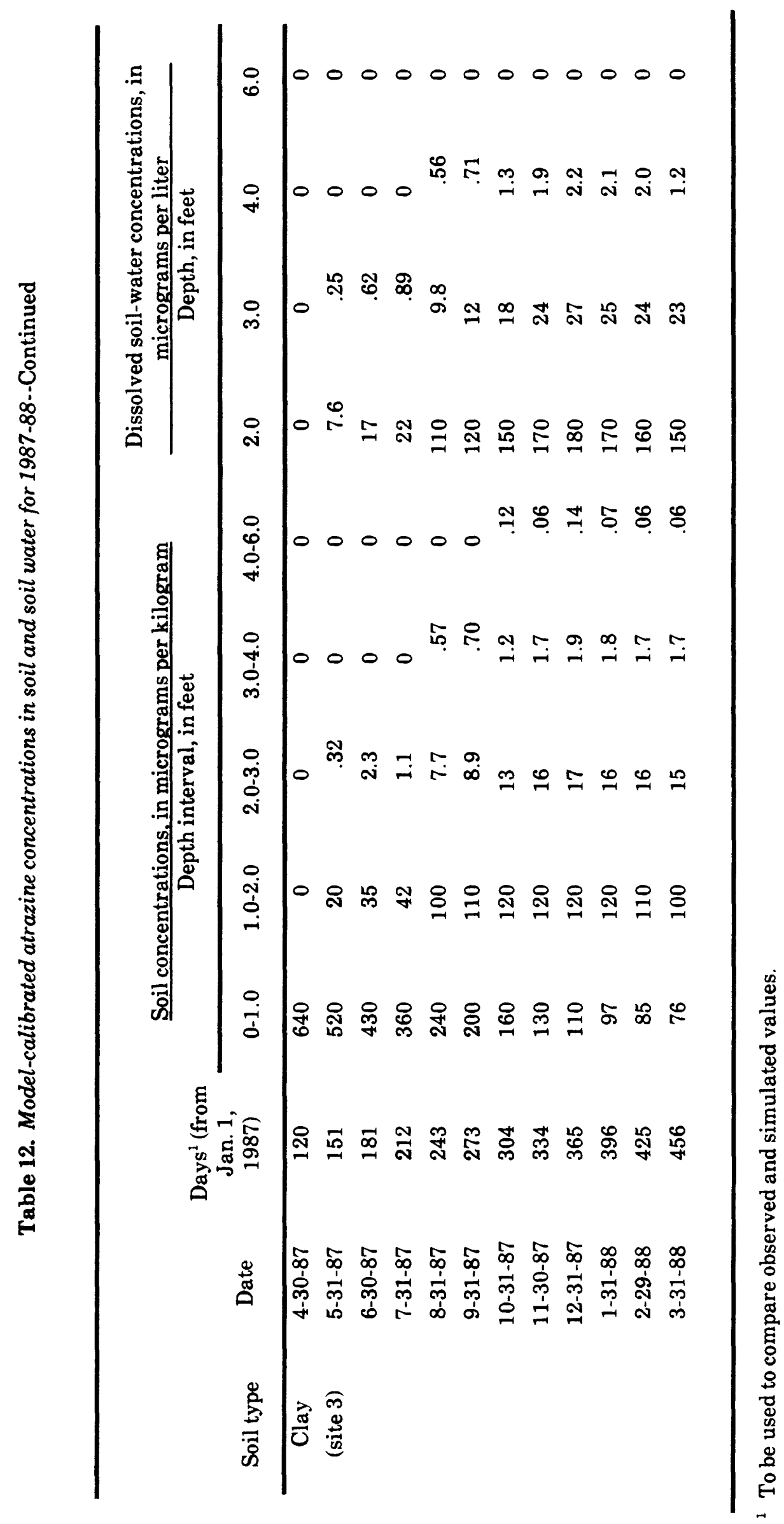




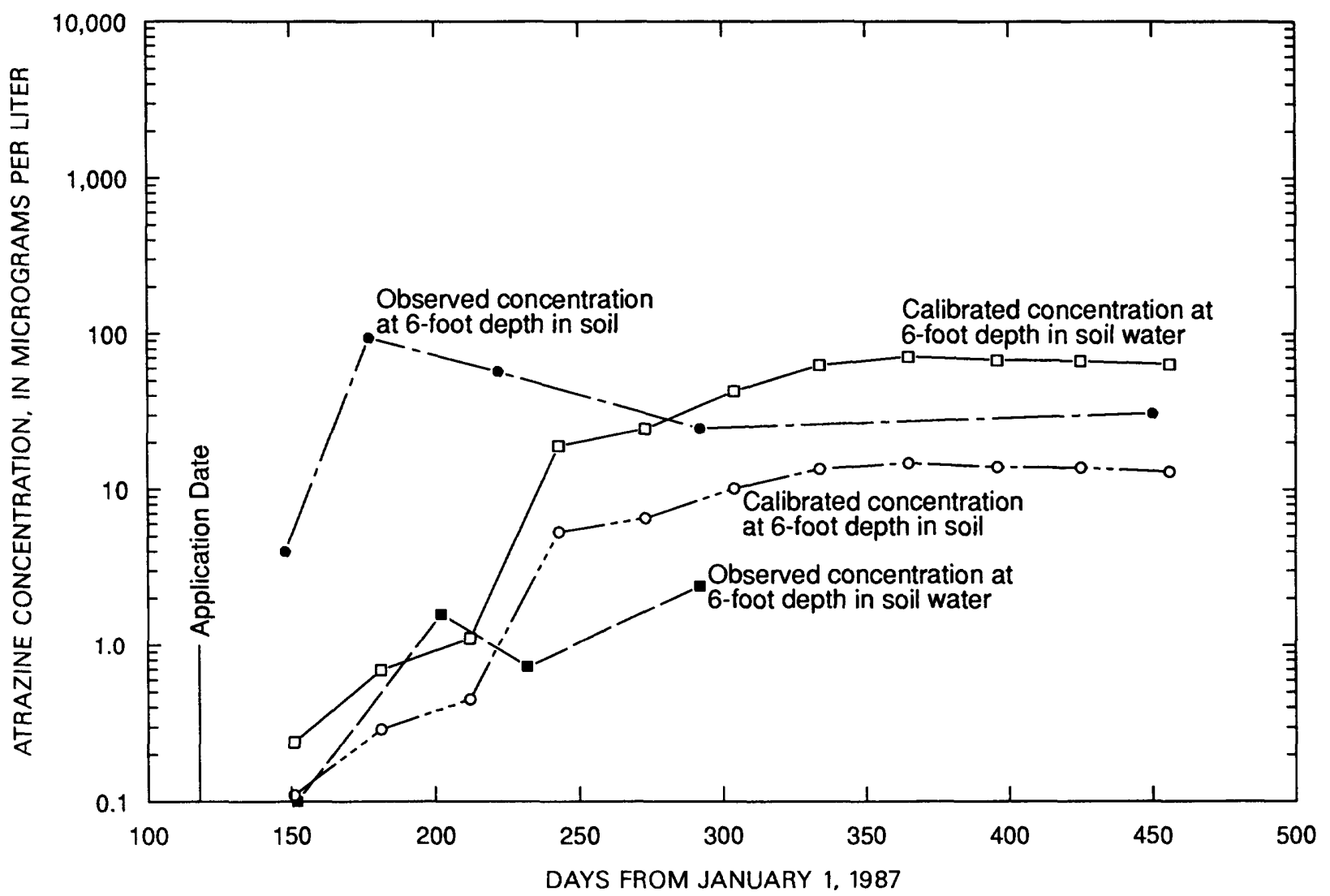

Figure 13. Observed and calibrated atrazine concentrations in soil and soil water at 6-foot depth at sandy loam site (site 2, fig. 1).

Total precipitation for each soil type was varied between one-half and twice the 37.64-inch amount. An example of this simulation for soilwater concentrations is shown in figure 19 for the 6-foot depth in the silty loam. When precipitation decreased by one-half, there was virtually no leaching of atrazine in any soil. When precipitation was doubled, the peak concentrations increased by one order of magnitude, and the transport time of the peak concentration was decreased by 70 percent of what it had been for 37.64 inches of precipitation. Also shown in figure 19 is the effect of doubling the atrazine-application rate with 37.64 inches of precipitation. In this case, the peak concentration was only doubled. Therefore, doubling the precipitation (or applied water in irrigation) increases the leaching of a herbicide much more than doubling the herbicideapplication rate.

\section{Atrazine Application by Chemigation}

A similar response was observed in the model simulations of chemigation. For each of the three soil types, figures $20-22$ show the leaching simulation using: (1) near-normal precipitation, no irrigation, and one application of 3.4 pounds per acre of atrazine per year; (2) near-normal precipitation plus 12 inches of irrigation during the growing season, and three equal applications of atrazine totaling 3.4 pounds per acre; and (3) near-normal precipitation plus 32 inches of irrigation and three equal applications of atrazine totaling 3.4 pounds per acre. Application dates and amounts are given in table 13. Even though the application of 12 inches of irrigation water represented a 32-percent increase in water in flux at land surface, atrazine concentrations of all three soil types increased by a factor of 5.6 at the 6-foot depth after 2 years when compared to the nonirrigated simulation. At the 16 -foot depth, the increase was greater than two orders of magnitude. The relative differences between the three soil types for both the 6- and 16-foot depths are shown in figure 23. The clay and the silty loam have similar responses, but atrazine concentrations in the soil water in the sandy loam are quite large. 
ORGANIC-CARBON CONTENT,

\section{IN PERCENT}

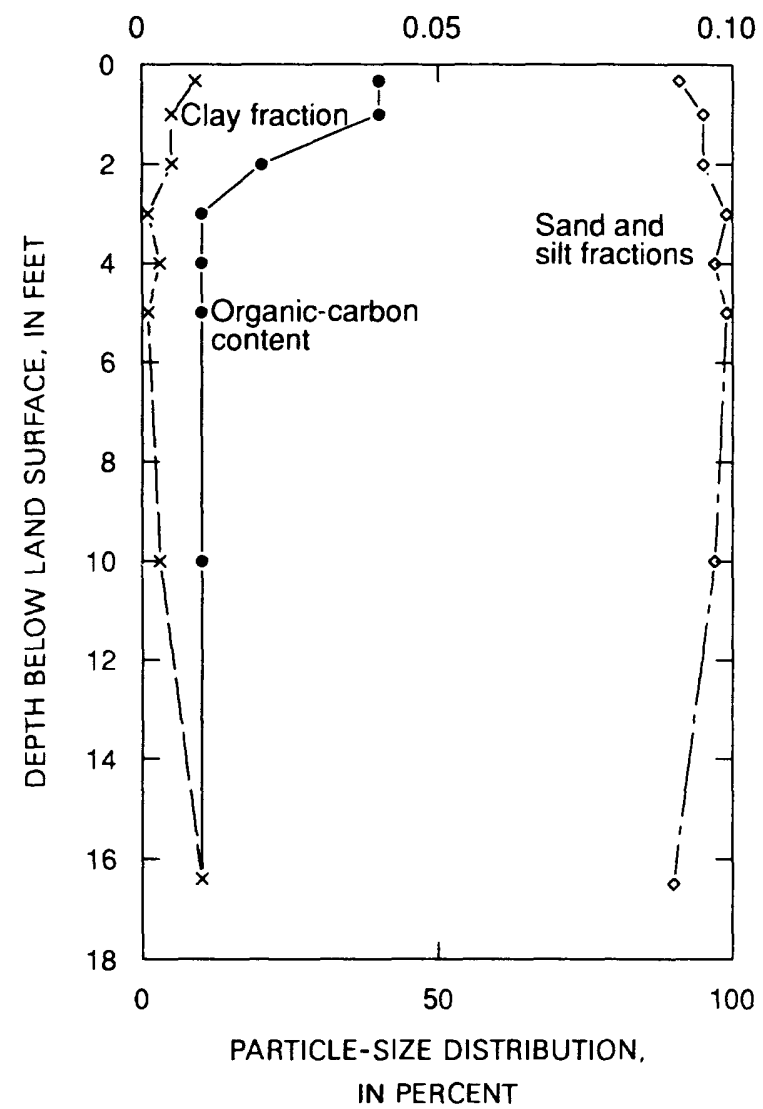

Figure 14. Soil particle-size distribution and organic-carbon content for PRZM simulations of sandy loam.

\section{Other Herbicides}

All of the model simulations for the various combinations of soil, precipitation, and chemigation options were run using atrazine as the herbicide. Other herbicides have chemical properties that either aid or retard leaching. Leached concentrations for four other herbicides were simulated using silty loam soil and nearnormal precipitation. The application rates, solubility, and half-lives for alachlor, atrazine, metolachlor, trifluralin, and 2,4-D are listed in table 14. Half-lives of alachlor, atrazine, metolachlor, trifluralin, and 2,4-D for various depths were estimated using data from Perry and others (1988) and Perry (1990). Application rates were equalized to improve observation of the differences in solubility and half-life. The previous simulations of atrazine showed that the leached herbicide concentrations double when the application rate is doubled.
ORGANIC-CARBON CONTENT,

IN PERCENT

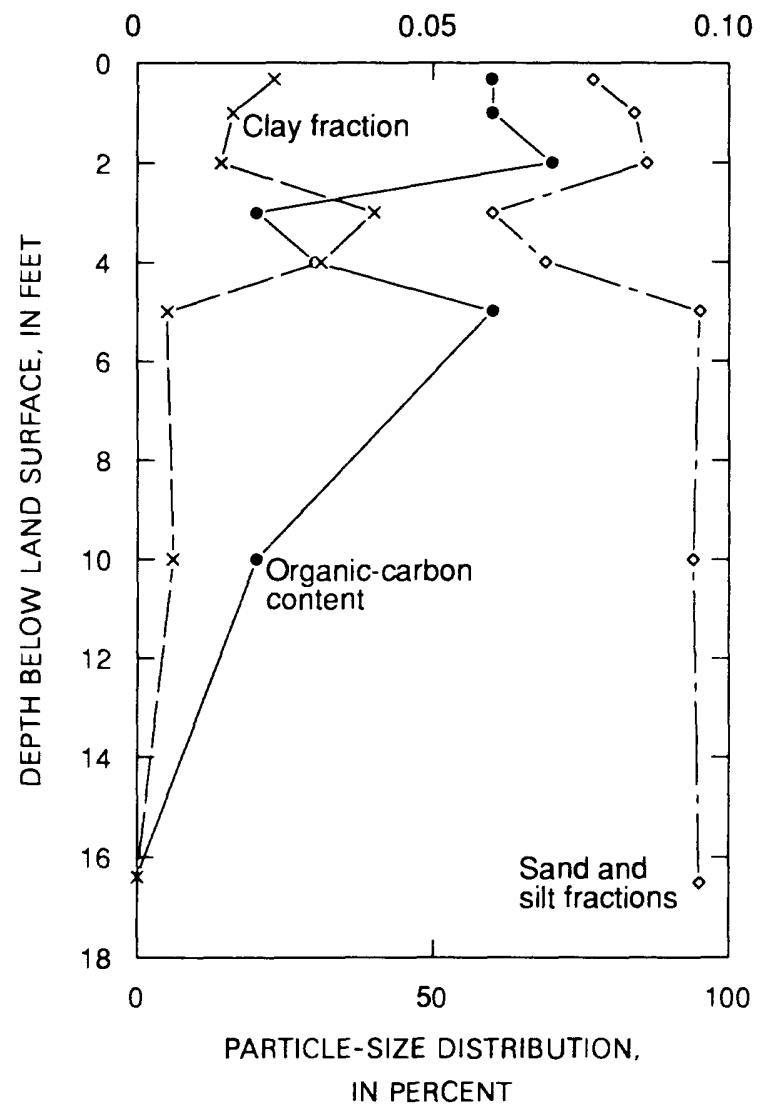

Figure 15. Soil particle-size distribution and organic-carbon content for PRZM simulations of clay.

Results of the simulations for the 6-foot depth are shown in figure 24. The 2,4-D, which has a very small solubility and short half-life, did not leach to the 6-foot depth. A trace of trifluralin $(0.20 \mu \mathrm{g} / \mathrm{L})$ was detected in the soil water after 2 years. Solubility for trifluralin is small, but its half-life was estimated to be almost that of alachlor and metolachlor. Atrazine, with its $70-\mathrm{mg} / \mathrm{L}$ solubility, was leached because of its much longer half-life. Atrazine concentrations were slow to increase at the 6-foot depth but continued to increase throughout the 2-year simulation. Alachlor concentrations increased more quickly than atrazine concentrations, but not as rapidly as metolachlor, which is the most soluble of the five herbicides simulated. Although the half-life of metolachlor is about one-half that of alachlor, metolachlor's larger solubility (2.4 times) allows it to reach a concentration that is 1.4 times that of alachlor after the first year. The simulated alachlor 


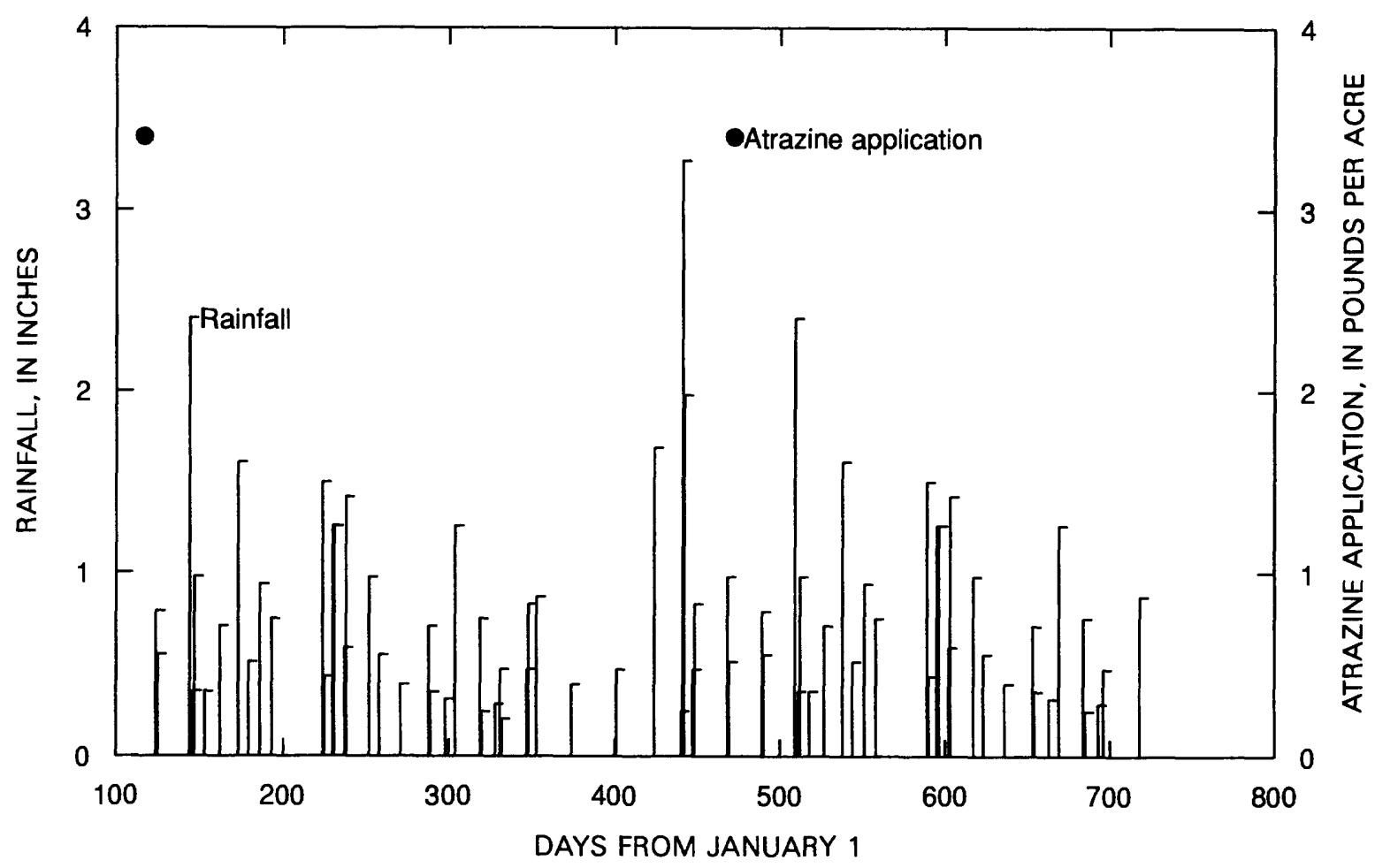

Figure 16. Rainfall and atrazine-application amounts and dates for PRZM simulations.

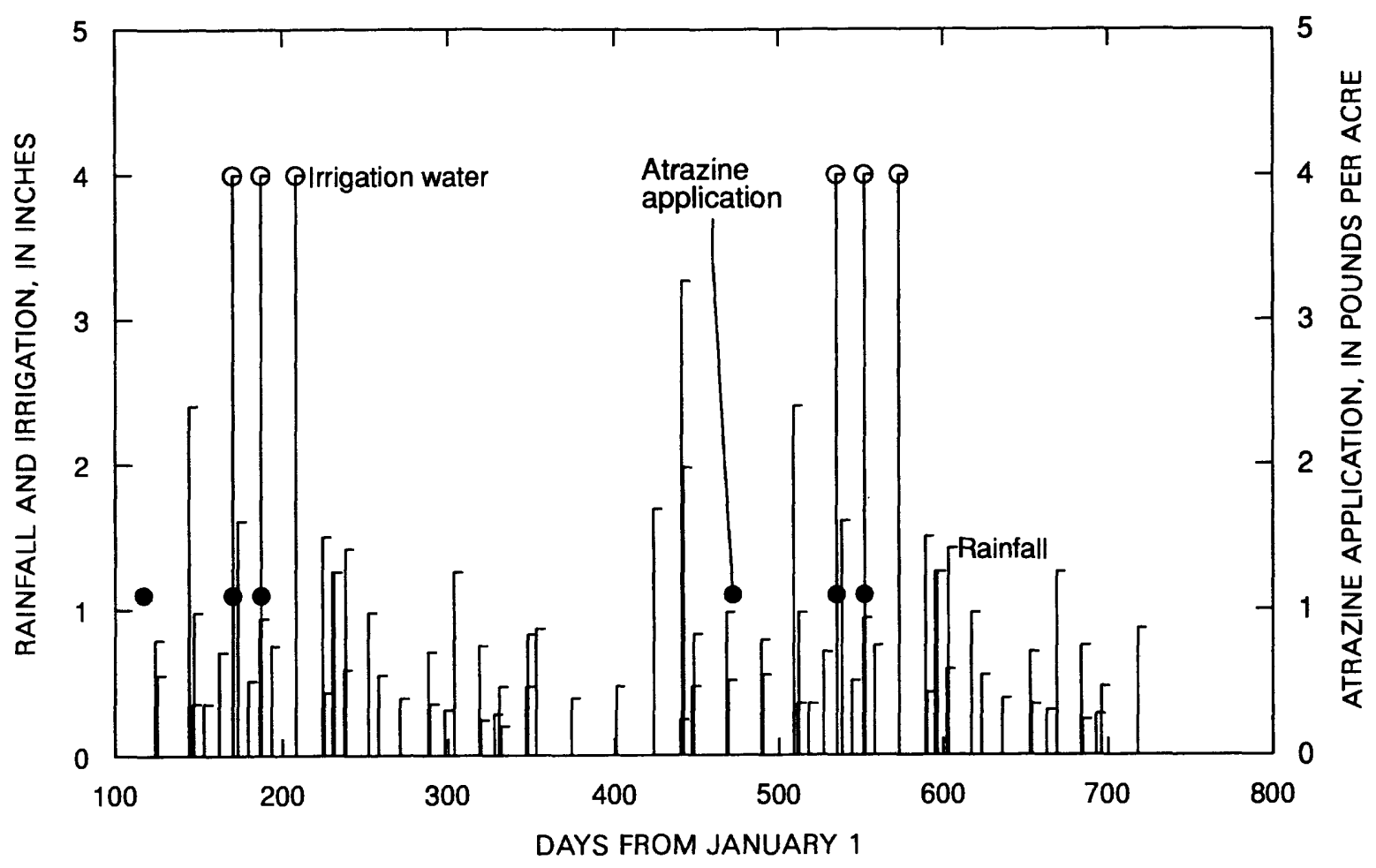

Figure 17. Rainfall plus irrigation and atrazine-application amounts and dates for 12-inch chemigation simulations. 


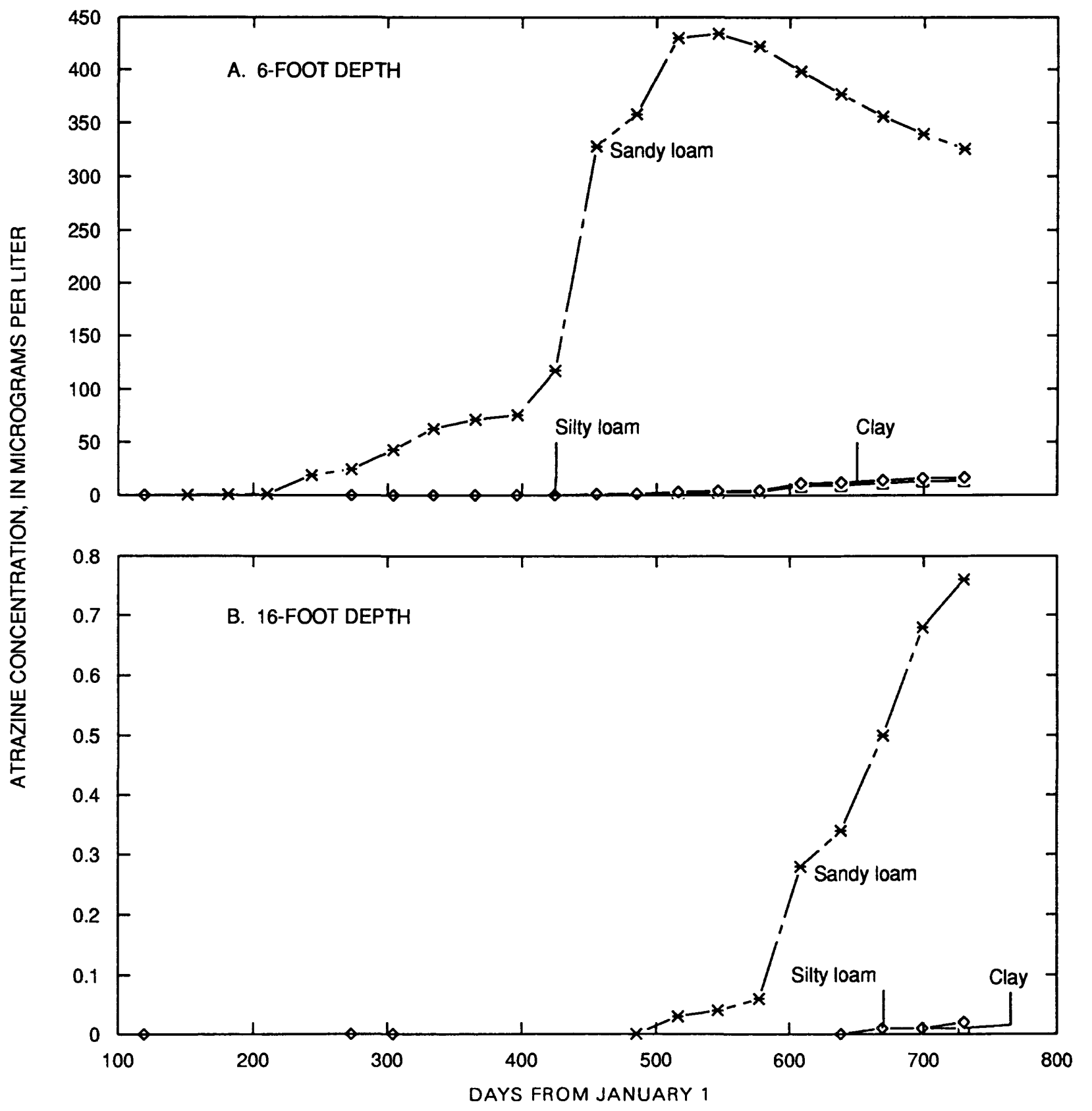

Figure 18. Simulated atrazine concentrations in soil water in silty loam, sandy loam, and clay at (A) 6-foot and (B) 16-foot depths.

concentrations were slower to increase than the metolachlor concentrations, but the longer halflife of alachlor allowed it to reach a concentration in soil water nearly twice that of the metolachlor concentration after 2 years. Concentrations of herbicides in soil water in the three soil types for the 6-foot and 16-foot depths under various precipitation and irrigation conditions are listed in table 15.

\section{IMPLICATIONS FOR LEACH APPLICATION}

The "Leaching Evaluation of Agricultural Chemicals Handbook" (LEACH) was developed using the PRZM for a long-term simulation (25 years) of annual pesticide leaching. The user of LEACH must evaluate key variables for a pesticide-site and crop-management scenario to determine the pesticide-leaching cumulativefrequency distributions.

The problems encountered in calibrating the PRZM to the data collected and evaluated in this report indicates that $\mathrm{LEACH}$ can be used for 


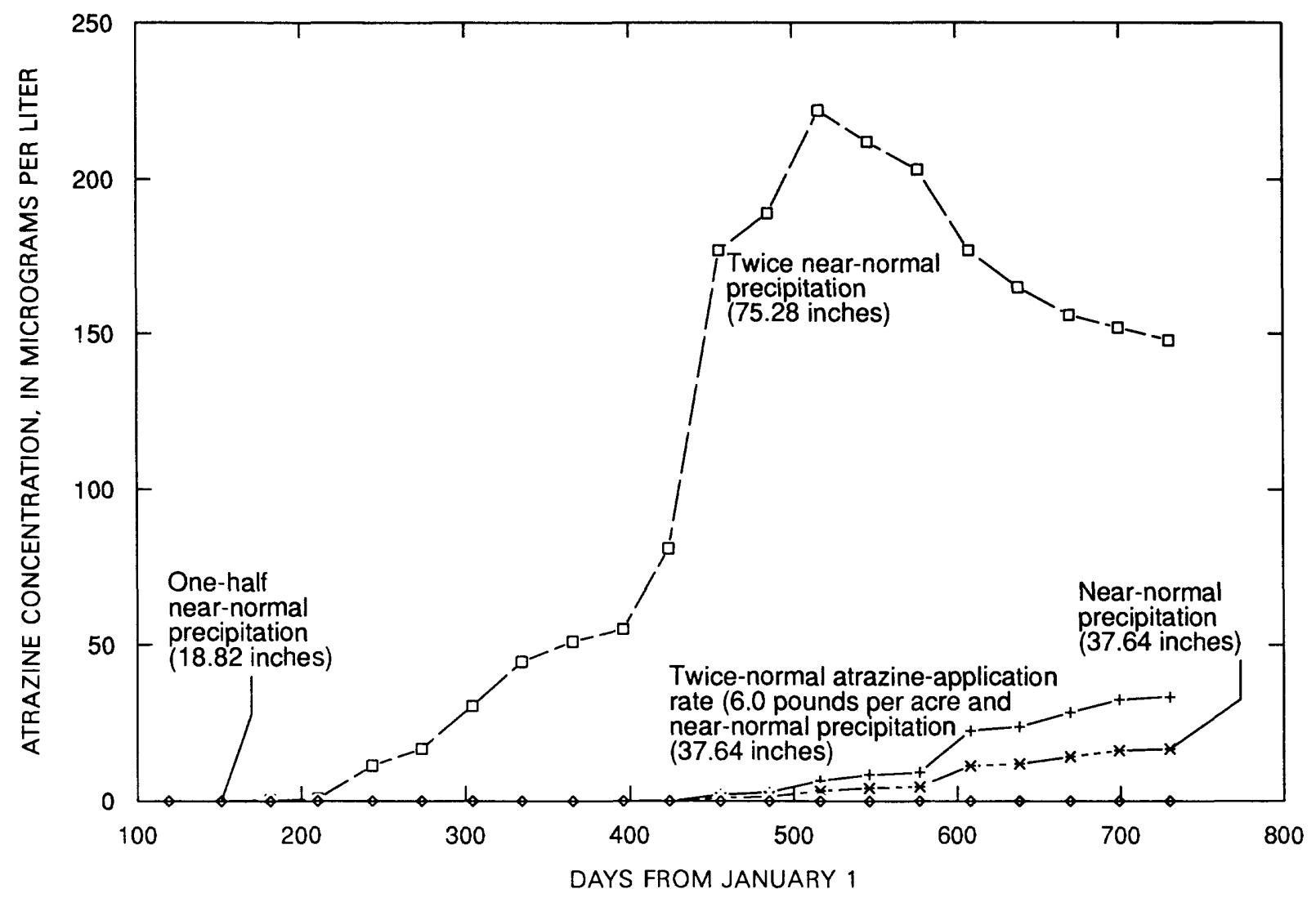

Figure 19. Simulated atrazine concentrations in soil water in silty loam at 6-foot depth with onehalf, twice, and near-normal precipitation, and twice-normal atrazine-application rate.

the evaluation of pesticide leachability if appropriate adjustments to input data are made. These adjustments are: (1) Including the silt fraction in the sand fraction in the soil-texture classification; (2) decreasing the apparent organic-carbon concentration of the soil by multiplying the observed concentration by 0.1 ; and $(3)$ increasing the half-life of the pesticide in question to at least the maximum published value. Without these adjustments, LEACH will underestimate the percentage of applied pesticide that moves below the root zone.

LEACH computations were made for the three sites using unadjusted and adjusted input parameters. The adjusted parameters were: (1) including the silt fraction in the sand fraction and (2) decreasing organic-carbon concentration by a factor of 0.1 . For this comparison, the halflife of the pesticide was not changed. These adjustments resulted in a retardation factor $(R)$ at each site that was approximately 25 percent of the unadjusted value. The decrease in the value of $R$ resulted in an increase in the percentage of pesticide leached per year for a given percentage of time exceeded. For instance, for a cornfield in Kansas with a Soil Conservation Service infiltration-curve number of 77 , the amount of pesticide leached 50 percent of the time increased by a factor of approximately 5 when $R$ was decreased from a value of 5 to 1 .

\section{SUMMARY}

Experimental leaching sites, reflecting three soil types and five applied herbicides that are characteristic of the State's agricultural regions, were developed at the Kansas River Valley Experimental Farm near Topeka, Kansas, during 1986-88. The distribution and movement of five herbicides, alachlor, atrazine, metolachlor, trifluralin, and 2,4-D, were measured in the unsaturated zone using ring lysimeters that received varying amounts of rainfall and irrigation water.

Leaching experiments were designed to obtain information on herbicide concentrations at various depths in the unsaturated zone. The assumption that the process of chemical leaching 


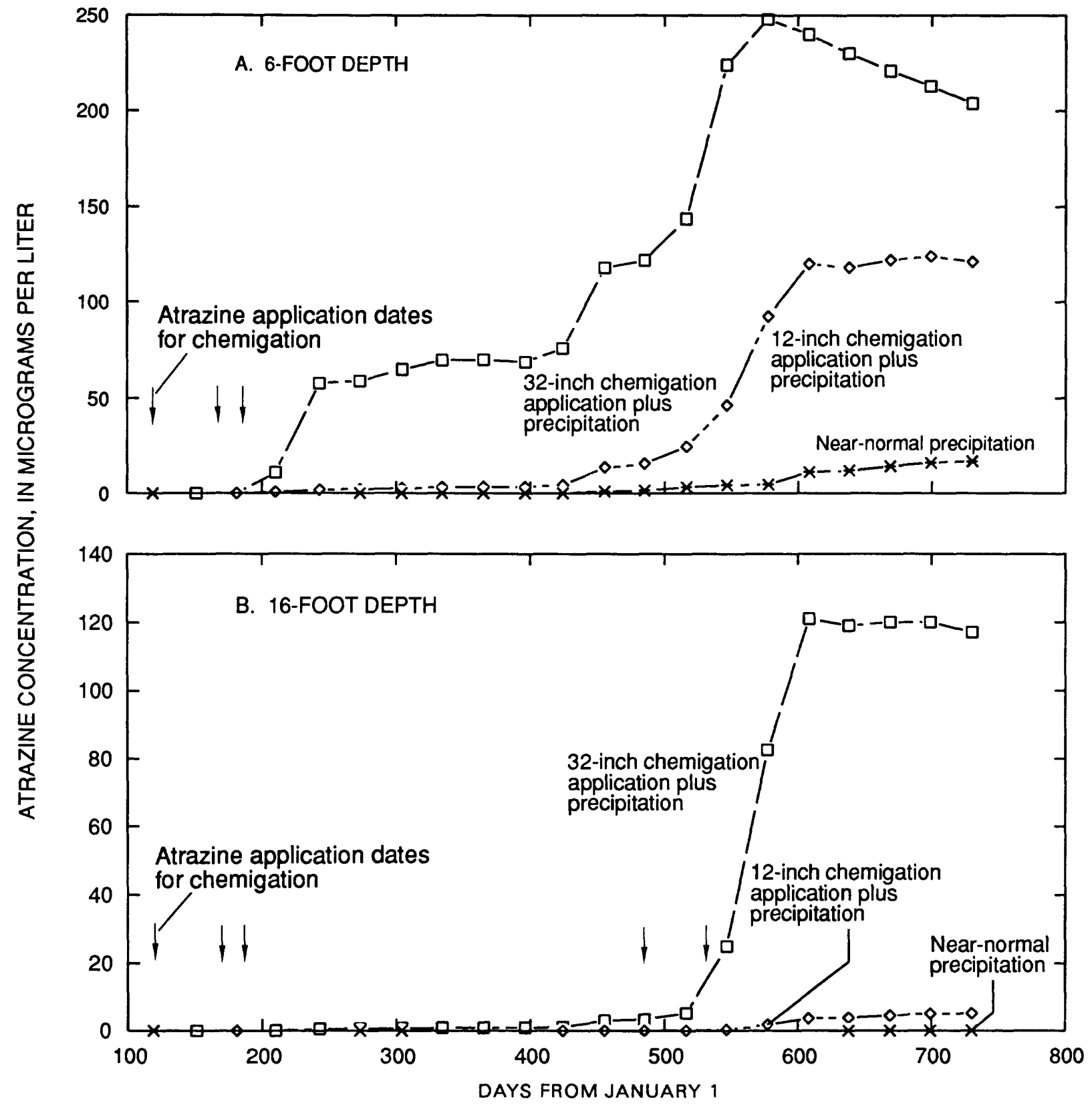

Figure 20. Simulated atrazine concentrations in soil water in silty loam at (A) 6-foot and (B) 16-foot depths for near-normal precipitation with conventional herbicide application, and 12-inch and 32inch chemigation applications.

operates in a discontinuous manner in a nonhomogeneous medium, as affected by an impulsive transporting mechanism, was followed in the choice and subsequent revisions of the experiment design.

In this experiment, two major factors affecting herbicide movement were eliminated. They were surface-water runoff and plant uptake. These two factors often are used as correction factors in most modeling efforts, and their elimination allowed a greater degree of focus on the movement and persistence of herbicides through the unsaturated soil profile.

Most of the data on herbicide leaching gathered in this investigation involved the use of ring lysimeters. These were open-bottomed 

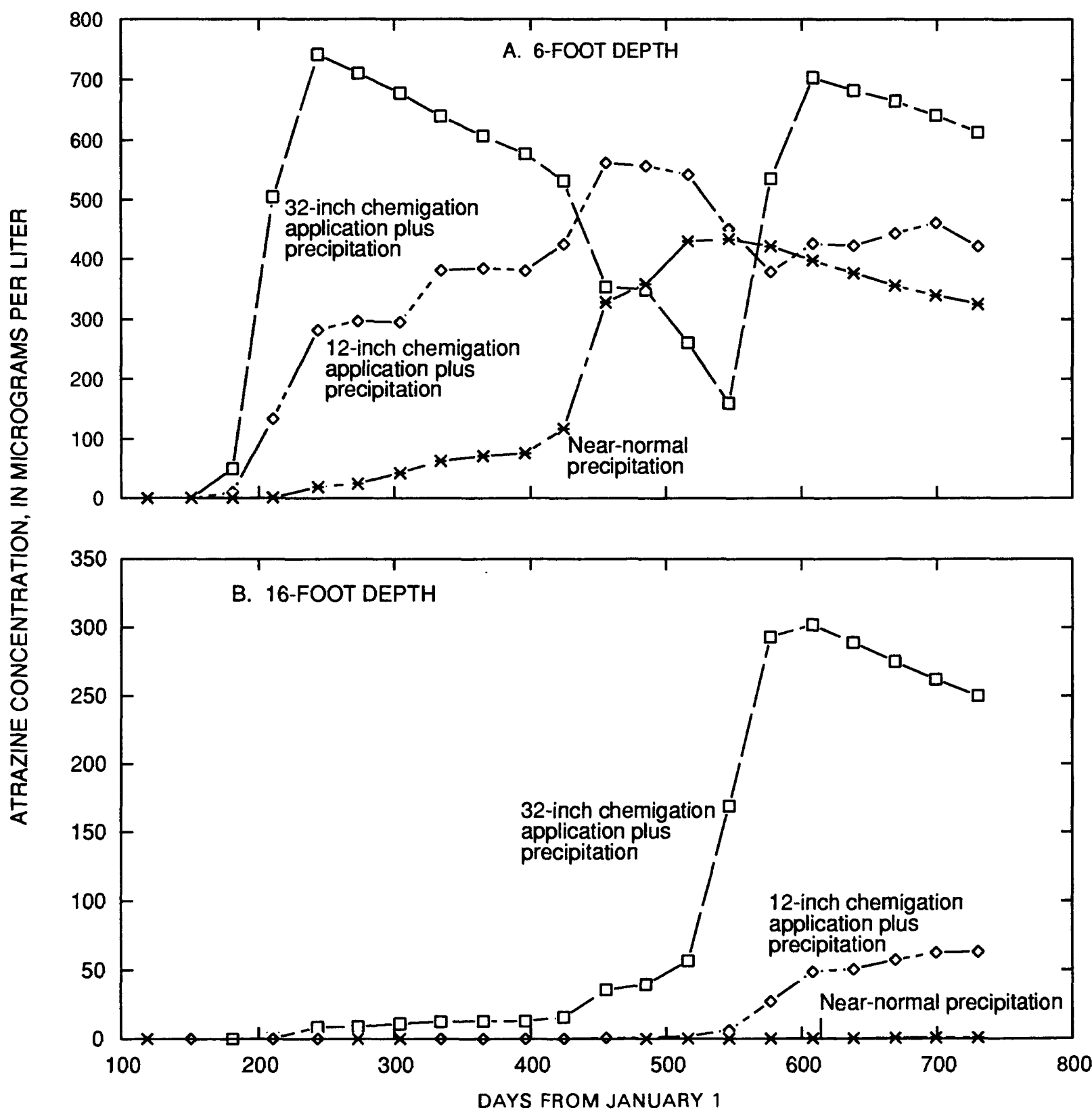

Figure 21. Simulated atrazine concentrations in soil water in sandy loam at (A) 6-foot and (B) 16foot depths for near-normal precipitation with conventional herbicide application, and 12-inch and 32-inch chemigation applications.

lysimeters constructed of 1/16-inch steel, rolled into a cylinder, and arc-welded at the seam. The cylinder was 3 feet in diameter and 3 feet high. In March 1986, 14 ring lysimeters were installed in silty loam soil at a location on the farm that had had no herbicide application for at least 10 years. The rings were arranged so that seven of them could be irrigated. Both groups of seven ring lysimeters had the same series of herbicides applied on April 29, 1986, and were monitored ifor nearly 2 years. The five herbicides nvestigated and their respective rates of application were: alachlor, 2 quarts per acre; atrazine, 1.5 and 3.0 pounds per acre; metolachlor, 1 quart per acre; trifluralin, 1 quart per acre; and 2,4-D, 1 quart per acre. The seventh ring received atrazine at 1.5 pounds per acre. This ring had suction lysimeters installed at depths of $2,3,4$, and 6 feet below the ground surface. 


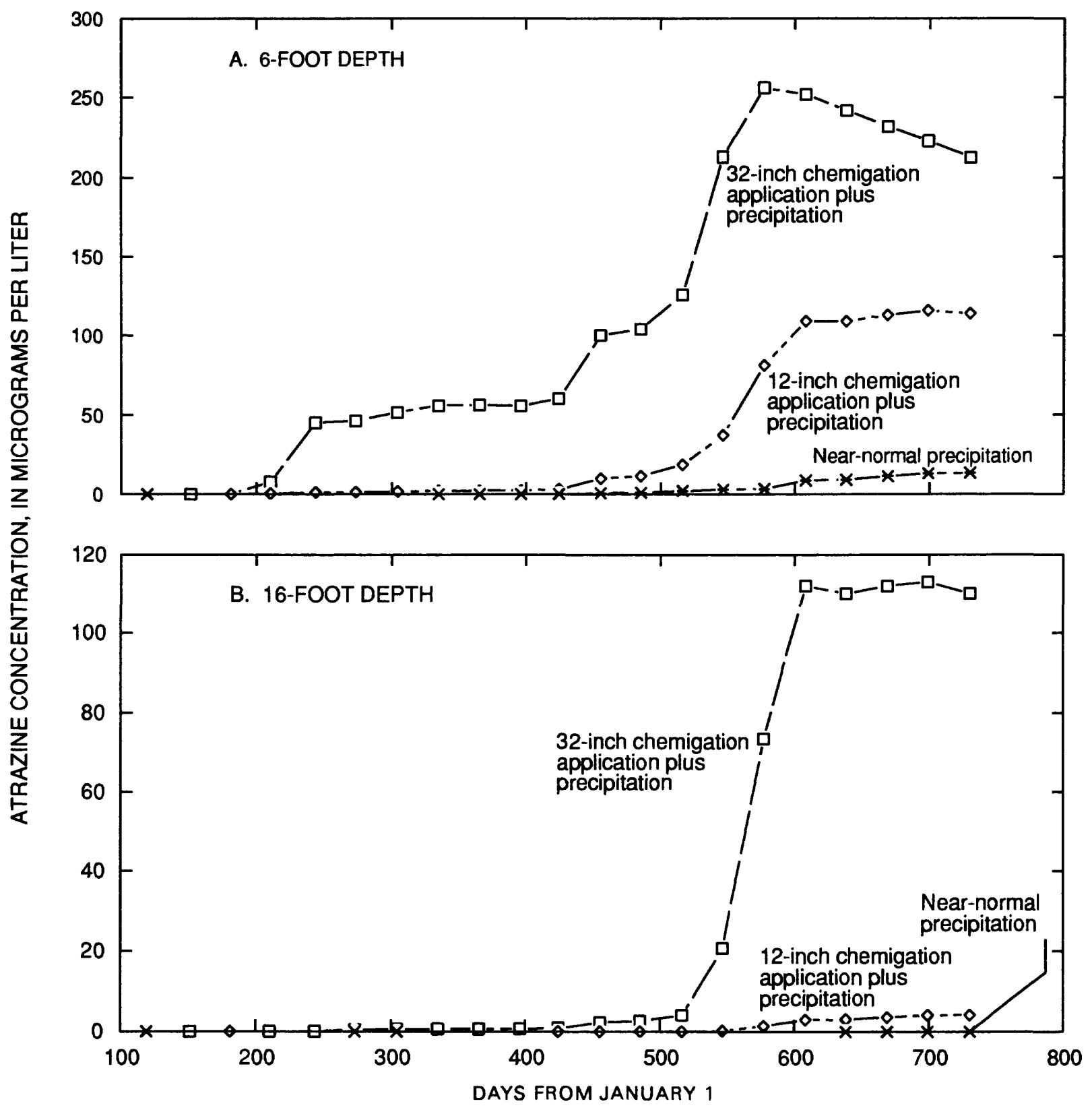

Figure 22. Simulated atrazine concentrations in soil water in clay at (A) 6-foot and (B) 16-foot depths for near-normal precipitation with conventional herbicide application, and 12-inch and 32inch chemigation applications.

Data describing the chemical concentrations of the herbicides were collected in conjunction with various other environmental data. These data included physical and chemical properties of the soil, soil-water content, rainfall, irrigation-water depths, meteorological factors used in estimating potential evapotranspiration, and depth to the water table.

Analyses of 1986 soil cores and soil-water samples for atrazine indicated no significant differences between the irrigated and nonirrigated lysimeters. Trifluralin concentrations were larger in the nonirrigated lysimeters. Concentrations of alachlor, metolachlor, and 2,4-D were not detected in the 1986 samples. Rainfall and irrigation water appeared to have moved the atrazine and trifluralin in the unsaturated zone in pulses. Trifluralin was still detected after nearly 1 year 
Table 13. Atrazine and irrigation-application variations for PRZM simulations

\begin{tabular}{|c|c|c|c|}
\hline Type of application & $\begin{array}{c}\text { Application } \\
\text { day (from } \\
\text { Jan. 1, first } \\
\text { year) }\end{array}$ & $\begin{array}{l}\text { Amount of } \\
\text { atrazine } \\
\text { (pounds per } \\
\text { acre) }\end{array}$ & $\begin{array}{l}\text { Amount of } \\
\text { irrigation } \\
\text { (inches) }\end{array}$ \\
\hline \multirow[t]{2}{*}{ Conventional } & 118 & 3.4 & 0 \\
\hline & 483 & 3.4 & 0 \\
\hline \multirow[t]{8}{*}{12 -inch chemigation } & 118 & 1.2 & 0 \\
\hline & 172 & 1.1 & 4.0 \\
\hline & 187 & 1.1 & 4.0 \\
\hline & 208 & $\mathbf{0}$ & 4.0 \\
\hline & 483 & 1.2 & $\mathbf{0}$ \\
\hline & 537 & 1.1 & 4.0 \\
\hline & 552 & 1.1 & 4.0 \\
\hline & 573 & 0 & 4.0 \\
\hline \multirow[t]{18}{*}{ 32-inch chemigation } & 118 & 1.2 & $\mathbf{0}$ \\
\hline & 172 & 1.1 & 4.0 \\
\hline & 180 & 0 & 4.0 \\
\hline & 187 & 1.1 & 4.0 \\
\hline & 194 & 0 & 4.0 \\
\hline & 201 & 0 & 4.0 \\
\hline & 208 & 0 & 4.0 \\
\hline & 215 & $\mathbf{0}$ & 4.0 \\
\hline & 222 & 0 & 4.0 \\
\hline & 483 & 1.2 & 0 \\
\hline & 537 & 1.1 & 4.0 \\
\hline & 545 & 0 & 4.0 \\
\hline & 552 & 1.1 & 4.0 \\
\hline & 559 & $\mathbf{0}$ & 4.0 \\
\hline & 566 & $\mathbf{0}$ & 4.0 \\
\hline & 573 & $\mathbf{0}$ & 4.0 \\
\hline & 580 & 0 & 4.0 \\
\hline & 587 & 0 & 4.0 \\
\hline
\end{tabular}




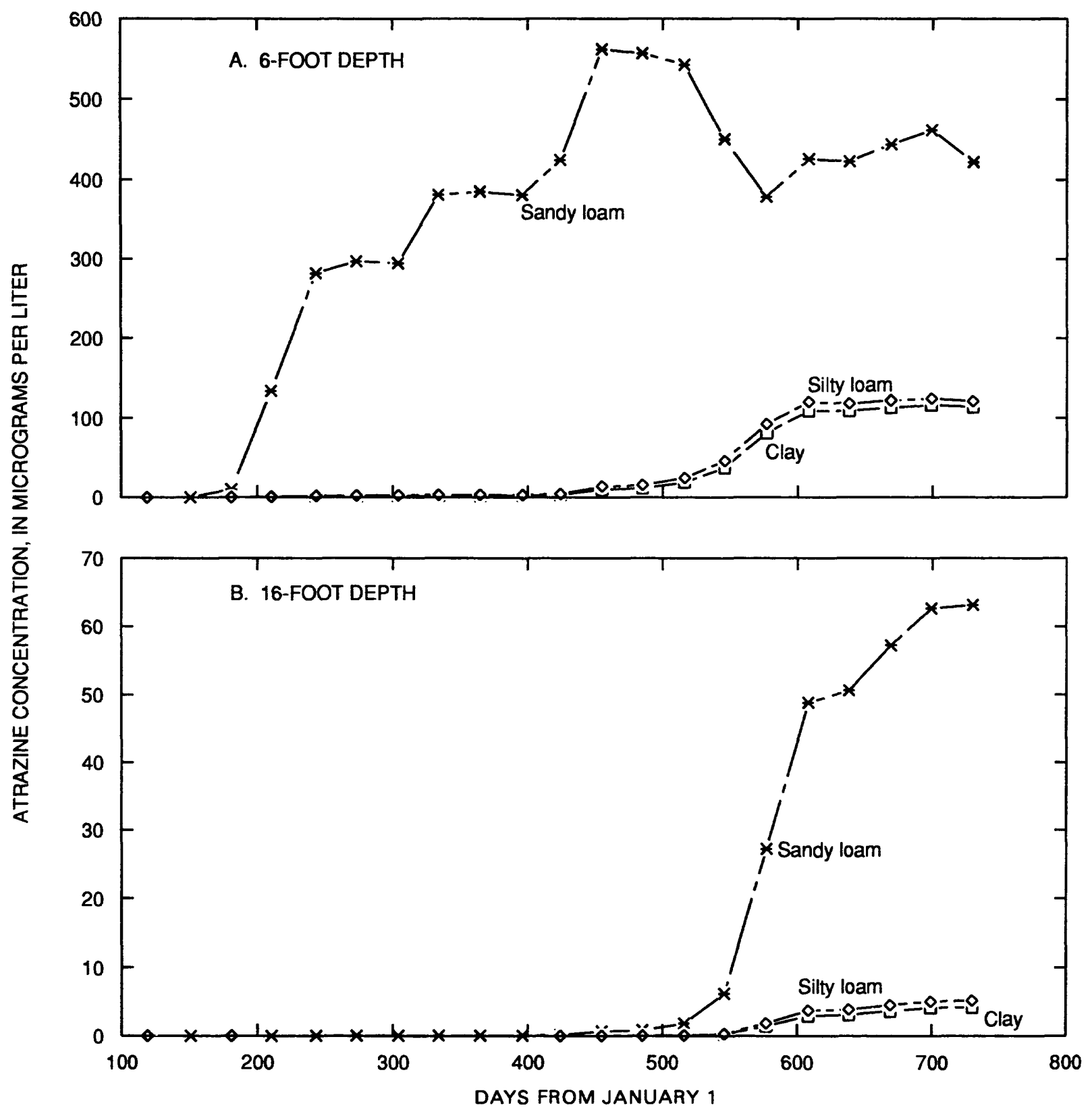

Figure 23. Simulated atrazine concentrations in soil water in silty loam, sandy loam, and clay at (A) 6-foot and (B) 16-foot depths for 12-inch chemigation application.

and atrazine after nearly 2 years. Atrazine, with the larger solubility and longer half-life, moved through the soil profile quicker than had been expected. The scheduled sample collection was apparently too infrequent, and peak values in herbicide concentrations in the shallow layers were missed. The sampling was improved in the 1987 experiment.

The 1987 ring-lysimeter experiment began on April 29, 1987, with the application of the five herbicides, alachlor, atrazine, metolachlor, trifluralin, 2,4-D, and the tracer potassium chloride applied at a rate of $\mathbf{2 0 0}$ pounds per acre, on three sets of ring lysimeters representing three soil types. The 1987 soil cores were collected continuously from the surface to 6 feet to improve definition of herbicide distributions. The soil cores and the suction lysimeters were sampled more frequently than 


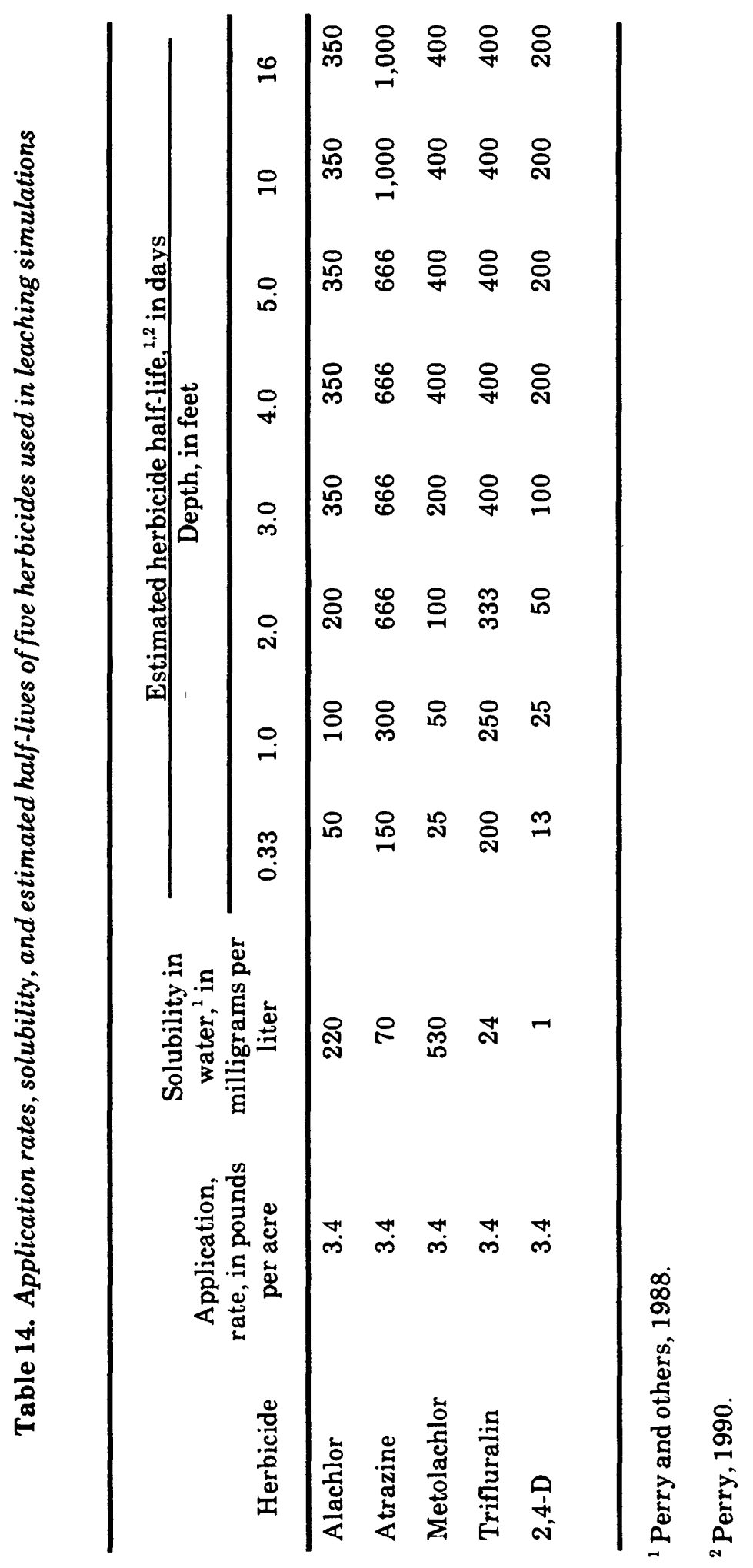




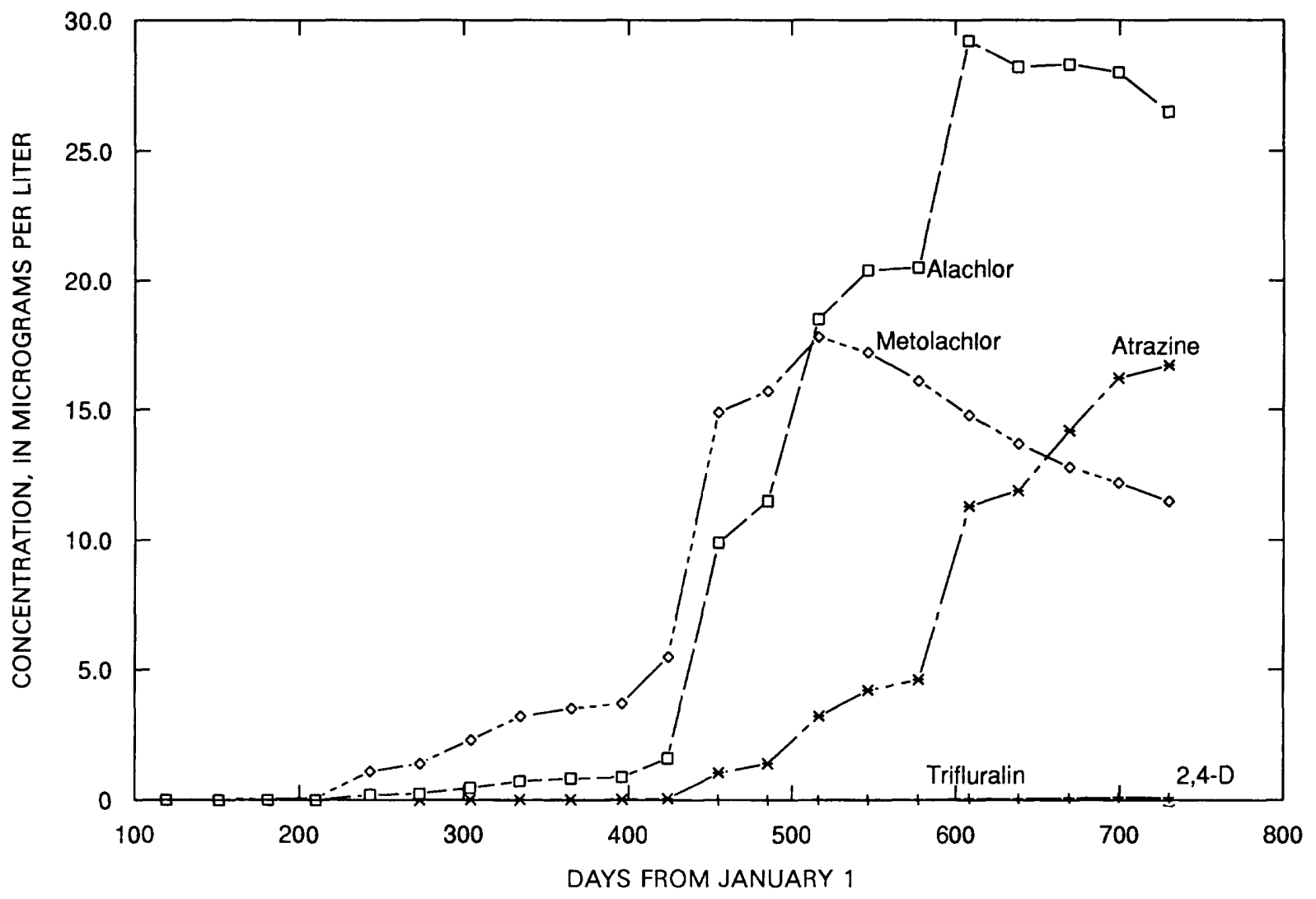

Figure 24. Simulated alachlor, atrazine, metolachlor, trifluralin, and 2,4-D concentrations in soil water in silty loam at 6-foot depth with near-normal precipitation.

in 1986. In addition, the chloride analyses provided an indicator for movement of water through the unsaturated zone.

The task of calibrating the Pesticide Root Zone Model (PRZM) was accomplished using the more detailed 1987-88 data. The modeling effort was accomplished in two steps of comparing simulated chloride and herbicide concentrations with observed concentrations. In the first step, actual measured data were used for the input parameters. In the second step, a systematic adjustment was made to the input data for all three soil types to calibrate the simulated concentrations to the observed concentrations at 2-, 3-, 4-, and 6-foot depths in all three soil types.

In the first step, simulated concentrations for the conservative tracer, potassium chloride, were compared to the observed concentrations in soil water for the silty loam, sandy loam, and clay. There was no correlation $(R=0)$ between the observed and simulated chloride concentrations. The failure of the model to match the observed chloride concentrations may be due in part to the lack of consideration of macropore flow.

The PRZM was calibrated by systematically adjusting input parameters. The elimination of surface-water-runoff and plantuptake components left only the soil parameters and chemical properties to be modified. Of the soil parameters, only the sand and clay fractions and the organic-carbon content were adjusted. The only chemical parameter to be adjusted was the herbicide half-life. In all model simulations, soil moisture was initialized at a value of field capacity, then allowed to equilibrate with the observed precipitation and evapotranspiration. Particle-size distribution was adjusted to include the silt fraction in the sand fraction. In this manner, the model does not compute a silt fraction resulting in a more permeable soil. In comparing calibrated and observed chloride concentrations, the correlation coefficient was 
Table 15. Results of leaching simulations

\begin{tabular}{|c|c|c|c|c|c|c|c|c|}
\hline \multirow{3}{*}{$\begin{array}{c}\text { Day (from } \\
\text { Jan. 1, first } \\
\text { year) }\end{array}$} & \multicolumn{8}{|c|}{ Atrazine concentrations in soil water in silty loam, in micrograms per liter } \\
\hline & \multicolumn{2}{|c|}{$\begin{array}{l}\text { Near-normal } \\
\text { precipitation } \\
(37.64 \text { inches) }\end{array}$} & \multicolumn{2}{|c|}{$\begin{array}{l}\text { One-half near- } \\
\text { normal } \\
\text { precipitation } \\
\text { (18.82 inches) }\end{array}$} & \multicolumn{2}{|c|}{$\begin{array}{l}\text { Twice near-normal } \\
\text { precipitation } \\
\text { (75.28 inches) }\end{array}$} & \multicolumn{2}{|c|}{$\begin{array}{l}\text { Twice-normal } \\
\text { atrazine- } \\
\text { application rate } \\
\text { (6.8 pounds per } \\
\text { acre) }\end{array}$} \\
\hline & $\begin{array}{l}\text { 6-foot } \\
\text { depth }\end{array}$ & $\begin{array}{l}\text { 16-foot } \\
\text { depth }\end{array}$ & $\begin{array}{l}\text { 6-foot } \\
\text { depth }\end{array}$ & $\begin{array}{l}\text { 16-foot } \\
\text { depth }\end{array}$ & $\begin{array}{l}\text { 6-foot } \\
\text { depth }\end{array}$ & $\begin{array}{l}\text { 16-foot } \\
\text { depth }\end{array}$ & $\begin{array}{l}\text { 6-foot } \\
\text { depth }\end{array}$ & $\begin{array}{c}\text { 16-foot } \\
\text { depth }\end{array}$ \\
\hline 119 & 0 & 0 & 0 & 0 & 0 & 0 & 0 & 0 \\
\hline 151 & 0 & 0 & 0 & 0 & .09 & 0 & 0 & 0 \\
\hline 181 & 0 & 0 & 0 & 0 & .36 & 0 & $\mathbf{0}$ & 0 \\
\hline 210 & 0 & 0 & 0 & 0 & .68 & 0 & 0 & 0 \\
\hline 243 & 0 & 0 & 0 & 0 & 11 & · $\quad .02$ & 0 & 0 \\
\hline 273 & 0 & 0 & 0 & 0 & 17 & .03 & 0 & 0 \\
\hline 304 & 0.01 & 0 & 0 & 0 & 30 & .08 & .02 & 0 \\
\hline 334 & .02 & 0 & 0 & 0 & 44 & .16 & .04 & 0 \\
\hline 365 & .02 & 0 & 0 & 0 & 51 & .21 & .05 & 0 \\
\hline 396 & .03 & 0 & 0 & 0 & 55 & .25 & .05 & 0 \\
\hline 424 & .06 & 0 & 0 & 0 & 81 & .70 & .12 & 0 \\
\hline 455 & 1.0 & 0 & 0 & 0 & 180 & 9.8 & 2.1 & 0 \\
\hline 485 & 1.4 & 0 & 0 & 0 & 190 & 13 & 2.8 & 0 \\
\hline 516 & 3.2 & 0 & 0 & 0 & 220 & 32 & 6.5 & 0 \\
\hline 546 & 4.2 & 0 & 0 & 0 & 210 & 44 & 8.4 & 0 \\
\hline 577 & 4.6 & 0 & 0 & 0 & 200 & 51 & 9.2 & 0 \\
\hline 608 & 11 & 0 & 0 & 0 & 180 & 98 & 23 & .01 \\
\hline 638 & 12 & 0 & 0 & 0 & 160 & 100 & 24 & .01 \\
\hline 669 & 14 & 0.01 & 0 & 0 & 160 & 120 & 28 & .02 \\
\hline 699 & 16 & .01 & 0 & 0 & 150 & 120 & 32 & .02 \\
\hline 730 & 17 & .02 & 0 & 0 & 150 & 120 & 33 & .04 \\
\hline
\end{tabular}


Table 15. Results of leaching simulations--Continued

\begin{tabular}{|c|c|c|c|c|c|c|}
\hline \multirow[b]{3}{*}{$\begin{array}{c}\text { Day (from Jan. } \\
1, \text { first year) }\end{array}$} & \multicolumn{6}{|c|}{$\begin{array}{l}\text { Atrazine concentrations in soil water with near-normal precipitation } \\
\text { (37.64 inches), in micrograms per liter }\end{array}$} \\
\hline & \multicolumn{2}{|c|}{ Silty loam } & \multicolumn{2}{|c|}{ Sandy loam } & \multicolumn{2}{|c|}{ Clay } \\
\hline & $\begin{array}{l}\text { 6-foot } \\
\text { depth }\end{array}$ & $\begin{array}{l}\text { 16-foot } \\
\text { depth }\end{array}$ & $\begin{array}{l}6 \text {-foot } \\
\text { depth }\end{array}$ & $\begin{array}{l}\text { 16-foot } \\
\text { depth }\end{array}$ & $\begin{array}{l}\text { 6-foot } \\
\text { depth }\end{array}$ & $\begin{array}{l}\text { 16-foot } \\
\text { depth }\end{array}$ \\
\hline 119 & 0 & 0 & 0 & 0 & 0 & 0 \\
\hline 151 & 0 & 0 & .24 & 0 & 0 & 0 \\
\hline 181 & 0 & 0 & .69 & 0 & 0 & 0 \\
\hline 210 & 0 & 0 & 1.0 & 0 & 0 & 0 \\
\hline 243 & 0 & 0 & 19 & 0 & 0 & 0 \\
\hline 273 & 0 & 0 & 24 & 0 & 0 & 0 \\
\hline 304 & .01 & 0 & 43 & 0 & 0 & 0 \\
\hline 334 & .02 & 0 & 63 & 0 & 0 & 0 \\
\hline 365 & .02 & 0 & 71 & 0 & .01 & 0 \\
\hline 396 & .03 & 0 & 76 & 0 & .02 & 0 \\
\hline 424 & .06 & 0 & 120 & 0 & .04 & 0 \\
\hline 455 & 1.0 & 0 & 330 & 0 & .69 & 0 \\
\hline 485 & 1.4 & 0 & 360 & 0 & .93 & 0 \\
\hline 516 & 3.2 & 0 & 430 & .03 & 2.3 & 0 \\
\hline 546 & 4.2 & 0 & 430 & .04 & 3.0 & 0 \\
\hline 577 & 4.6 & 0 & 420 & .06 & 3.4 & 0 \\
\hline 608 & 11 & 0 & 400 & .28 & 8.8 & 0 \\
\hline 638 & 12 & 0 & 380 & .34 & 9.3 & 0 \\
\hline 669 & 14 & .01 & 360 & .50 & 11 & 0 \\
\hline 699 & 16 & .01 & 340 & .68 & 13 & 0 \\
\hline 730 & 17 & .02 & 330 & .76 & 14 & .01 \\
\hline
\end{tabular}


Table 15. Results of leaching simulations--Continued

\begin{tabular}{|c|c|c|c|c|c|c|}
\hline \multirow[b]{3}{*}{$\begin{array}{l}\text { Day (from Jan. } \\
1, \text { first year) }\end{array}$} & \multicolumn{6}{|c|}{$\begin{array}{l}\text { Atrazine concentrations in soil water with one-half near-normal } \\
\text { precipitation ( } 18.82 \text { inches), in micrograms per liter }\end{array}$} \\
\hline & \multicolumn{2}{|c|}{ Silty loam } & \multicolumn{2}{|c|}{ Sandy loam } & \multicolumn{2}{|c|}{ Clay } \\
\hline & $\begin{array}{l}\text { 6-foot } \\
\text { depth }\end{array}$ & $\begin{array}{l}\text { 16-foot } \\
\text { depth }\end{array}$ & $\begin{array}{l}\text { 6-foot } \\
\text { depth }\end{array}$ & $\begin{array}{l}\text { 16-foot } \\
\text { depth }\end{array}$ & $\begin{array}{l}\text { 6-foot } \\
\text { depth }\end{array}$ & $\begin{array}{c}\text { 16-foot } \\
\text { depth }\end{array}$ \\
\hline 119 & 0 & 0 & 0 & 0 & 0 & 0 \\
\hline 151 & 0 & 0 & 0 & 0 & 0 & 0 \\
\hline 181 & 0 & 0 & 0 & 0 & 0 & $\mathbf{0}$ \\
\hline 210 & 0 & 0 & 0 & 0 & 0 & 0 \\
\hline 243 & 0 & 0 & 0 & $\mathbf{0}$ & 0 & 0 \\
\hline 273 & 0 & $\mathbf{0}$ & 0 & $\mathbf{0}$ & 0 & 0 \\
\hline 304 & 0 & 0 & 0 & 0 & 0 & 0 \\
\hline 334 & 0 & 0 & 0 & $\mathbf{0}$ & 0 & $\mathbf{0}$ \\
\hline 365 & 0 & 0 & 0 & 0 & 0 & 0 \\
\hline 396 & 0 & $\mathbf{0}$ & 0 & 0 & 0 & $\mathbf{0}$ \\
\hline 424 & 0 & 0 & 0 & 0 & 0 & 0 \\
\hline 455 & 0 & 0 & .40 & $\mathbf{0}$ & 0 & $\mathbf{0}$ \\
\hline 485 & 0 & 0 & .50 & $\mathbf{0}$ & 0 & $\mathbf{0}$ \\
\hline 516 & 0 & 0 & 1.1 & 0 & 0 & 0 \\
\hline 546 & 0 & 0 & 1.3 & 0 & 0 & 0 \\
\hline 577 & 0 & 0 & 1.3 & 0 & 0 & 0 \\
\hline 608 & 0 & 0 & 3.7 & 0 & 0 & 0 \\
\hline 638 & 0 & 0 & 3.7 & 0 & 0 & 0 \\
\hline 669 & 0 & 0 & 4.2 & 0 & 0 & 0 \\
\hline 699 & 0 & 0 & 4.7 & 0 & 0 & 0 \\
\hline 730 & 0 & 0 & 4.7 & 0 & 0 & 0 \\
\hline
\end{tabular}


Table 15. Results of leaching simulations--Continued

\begin{tabular}{|c|c|c|c|c|c|c|}
\hline \multirow[b]{3}{*}{$\begin{array}{c}\text { Day (from Jan. } \\
1, \text { first year) }\end{array}$} & \multicolumn{6}{|c|}{$\begin{array}{l}\text { Atrazine concentrations in soil water in silty loam, in micrograms per } \\
\text { liter }\end{array}$} \\
\hline & \multicolumn{2}{|c|}{$\begin{array}{c}\text { Near-normal } \\
\text { precipitation ( } 37.64 \\
\text { inches) }\end{array}$} & \multicolumn{2}{|c|}{ 12-inch chemigation } & \multicolumn{2}{|c|}{ 32-inch chemigation } \\
\hline & $\begin{array}{l}\text { 6-foot } \\
\text { depth }\end{array}$ & $\begin{array}{l}\text { 16-foot } \\
\text { depth }\end{array}$ & $\begin{array}{l}\text { 6-foot } \\
\text { depth }\end{array}$ & $\begin{array}{l}\text { 16-foot } \\
\text { depth }\end{array}$ & $\begin{array}{l}6 \text {-foot } \\
\text { depth }\end{array}$ & $\begin{array}{l}\text { 16-foot } \\
\text { depth }\end{array}$ \\
\hline 119 & $\mathbf{0}$ & $\mathbf{0}$ & $\mathbf{0}$ & $\mathbf{0}$ & $\mathbf{0}$ & $\mathbf{0}$ \\
\hline 151 & $\mathbf{0}$ & 0 & 0 & $\mathbf{0}$ & $\mathbf{0}$ & $\mathbf{0}$ \\
\hline 181 & $\mathbf{0}$ & 0 & .01 & $\mathbf{0}$ & .02 & 0 \\
\hline 210 & $\mathbf{0}$ & 0 & .63 & $\mathbf{0}$ & 11 & .04 \\
\hline 243 & $\mathbf{0}$ & $\mathbf{0}$ & 1.8 & $\mathbf{0}$ & 58 & .60 \\
\hline 273 & $\mathbf{0}$ & $\mathbf{0}$ & 2.0 & 0 & 59 & .64 \\
\hline 304 & .01 & $\mathbf{0}$ & 2.6 & 0 & 65 & .77 \\
\hline 334 & .02 & 0 & 3.1 & 0 & 70 & .90 \\
\hline 365 & .02 & $\mathbf{0}$ & 3.3 & 0 & 70 & .93 \\
\hline 396 & .03 & 0 & 3.4 & 0 & 69 & .94 \\
\hline 424 & .06 & 0 & 4.4 & 0 & 76 & 1.1 \\
\hline 455 & 1.0 & 0 & 14 & .03 & 120 & 3.0 \\
\hline 485 & 1.4 & 0 & 16 & .04 & 120 & 3.4 \\
\hline 516 & 3.2 & 0 & 25 & .08 & 140 & 5.3 \\
\hline 546 & 4.2 & 0 & 46 & .31 & 220 & 25 \\
\hline 577 & 4.6 & 0 & 93 & 1.9 & 250 & 83 \\
\hline 608 & 11 & 0 & 120 & 3.7 & 240 & 120 \\
\hline 638 & 12 & 0 & 120 & 3.9 & 230 & 120 \\
\hline 669 & 14 & .01 & 120 & 4.5 & 220 & 120 \\
\hline 699 & 16 & .01 & 120 & 5.1 & 210 & 120 \\
\hline 730 & 17 & .02 & 120 & 5.2 & 200 & 120 \\
\hline
\end{tabular}


Table 15. Results of leaching simulations--Continued

\begin{tabular}{|c|c|c|c|c|c|c|}
\hline \multirow[b]{3}{*}{$\begin{array}{l}\text { Day (from Jan. } \\
1, \text { first year) }\end{array}$} & \multicolumn{6}{|c|}{$\begin{array}{l}\text { Atrazine concentrations in soil water in sandy loam, in micrograms } \\
\text { per liter }\end{array}$} \\
\hline & \multicolumn{2}{|c|}{$\begin{array}{c}\text { Near-normal } \\
\text { precipitation ( } 37.64 \\
\text { inches) }\end{array}$} & \multicolumn{2}{|c|}{ 12-inch chemigation } & \multicolumn{2}{|c|}{ 32-inch chemigation } \\
\hline & $\begin{array}{l}\text { 6-foot } \\
\text { depth }\end{array}$ & $\begin{array}{l}\text { 16-foot } \\
\text { depth }\end{array}$ & $\begin{array}{l}\text { 6-foot } \\
\text { depth }\end{array}$ & $\begin{array}{l}\text { 16-foot } \\
\text { depth }\end{array}$ & $\begin{array}{l}\text { 6-foot } \\
\text { depth }\end{array}$ & $\begin{array}{l}\text { 16-foot } \\
\text { depth }\end{array}$ \\
\hline 119 & 0 & 0 & 0 & 0 & 0 & 0 \\
\hline 151 & .24 & 0 & .08 & 0 & .08 & $\mathbf{0}$ \\
\hline 181 & .69 & 0 & 10 & 0 & 50 & $\mathbf{0}$ \\
\hline 210 & 1.0 & 0 & 130 & 0 & 500 & 66 \\
\hline 243 & 19 & 0 & 280 & .04 & 740 & 8.6 \\
\hline 273 & 24 & 0 & 300 & .04 & 710 & 9.2 \\
\hline 304 & 43 & 0 & 300 & .06 & 680 & 11 \\
\hline 334 & 63 & 0 & 380 & .07 & 640 & 13 \\
\hline 365 & 71 & 0 & 380 & .08 & 610 & 13 \\
\hline 396 & 76 & 0 & 380 & .08 & 580 & 13 \\
\hline 424 & 120 & $\mathbf{0}$ & 420 & .12 & 530 & 16 \\
\hline 455 & 330 & 0 & 560 & .69 & 390 & 36 \\
\hline 485 & 360 & 0 & 560 & .86 & 350 & 40 \\
\hline 516 & 430 & .03 & 540 & 1.8 & 260 & 57 \\
\hline 546 & 430 & .04 & 450 & 6.2 & 160 & 170 \\
\hline 577 & 420 & .06 & 380 & 27 & 540 & 290 \\
\hline 608 & 400 & .28 & 430 & 49 & 700 & 300 \\
\hline 638 & 380 & .34 & 420 & 51 & 680 & 290 \\
\hline 669 & 360 & .50 & 440 & 57 & 660 & 280 \\
\hline 699 & 340 & .68 & 460 & 63 & 640 & 260 \\
\hline 730 & 330 & .76 & 420 & 63 & 610 & 250 \\
\hline
\end{tabular}


Table 15. Results of leaching simulations --Continued

\begin{tabular}{|c|c|c|c|c|c|c|}
\hline \multirow[b]{3}{*}{$\begin{array}{c}\text { Day (from Jan. } \\
1, \text { first year) }\end{array}$} & \multicolumn{6}{|c|}{ Atrazine concentrations in soil water in clay, in micrograms per liter } \\
\hline & \multicolumn{2}{|c|}{$\begin{array}{c}\text { Near-normal } \\
\text { precipitation ( } 37.64 \\
\text { inches) }\end{array}$} & \multicolumn{2}{|c|}{ 12-inch chemigation } & \multicolumn{2}{|c|}{ 32-inch chemigation } \\
\hline & $\begin{array}{l}\text { 6-foot } \\
\text { depth }\end{array}$ & $\begin{array}{l}\text { 16-foot } \\
\text { depth }\end{array}$ & $\begin{array}{l}\text { 6-foot } \\
\text { depth }\end{array}$ & $\begin{array}{l}\text { 16-foot } \\
\text { depth }\end{array}$ & $\begin{array}{l}\text { 6-foot } \\
\text { depth }\end{array}$ & $\begin{array}{l}\text { 16-foot } \\
\text { depth }\end{array}$ \\
\hline 119 & $\mathbf{0}$ & $\mathbf{0}$ & 0 & 0 & 0 & 0 \\
\hline 151 & 0 & 0 & 1 & 0 & 0 & 0 \\
\hline 181 & 0 & 0 & 0 & 0 & .10 & 0 \\
\hline 210 & 0 & 0 & .41 & 0 & 7.8 & .03 \\
\hline 243 & 0 & 0 & 1.2 & 0 & 45 & .04 \\
\hline 273 & 0 & 0 & 1.3 & 0 & 46 & .50 \\
\hline 304 & 0 & 0 & 1.8 & 0 & 52 & .57 \\
\hline 334 & 0 & 0 & 2.2 & 0 & 56 & .67 \\
\hline 365 & .01 & 0 & 2.3 & 0 & 56 & .69 \\
\hline 396 & .02 & 0 & 2.3 & 0 & 56 & .70 \\
\hline 424 & .04 & 0 & 3.1 & 0 & 60 & .87 \\
\hline 455 & .69 & 0 & 10 & .02 & 100 & 2.3 \\
\hline 485 & .93 & 0 & 12 & .03 & 100 & 2.6 \\
\hline 516 & 2.3 & 0 & 19 & .06 & 130 & 4.1 \\
\hline 546 & 3.0 & 0 & 37 & .23 & 210 & 21 \\
\hline 577 & 3.4 & 0 & 81 & 1.4 & 260 & 74 \\
\hline 608 & 8.8 & 0 & 110 & 3.0 & 250 & 110 \\
\hline 638 & 9.3 & 0 & 110 & 3.1 & 240 & 110 \\
\hline 669 & 11 & 0 & 110 & 3.6 & 230 & 110 \\
\hline 699 & 13 & 0 & 120 & 4.1 & 220 & 110 \\
\hline 730 & 14 & .01 & 110 & 4.2 & 210 & 110 \\
\hline
\end{tabular}


Table 15. Results of leaching simulations--Continued

Herbicide concentrations in soil water in silty loam (normal precipitation), in micrograms per liter

\begin{tabular}{|c|c|c|c|c|c|c|c|c|c|c|}
\hline \multirow{2}{*}{$\begin{array}{c}\text { Day } \\
\text { (from } \\
\text { Jan. 1, } \\
\text { first year) }\end{array}$} & \multicolumn{2}{|c|}{ Alachlor } & \multicolumn{2}{|c|}{ Atrazine } & \multicolumn{2}{|c|}{ Metolachlor } & \multicolumn{2}{|c|}{ Trifluralin } & \multicolumn{2}{|c|}{$2,4-\mathrm{D}$} \\
\hline & $\begin{array}{l}\text { 6-foot } \\
\text { depth }\end{array}$ & $\begin{array}{l}\text { 16-foot } \\
\text { depth }\end{array}$ & $\begin{array}{l}\text { 6-foot } \\
\text { depth }\end{array}$ & $\begin{array}{l}\text { 16-foot } \\
\text { depth }\end{array}$ & $\begin{array}{l}\text { 6-foot } \\
\text { depth }\end{array}$ & $\begin{array}{l}\text { 16-foot } \\
\text { depth }\end{array}$ & $\begin{array}{l}\text { 6-foot } \\
\text { depth }\end{array}$ & $\begin{array}{l}\text { 16-foot } \\
\text { depth }\end{array}$ & $\begin{array}{l}\text { 6-foot } \\
\text { depth }\end{array}$ & $\begin{array}{l}\text { 16-foot } \\
\text { depth }\end{array}$ \\
\hline 119 & 0 & 0 & 0 & 0 & 0 & 0 & 0 & 0 & 0 & 0 \\
\hline 151 & 0 & 0 & 0 & 0 & .02 & 0 & 0 & 0 & 0 & 0 \\
\hline 181 & 0 & 0 & 0 & 0 & .05 & 0 & 0 & 0 & 0 & 0 \\
\hline 210 & 0 & 0 & 0 & 0 & .07 & 0 & 0 & 0 & 0 & 0 \\
\hline 243 & .20 & 0 & 0 & 0 & 1.1 & 0 & 0 & 0 & 0 & 0 \\
\hline 273 & .25 & 0 & 0 & 0 & 1.4 & 0 & 0 & 0 & 0 & 0 \\
\hline 304 & .47 & 0 & .01 & 0 & 2.3 & 0 & 0 & 0 & 0 & 0 \\
\hline 334 & .73 & 0 & .02 & 0 & 3.2 & 0 & 0 & 0 & 0 & 0 \\
\hline 365 & .83 & 0 & .02 & 0 & 3.5 & 0 & 0 & 0 & 0 & 0 \\
\hline 396 & .89 & 0 & .03 & 0 & 3.7 & 0 & 0 & 0 & 0 & 0 \\
\hline 424 & 1.6 & 0 & .06 & 0 & 5.5 & 0 & 0 & 0 & 0 & 0 \\
\hline 455 & 9.9 & 0 & 1.0 & 0 & 15 & .07 & 0 & 0 & 0 & 0 \\
\hline 485 & 12 & .01 & 1.4 & 0 & 16 & .10 & 0 & 0 & 0 & 0 \\
\hline 516 & 18 & .05 & 3.2 & 0 & 18 & .30 & .02 & 0 & 0 & 0 \\
\hline 546 & 20 & .07 & 4.2 & 0 & 17 & .40 & .04 & 0 & 0 & 0 \\
\hline 577 & 20 & .08 & 4.6 & 0 & 16 & .45 & .04 & 0 & 0 & 0 \\
\hline 608 & 29 & .32 & 11 & 0 & 15 & 1.4 & .12 & 0 & 0 & 0 \\
\hline 638 & 28 & .35 & 12 & 0 & 14 & 1.4 & .12 & 0 & 0 & 0 \\
\hline 669 & 28 & .47 & 14 & .01 & 13 & 1.8 & .16 & 0 & 0 & 0 \\
\hline 699 & 28 & .58 & 16 & .01 & 12 & 2.0 & .20 & 0 & 0 & 0 \\
\hline 730 & 26 & .61 & 17 & .02 & 12 & 2.1 & .20 & 0 & 0 & 0 \\
\hline
\end{tabular}


increased from $R=0$ to $R=0.51$

Simulated concentrations of the herbicide atrazine with a half-life of 150 days were generated using the method of including the silt fraction in the sand fraction. These concentrations were compared to observed concentrations in soil water in the silty loam, sandy loam, and the clay. The correlation between the observed atrazine concentrations and the simulated concentrations was $R=0.42$. Next, an adjustment in the herbicide halflife with depth was included in the simulations. A 150-day half-life was used at the surface layer, but below the surface layer, the value was increased until a half-life of 1,000 days was reached. This adjustment improved the calibration, but a final adjustment was needed. The best match with the observed data was finally achieved by adjusting the organic-carbon content of the soil. The organic-carbon content was multiplied by 0.1 . With this adjustment, the calibrated-to-observed correlation was increased to $\mathbf{R}=\mathbf{0 . 6 2}$ for all sites and observed depths.

The PRZM was best calibrated to the observed data by coding the sand-and-silt fraction as sand, multiplying the organic-carbon content by 0.1 , and increasing the half-life of the herbicide to the maximum published value. These adjustments are simple and can be justified as corrections in the unsaturated flow regime for macropore flow and increasing the half-life of the herbicide with depth and degree of saturation. These adjustments to the input data for the PRZM enabled the model to better simulate herbicide movement through the unsaturated zone to a shallow aquifer.

Simulations of herbicide movement and distribution were made for a 2-year period with the calibrated model under various hypothetical conditions. Simulations were made using the three soil types under one-half near-normal, near-normal, and twice near-normal annual precipitation. Simulations were made with normal and twice-normal atrazine-application rates. Chemigation was simulated by applying one-third of the atrazine at planting, and the remaining two-third on two other occasions when irrigation water was applied. Two amounts of irrigation application were simulated--12 and 32 inches of water. Finally, four different herbicides with varying solubility and half-lives were simulated for comparison.

Simulations of atrazine transport in soil water for the three soil types using an annual precipitation total of 37.64 inches showed very little atrazine leaching in soil water to the 6-foot depth in the silty loam and clay. However, the sandy loam showed significant leaching the first year, with increasing concentrations the following year. At the 16-foot depth, the sandy loam showed a rapid increase the second year. When precipitation was decreased by 50 percent, there was virtually no leaching of atrazine in any soil. When precipitation was doubled, the leaching increased by one order of magnitude. When the atrazine-application rate was doubled, the quantity of leached atrazine doubled. Doubling precipitation (or applied water in irrigation) is much more critical to leaching than doubling the herbicide-application rate.

A similar response was observed in the model simulations of chemigation. Even though the application of 12 inches of irrigation water represented a 32-percent increase in water for leaching, atrazine concentrations in soil water increased an average of 5.6 times for the three soil types at the 6-foot depth after 2 years. At the 16-foot depth, the increase was greater than two orders of magnitude.

Leached concentrations in soil water for four other herbicides were simulated for silty loam at the 6-foot depth and near-normal precipitation. 2,4-D, which has a small solubility and a short half-life, did not leach to 6 feet. A trace of trifluralin $(0.20 \mu \mathrm{g} / \mathrm{L})$ leached to the 6foot depth after 2 years of simulation. Solubility for trifluralin is small, but its half-life under near-saturated conditions was estimated to be almost that of alachlor and metolachlor. Larger quantities of atrazine were leached because of its increased solubility and longer half-life. Atrazine concentrations were slow to increase at 6 feet the first year but continued to increase throughout the 2-year simulation. Alachlor concentrations increased more quickly than the atrazine but not as quickly as the metolachlor, which is the most soluble of the five herbicides simulated. The simulated alachlor concentrations were slower to increase than those for metolachlor, but the longer half-life of alachlor allowed it to reach a larger concentration, nearly twice that of the 
metolachlor.

Results of observations and modeling revealed the extent and potential of herbicide leaching for three different soil types under various conditions. Decay rates of the five herbicides were estimated by analysis of soil water or soil cores. The Pesticide Root Zone Model (PRZM) was calibrated with observed data from the leaching experiments. However, major adjustments to the input data were required. These adjustments were: (1) Including the silt fraction in the sand fraction; (2) decreasing the apparent organic-carbon content of the soil by multiplying the observed content by 0.1 ; and (3) increasing the half-life of the herbicide in question to at least the maximum published value. These same adjustments also will be necessary in utilizing the "Leaching Evaluation of Agricultural Chemicals Handbook" (LEACH) for locations in Kansas.

\section{REFERENCES}

Abmeyer, Walter, and Campbell, H.V., 1970, Soil survey of Shawnee County, Kansas: U.S. Department of Agriculture Soil Conservation Service, $77 \mathrm{p}$.

Carsel, R.F., Smith, C.N., Mulkey, L.A., Dean, J.D., and Jowise, Peter, 1984, Users manual for the Pesticide Root Zone Model (PRZM), Release 1: U.S. Environmental Protection Agency, Environmental Research Laboratory, Athens, Georgia, EPA-600/3-84-109, 216 p.

Dean, J.D., Jowise, P.P., and Donigian, A.S., Jr., 1984, Leaching evaluation of agricultural chenicals (LEACH) handbook: U.S. Environmental Protection Agency, Environmental Research Laboratory, Athens, Georgia, EPA-600/3-84-068, 407 p.

Enfield, C.G., and Carsel, R.F., 1980, Mathematical prediction of toxicant transport through soil, in Test protocols for environmental fate and movement of toxicants: Proceedings of Symposium, Association of Official Analytical Chemistry, p. 233-250.
Fader, S.W., 1974, Ground water in the Kansas River valley, Junction City to Kansas City, Kansas: Kansas Geological Survey Bulletin 206, part 2, 12 p.

Farnsworth, R.K., Thompson, E.S., and Peck, E.L., 1982, Evaporation atlas for the contiguous 48 United States: U.S. Department of Commerce, National Oceanic and Atmospheric Administration Technical Report NWS 33, 26 p.

National Oceanic and Atmospheric Administration, 1989, Climatological data, annual summary, Kansas 1989: Asheville, North Carolina, National Climatic Center, v. 103, no. 13, 42 p.

Penman, H.L., 1948, Natural evaporation from open water, bare soil and grass: Proceeding of Royal Society of London, series A, v. 193, p. 120-145.

Perry, C.A., 1990, Source, extent, and degradation of herbicides in a shallow aquifer near Hesston, Kansas: U.S. Geological Survey Water-Resources Investigations Report 90-4019, 24 p.

Perry, C.A., Eiden, Catherine, Barnes, P.L., and Tessari, John, in press, Some guidelines for onsite studies of pesticide leaching in the unsaturated and saturated zones: U.S. Geological Survey Water-Resources Investigations Report 91-4075.

Perry, C.A., Robbins, F.V., and Barnes, P.L., 1988, Factors affecting leaching in agricultural areas and an assessment of agricultural chemicals in the ground water of Kansas: U.S. Geological Survey Water-Resources Investigations Report 88-4104, 55 p.

Sophocleous, M.A., and Perry, C.A., 1985, Experimental studies in natural groundwater recharge dynamics--The analysis of recharge events: Journal of Hydrology, v. 81, p. 297-332. 


\section{SUPPLEMENTAL INFORMATION}

Root-mean-square (RMS) computations for chloride and atrazine concentrations in soil water for three soil types and four depths are given in table 16. For these 24 groups, 12 for the chloride and 12 for atrazine, all 12 of the chloride computations showed improvement (decrease in the RMS value) after adjusting the Pesticide Root Zone Model (PRZM) by treating the sand-and-silt fraction as sand. For atrazine, four RMS values decreased, three stayed the same, and five values of RMS increased after adjusting the PRZM by treating the sand-and-silt fraction as sand and adjusting the organiccarbon content by a factor of 0.1 . However, RMS values for the soils with the most clay and silt were smaller than for the sandy soil. This does not mean that there was a better fit or calibration between the observed and simulated values for the clay or silty soils. Instead, the smaller RMS values were a result of the model producing concentrations of 0 , while the observed values were small, say $0.40 \mu \mathrm{g} / \mathrm{L}$. The RMS between these values is quite small. In these cases, the model failed to leach any chemical beyond the surface layer. The smallest RMS values would result when the model did not leach any chemical, therefore making the RMS an unsatisfactory measure of calibration. At the other extreme, the sandy soil simulations produced concentrations that were at least in the same order of magnitude. However, the RMS values were quite large when a simulated concentration of $100 \mu \mathrm{g} / \mathrm{L}$ was compared with an observed concentration of $200 \mu \mathrm{g} / \mathrm{L}$.

Correlations between observed and simulated values were made for all soil types and depths to improve the measurement of the PRZM response to different soils and depths. A primary use of PRZM is to determine which soils and environmental conditions will result in the greatest leaching of herbicides. The soil profiles with the least amount of leaching had the smallest RMS values, whereas the most leaching soil profiles had the largest RMS values. By grouping all depths and soils into one large set for correlation, the effect of altering one parameter could be collectively evaluated.

The correlations and the RMS values supplied are from observed values for specific dates, and simulated values were determined by interpolation between end-of-month values during a 2-year period. 
Table 16. Root-mean-square computations between observed and simulated chloride and atrazine concentrations in soil water for three soil types and four depths

\begin{tabular}{lcc}
\hline & \multicolumn{2}{c}{ Chloride concentration in milligrams per liter } \\
\cline { 2 - 3 } Soil type and depth & $\begin{array}{c}\text { Root mean square } \\
\text { (RMS), unadjusted }\end{array}$ & $\begin{array}{c}\text { Root mean square } \\
\text { (RMS), silt-to-sand } \\
\text { adjustment }\end{array}$ \\
\hline Silty loam & & 371 \\
2 feet & 425 & 403 \\
3 feet & 450 & 424 \\
4 feet & 467 & 16 \\
6 feet & 26 &
\end{tabular}

Sandy loam

$\begin{array}{lll}2 \text { feet } & 565 & 519 \\ 3 \text { feet } & 407 & 356 \\ 4 \text { feet } & 375 & 327 \\ 6 \text { feet } & 210 & 181\end{array}$

Clay

2 feet $\quad 197 \quad 163$

3 feet $243 \quad 214$

4 feet $279 \quad 263$

6 feet $\quad 33 \quad 29$

Correlation $\quad 0.51$

coefficient 